588

B 73

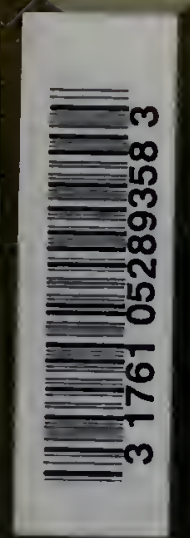




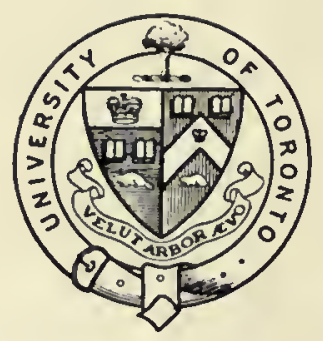

Presented to the

UNIVERSITY OF TORONTO LIBRARY

by the

ONTARIO LEGISLATIVE LIBRARY

1980 

Digitized by the Internet Archive in 2008 with funding from Microsoft Corporation 
THE

SPHAGNACEE OR PEAT-MOSSES

oF

EUROPE AND NORTH AMERICA. 

THE SPHAGNACE OR

\section{PEAT-MOSSES}

OF

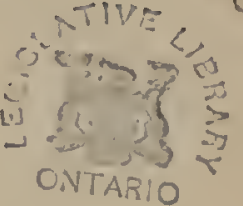

EUROPE AND NORTH AMERICA.

BY

R. BRAITHWAITE, M.D., F.L.S., ETc., SOC. CORRISP, DELIA SOCIETA CRITTOGAMOLOGICA ITALIANA.

"Muscus hic nulli ex terrestribus similis est, sed faciem habet propriam, nec alibi quam in udis at paludosis nascitur."-DILLEN.

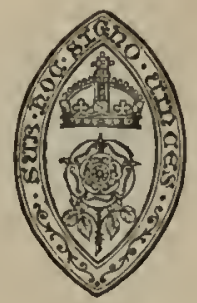

L O N D O N

DAVID BOGUE, 3, ST. MARTI SPACE, W. E. I 880 . 

TO

\section{THE ROYAL MICROSCOPICAL SOCIETY}

\section{THIS WORK}

IS RESPECTFULLY DEDICATED,

BY THEIR OBEDIENT SERVANT,

THE AUTHOR. 



\section{P R E FACE.}

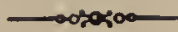

THE papers on which this work is founded were originally communicated to the Royal Microscopical Society, at the request of one of my friends on the Council ; and it is, therefore, with peculiar pleasure I dedicate it to them, since without the instrument which they have done so much to bring to perfection, no satisfactory investigation of the subject would be possible.

As I have been only able to prosecute it as a relaxation from active professional work, I am aware it must exhibit many deficiencies and shortcomings; yet the dissections and observations required, have proved to me lessons of the highest value in imparting a knowledge of these interesting plants, which I trust may to some extent be shared in by all who make use of this record of them.

The drawings of the plants are all of the natural size, and taken from specimens in a moist or expanded state; the dissections have as far as possible been copied by means of the camera lucida and Messrs. Beck's large instrument with 3 -inch and $\frac{2}{3}$-inch objectives, and represent the structural peculiarities which are characteristic of the different species.

To Professor Lindberg, of Helsingfors, I am deeply indebted for rare specimens and critical observations, and to him and the various correspondents whose names are recorded under each species, I beg to offer my warmest thanks.

Clapham Rise, LoNdon,

September, 1878 . 



\title{
THE SPHAGNACEÆ OR PEAT-MOSSES
}

\author{
OF \\ EUROPE AND NORTH AMERICA.
}

CHAPTER I.

LITERATURE OF THE GENUS SPHAGNUM.

The name $\sigma \phi \alpha \gamma \nu$ os was first used by the ancient botanists, Theophrastus, Dioscorides, and Pliny, to indicate certain species of Salvia and Lichen; but as a genus of mosses Sphagnum was established by Dillewius in his first work, Catalogus Plantamu sponte circa Gissam nascentium (I719), though not in the restricted sense as now understood, since he included in it various other mosses which had no evident pedicels, as Grimmia apocarpa, Hedwigia ciliata, Cryphaa, \&c.

Before his time, however, Lobel had figured a true speciesS. acutifolium-in his Icones Stirpium, ii. p. 242 (I59I), under the name of Muscus terrestris vulgaris; and a century later PLuKenet figured S. cymbifolium, in his Phytographia, as Muscus palustris in ericetis nascens floridus, and VAILlaNt, in his Botanicon Parisiense ( 1727 ), also gives figures of the same.

Dillenius, in the third edition of Ray's Synopsis Stirpium Britannicarnm (1724), adopts the genus, with the observation, "This moss is like none of the terrestrial, but has a peculiar aspect, nor is it produced anywhere else but in bogs and marshes." In his celebrated Historia Muscorum (I741) he introduced sixteen species of Sphagnum, but the only genuine are $S$. palustre molle deflexum, squamis cymbiformibus $=S$. cymbifolium, and $S$. palustre molle deflexum, squamis capillaceis with a var. $\beta$ fuitans $=S$. acutifolium + cuspidatum.

Linneus, in his Species Plantarum (1753), still retained Cryphaca heteromalla as Sphagnum arboreum, and recognized only 
one other species, which he named $S$. palustre, with a var. $\beta$, and under this he included all the true species of the family.

Ehrhart clearly defined the genus, and established as species S. cymbifolium, acutifolium, and cuspidatum, in the Hannoverisches Magazin (1 780), and Plante Crypt. Exsicc. ( 785 ).

Hedwig, in his Fundamenta Muscomm (1782), characterized the genus, and gave most beautiful figures of the fruit and antheridia, the latter being then made known for the first time.

BRIDEL described several species in the Muscologia Recentiorum (I 797), and in his Mantissa (1819) extends the number to fourteen, six being European.

Schwaegrichen, in Suppl. I. to Hedwig's Species Mruscorum, figures Sph. cuspidatum, compactum, and squarrosum.

P. DE BEAuvols gives a good natural character of the genus in a paper on Muscology, in Ménoires de la Société Linnécnne, Paris, 1822 , and notices the peculiar areolation of the leaves as serving to distinguish them from all other mosses.

N. von ESENBECK and HoRnschuci, in the Bryologia Germanica, vol. i. (1823), describe nine species of Sphagnum, but two of these are only varieties; and figures are given of thirteen species and varieties.

Bridel, in his last work, Bryologia Universa (1826), added the natural characters of the genus to the description he had previously given, and pointed out its distinctness from all others.

J. Hegetschweiler contributed a paper, Revision des Genus Sphagnum, to the Denkschriften der Schweizer Gesells. für gesam. Naturwiss., Zurich, 1829, in which he looks upon the species of Sphagnum as so variable, that he refers all the forms to a broadleaved and a narrow-leaved species, just as they were originally placed by Dillenius.

FürnRonr, in the Regensburg Botanische Zeitung for I 833, gave a paper, Versuch ciner Lebens- und Formgeschichte der Gattung Sphagnum, but it is only a résumé of the work of previous writers.

C. Müller, in his valuable Synopsis Muscorum Frondosonm (1846), formed a tribe Sphagnacea, and gives full descriptions of seventeen species, but speaks of the leaves having intercellular ducts; he also describes the cells as inanes or replcte, according to the presence or absence of spiral threads, and uses this as an important character in the distinction of species, though we now know that really little stress can be laid upon it; yet that this 
learned author thinks otherwise, is evident by his description of new species in a recent number of Linnea, where the same form of diagnosis is followed.

Wilson, in the Bryologia Britannica (1855), gives an excellent outline of the characters peculiar to the Sphagna, and describes nine species as British.

Sullivant, in his Musci and Hepatice of the United States (1856), describes sixteen species and indicates four others as European; several of these, however, are only varieties.

Moldenhawer, in his Beiträge zur Anatomie der Pfanzen (1812), first pointed out the dimorphous character of the cells composing the leaves of the Sphagnacex, and Vov MonL investigated and confirmed these views in a valuable paper, Anatomische Untersuchungen über die porösen Zellcn von Sphagnum (1854); while C. NäGELI minutely studied the process of development of the stem and leaves, and published the result in Zeitschrift für wissenschaftliche Botanik, Heft 2 (1845).

DOZY gives an exact account of the anatomy of the Sphagna, in his Bijdragen tot de Anatomie en Phytographie van de Sphagna (1854), with good drawings of their structure.

Hofmeister has ably investigated the minute development of the Sphagna, and especially the structure of the female organ and first formation of the fruit. See his Vergleichende Untersuchungen, \&c. (185I).

SCHIMPer, in $185^{8}$, gave to the world his grand treatise on this subject, Versuch einer Entwickelungs-geschichte der Torfmoose, a work most complete in details of structure both descriptive and pictorial, and leaving hardly anything to be desired. In it he advocates the elevation of the Sphagna to the dignity of a class, equal to those of Mosses and Hepaticæ, but in the new edition of his Synopsis Muscorum he ranks them as anomalous mosses. His descriptions of species are a model for all authors; the habit of the plant, the external form and internal structure of the stem, and of the leaves of the stem, branches, and perichætium, all find a place in the diagnostic characters.

Lindberg, in vol. xix. of Öfvers. K. Vetensk. Akad. Förhandl. (1 862), published a paper, Torfmossornas byggnad Ctbredning och systematiska Uppställning, in which will be found some valuable observations on the family, and a mode of grouping the species nearly the same as that adopted in the present work. 
Russow, in 1865, gave us his Beiträge zur Kenntniss der Torfmoose, containing some excellent observations on their histology, and notes on the various species and varieties, which display an intimate practical acquaintance with these plants. . He insists on the inconstancy of the monoicous or dioicous character of the inflorescence, and hence reduces the number of species.

Schliephacke, in Verhandl. Zool. Bot. Gesells. Wien, vol. xv. p. 383 (1865), has also a good paper on the subject, Beiträge zur Kenntniss der Sphagna, with clear and valuable notes on distinction of species, and their variations.

M. Piré, in Bull. de la Soc. royale de Bot. de Belgique, t. vi. n. 3 (1 868), gives a short paper, Les Sphaignes de la Flore de Belgique, in which the result of his investigation of the Belgian species is recorded, accompanied by a very beautiful plate illustrating the structure of their leaves.

KLINGGRÄFF has an article on the Prussian species, in Schriften der Kön. Physikalisch-CEkon. Gesells. zu Königsberg, vol. xiii. p. I $(1872)$, in which several generally accepted varieties are raised to the rank of species, as he acts on the opposite view to that advocated by Russow, and insists on the stability of the characters founded on the monoicous or dioicous position of the inflorescence.

M. E. Roze, in Bull. de la Soc. Botan. de France, xix. p. 9 I (1872), gives an elaborate paper, De la Fécondation chez les Cryptogames supérieures, et en particulier chez les Sphaignes, in which he dissents from the opinion of Hofmeister that the canal in the neck of the archegonium is formed by dissolution of the central string of cells, and states that it pre-exists as a cavity in common with that of the body of the archegonium. Further observations are also given, detailing the actual mode of contact between the antherozoids and the germinative cell of the archegone.

DĚDEČEK, in Verhandl. der k. k. Zool. Bot. Gesells. Wien, vol. xxvi. p. 60I (1876), has an article, Die böhmischen Sphagna und ihre Gesellschafter, giving a list of the species, but principally interesting in enumerating all the mosses and Hepatica which are found growing associated with the Sphagna.

The above named are all the more important works or papers bearing on the subject, but numerous other articles or descriptions of species find a place in general works on mosses, or in the periodical literature of the day; these will be found quoted in the 
synonymy of each species, and all have been consulted as far as possible.

Various Exsiccata have also been published, in which the Sphagna are more or less completely represented, but the specimens are not in all cases correctly named; my Sphagnacea Britannice Exsiccatce will, I hope, remedy this, so far as the British species are concerned, as well as more effectually illustrate the forms described in the present work, though in this also a few errors have been detected, which will be corrected under each species described in the monograph.

A work to comprise all the Belgian forms-Sphagnotheca Belgica, by M. Gravet-is now in course of publication, but I have not had the opportunity of consulting it; neither have I been able to inspect the various continental herbaria, and thus place on record a more complete list of foreign localities; I have, however, made full use of the valuable papers published by Professor Lindberg, and gathered together stray notes met with in journals, in order as far as possible to extend our knowledge of the distribution of these plants. 


\section{CHAPTER II.}

\section{GENERAL OBSERVATIONS.}

The plants constituting the family Sphagnacea, and known as Peat-mosses or Bog-mosses, have long attracted notice from the ordinary observer by their peculiar aspect and habit, and have equally interested the microscopist by the beauty of their tissues, and exercised the botanist by the difficulty which attends their correct determination; the latter perhaps increased by the great variability of some species, and the uncertainty of the characters relied upon by various authors for the purpose of specific distinction.

No group of plants is more clearly defined in structure, in general family likeness, and in the localities in which they are found, for all are essentially Bog-mosses; yet as various true mosses are equally inhabitants of bogs, e.g. various Hypna, Aulacomnium palustre, Paludella, Meesea, \&c., I prefer to term them more definitely Peat-mosses, since on them alone the first formation of peat largely depends, and the name accords with that long recognized by the Germans, whose Laubmoose or frondose mosses, Torfmoose or Peat-mosses, and Lebermoose, Livermosses or Hepatica, thus form one great Muscal alliance.

Few persons can have traversed our moorlands without having had their attention attracted to the great masses of Sphagnum which adorn their surface-now in dense cushions of lively rednow covering some shallow pool with a vast sheet of light green, inviting it may be by its bright colour, but woe betide the inexperienced collector who sets foot thereon, for the spongy mass may be many feet in depth, and he may run the chance of never reaching terra firma again.

The plants always grow in this aggregated fashion, for the stems are weak and fragile, and they thus afford each other mutual support; and this fragility requires us to deal gently with our collections if we would have good herbarium specimens; the immense quantity of water they retain must be squeezed out carefully, and not by roughly grasping the tufts in the hand, other- 
wise the stems are sure to be broken; quick transference to the press, and a frequent change of drying paper, will usually ensure a satisfactory result.

We may point out to the tyro a few other characters by which our plants are distinguished from the true mosses. If we examine a single stem we find that the branches are in fascicles or clusters, i. e. spring several together from one point, and at the top are closely packed in a roundish head or coma; if we look at the leaves of one of these branches under the microscope, we find they consist of a network of large empty cells which contain threads winding spirally round on the interior of the membrane, and are bounded by a dark line of narrow cells filled with chlorophyl; the capsule also is sessile on the dilated end of a naked branch. For the determination of species, however, a more minute examination is necessary, as besides the form of the various leaves we also require a knowledge of their internal structure, as well as that of the stem; this is obtained by transverse sections of them, sufficiently thin to allow the light to be transmitted, and these are best examined in water and uncovered.

The simplest mode of making the sections is to enclose the wet stem or branches in a split vial cork and tie them tight, then with a razor to make very thin slices of the whole, placing them in a few drops of water on a slide, when they will immediately expand and the cork may be picked out with a needle. Russow recommends that the whole plant be soaked in thick mucilage and allowed to dry, and then cut with a razor into water. Certain reagents are also of use in the examination of cell structure, as iodine and sulphuric acid, or a solution of biniodide of zinc, by the action of which the Sphagnum leaf is coloured blue or reddish, and all its details of structure sharply defined. Heating the leaves on a slide in a little liquor sodx is of value in enabling us to obtain a clear view of the outline and condition of the walls of cells.

For those who have time and the necessary skill, the various parts may be mounted permanently on slides in glycerine, or other fluid suitable for vegetable tissues, and they then form very useful objects for comparison with any specimens which may be the subject of examination. * For the herbarium, it is better to separate the tufts into thin layers before submitting them to

* The Rev. Mr. Vize, of Forden Vicarage, Welshpool, has put up sets of the British Sphagna mounted in this manner. 
pressure, as the form and direction of the branches and leaves can thus be better seen.

Between fifty and sixty species of Sphagnum are known, of which about one-third are tropical; but they are most abundant in the north and south temperate zones, in the higher latitudes of which they cover a large expanse of surface.

Among the exotic species we may mention $S$. sericeum, C. Mürı., S. Holleanum, S. Funghuhnii, and S. Gedeanum, Dozy et MoLk., peculiar to the Eastern Archipelago, the two former only known in a barren state, but remarkable in having the stem leaves precisely like the branch leaves in form and structure, their hyaline cells being without fibres, but with a single apical pore.

Brazil is rich in forms, comprising S. erythrocalyx, perichatiale subrigidum, sparsum, and gracilescens of HAMPE, Caldense and pulchricoma, C. MülL.; and in Central America we find $S$. Negrense, limbatum, Mexicanum, and Peruvianum of Mitten, Meridense, C. Müll., longifolium, Mandon, subcuspidatum, Schimp. From Guadaloupe, S. Antillarum, C. Mülı., Guadalupense, Herminieri, and Husnoti, Schimp.; and from Australia and New Zealand, S. Mossmanni and cymbifolioides of C. MüLl., Australe, molliculum, antarcticum, confertum, and Novo-Zealandicum of MitTeN. The only species from Tropical Africa is $S$. Africanum, Duny. It would be desirable that all the exotic species should be submitted to a careful investigation and figured, although it would probably result in reducing their number, for each author appears to have set up a different standard in the characters regarded as specific.

With respect to the great variability in some species of Sphagnum, it is difficult to decide on any determining cause : soil certainly does not appear to exert any controlling influence, for we may often sce several varieties growing together in the same locality, but each preserving its proper character. The difference in the seasons, as regards moisture or drought, is probably an important factor in the question of development, size, or density; but the colour must be the result of vital action, since it depends on the colour of the chlorophyl deposited in the narrow cells of the leaves, which, shining through the transparent hyaline cells while moist, gives the beautiful and varied tints to the Sphagnum tufts while growing in their native habitats, and so imperfectly retained in dried specimens. Probably in all Sphagna we find a tendency to vary in two directions; the first and most marked 
of these is to form a compact or dense variety, by the shortening of the internodes, and consequent close approximation of the branch fascicles; this is well seen in such states as $S$. Austini var. imbricatum, S. papillosum var. confertum, S. cymbifolium var. congestum, $S$. rigidum var. compactum, and $S$. acutifolium var. arctum. The second is that in which the leaves of the branches which are normally straight and imbricated, exhibit a greater or less inclination to become squarrose; this does not render the plants so conspicuous as the last state, and is sometimes so slight as not to require indication by a special name; and even in cases where it may be quite evident, as in $S$. cymbifolium var. squarrosulum, we find intermediate forms which completely connect it with the type; nay, sometimes in the same tuft we may observe the leaves on plants at the circumference distinctly tending to squarrose, while those in the centre of the patch do not exhibit it at all; in this way it is quite possible to pick out the links that join $S$. teres to $S$. squarrosum.

In none do we find the range of variability so extensive as in S. acutifolium, and considerable experience is needed to identify satisfactorily all the forms of this protean plant. On this account we must, I think, rely on histological distinctions for the essential character of species, as size, colour, direction of leaves, habit, and presence or absence of fibres in the hyaline cells of the stem leaves, alike fail in this species to afford any stable grounds for the establishment of new ones, and the same considerations must guide us in dealing with the rest; they will thus stand on firm ground, and be more satisfactory to the true botanist than the most extensive series of phantom species.

The structures we must look upon as of most importance in affording specific distinctions are-

I. The number of cell strata composing the cuticle which invests the stem of the plant.

2. The stem leaves, with respect to their form, relation of the two kinds of cells, and structure of the apex.

3. The branch leaves, as to form, involution of margin, apex, relative position of the hyaline and chlorophyllose cells, and presence or absence of papillax on their internal lateral walls, and also the presence and size of the foramina. The number and direction of the branches in each fascicle, and nature of the retort cells of their cuticle, are also to be taken notice of. 
In following Professor Schimper in the separation of the Sphagnince as a sub-class from the Bryince or true frondose mosses, I can simply record my conviction that this is by far the most satisfactory mode of dealing with them, since they possess in their structure various peculiarities, which are not shared in by other mosses. It is to be regretted that this great bryologist has changed his views on this point, for in the second edition of his Synopsis he brings together the Archidiacea, Andrecacea, and Sphagnacea, as Bryince anomala, without supplying any character for the same, though it is clear that the only common bond of union is the large saccate calyptra, tearing open irregularly, and they thus correspond to Hampe's section Saccomitria.

The sub-class Sphagnince may be defined as follows:-

"Plants densely aggregated, without roots except in the young state. Stem with the axile cells soft, becoming indurated at the surface, clothed with a cuticle of one or several layers of large lax cells. Leaves nerveless, of a single stratum of dimorphous cells, the small utricular ones conveying sap and chlorophyl, enclosing the large, empty hyaline ones, which generally contain spiral fibres and have their walls perforated by large or small foramina. Inflorescence axillar, the male amentiform, antheridia globose, with very fine, branched paraphyses. Capsule globose, sessile on the apex of an elongated vaginula; calyptra saccate. Branches in lateral fascicles, aggregated at summit into a dense coma." This will comprise only a single family and a single genus-Sphagnum.

In no genus of frondose mosses do the branches occur in lateral fascicles springing from one point; nor do we find in any the peculiar dimorphous areolation of the leaves; the nearest to them in this respect as well as in external appearance is the family of Lencobryacea, but in their true structure they are totally different, and they equally stand apart by their antheridia and extraordinary paraphyses, and the loose cuticle investing their trunks.

As to the economic uses of the Sphagnacea, they are but small, except as a source of easily procured fuel; and in this respect indeed they are of immense importance, for no substitute could be found in the thinly populated and barren districts of the north, where trees become an insignificant object in the scenery, or cease to grow at all; yet nature, by the very means which produce 
these widely extended solitudes, supplies one of the first requirements of those who occupy them, and everywhere is peat annually cut, dried, and stored.

With regard to the function of these plants in the formation of peat, I cannot do better than quote Professor Schimper's words. He says :- "Unless there were peat-mosses, many a bare mountain ridge, many a high valley of the temperate zone, and large tracts of the northern plains, would present an uniform watery flat, instead of a covering of flowering plants or shady woods. For just as the Sphagna suck up the atmospheric moisture and convey it to the earth, do they also contribute to it by pumping up to the surface of the tufts formed by them, the standing water which was their cradle, diminish it by promoting evaporation, and finally also by their own detritus, and by that of the numerous other bog-plants to which they serve as a support, remove it entirely, and thus bring about their own destruction. Then, as soon as the plant-detritus formed in this manner has elevated itself above the surface water, it is familiar to us by the name of peat, becomes material for fuel, and all Sphagnum vegetation ceases."

Their power of retaining moisture renders them useful to the gardener in the cultivation of orchids, ferns, and other delicate plants, and for their package and transport in a fresh state.

But to the inquiring mind the study of the structure of these plants must prove an unfailing source of instruction, for in no members of the vegetable kingdom do we find means so well adapted to the ends they serve, as in the beautiful and varied tissues which build up a single stem of Sphagnum. 


\section{CHAPTER III.}

THE VEGETATIVE SYSTEM.

Germination of the Spore.

To the investigations of Nägeli and Hofmeister are we principally indebted for our knowledge of the development of the plant, and Professor Schimper further observed them under cultivation, and found that on damp earth the spores germinated in two to three months, and that the proembryonal cell rarely broke through the exospore or outer coat in less than five weeks.

The development proceeds under one of two forms, according to the local conditions in which the spores may happen to be placed at the time; thus, if they be immersed in water, the germinating proembryo assumes the form of a confervoid protonema, somewhat akin to that of true mosses, but more elongated and less branched; from one end of this the young plant arises by a tuberculoid aggregation of cells, while the other extremity becomes a root, or one of the middle cells becomes the mother cell of the new plant. But if the spore germinate on the damp ground, the proembryonal cell goes on subdividing in a horizontal plane, and the result is a lobed green prothallium like that of Equisetum, con-sisting of a single layer of cells; this hepaticine frond throws out radicles from the under surface and margins of the lobes, and quite resembles a plant of Blasia or Anthoceros. After a while, cells aggregate here and there at the margins of the lobes and form rudimentary plants, which support themselves partly from the prothallium, partly by radicles; in the plants growing in water also, the radicles attach themselves to any fixed body, and thus securely anchor the plants until they are in a condition to take care of themselves.

The roots in the young plants of Sphagnum precisely resemble those of frondose mosses, consisting of slender elongated cells with oblique transverse septa, and their functions are also similar, for they serve both for support and nutrition; as soon, however, as the branches are produced, a portion of them become pendent and 
appressed to the stem, and these with the spongy cuticle of the stem are far more effective than the roots for the transmission of fluid, while the dense masses formed by the aggregation of stems equally supersede the necessity for roots as fixing organs; these, therefore, being no longer needed, wither away and completely disappear.

\section{The Stem.}

The young stem appears from the under side of the prothallium by a change in the cell formation, some of the cells developing downwards into hair-like radicles, while the upper cell elongates and subdivides to form the young stemlet, some of the cells also becoming free laterally to form the rudimentary leaves; it is at first transparent, but soon acquires chlorophyl granules, and a differentiation into its cell layers is distinguishable at a very early stage.

When the young stem has attained a height of $5 \mathrm{~mm}$. it throws off at the sides simple flagellar branches, which arise laterally to the uppermost leaves, and are at first crowded in the coma and separate by elongation of the internodes. The branches come off at every fourth leaf as an obtuse bud, on which, when it has attained a height of three cells, leaves also form and division into branches takes place.

The growing point of the stem is conical, its terminal cell apparently subdividing in five directions, and thus continually elongating the stem; by longitudinal division and transverse extension of newly formed cells, the terminal cone thickens from above downward, and the base constantly forming anew attains the diameter of the already completed stem.

The trunk or perfectly developed stem consists of a simple primary axis with numerous terminal shoots enclosing the central terminal bud, and also of several secondary axes; for each year a lateral shoot is formed beneath the growing point, which is an exact repetition of the original main stem, with which it keeps a perfectly parallel advance in growth and development; in fact, it is nothing else but one of the fascicled lateral branches transformed into an ascending axis, and this again repeats the process the following season, so that we thus obtain not only the dense dichotomous ramification, but the fastigiate surface so characteristic of a cushion of Sphagmum plants.

Professor Schimper in his great work described the stem as 
constituted of three distinct cell formations, viz. a central pith, an intermediate woody cylinder, and an external bark, though, of course, these cannot correspond to the parts so named in higher plants; it seems, however, more appropriate to regard the stem of Sphagnum as consisting of a cylinder, the cells of which are soft and succulent in the centre, but become indurated and coloured as they approach the exterior, and an investing cuticle composed of one to four strata of large, thin, empty cells, not inaptly compared by Lindberg to the velamen or spongy cuticle investing the roots of epiphytal orchids, which also consists of large aeriferous cells.

The cells of the axis are long and cylindric, with thin colourless walls, and allow the sap to pass freely up to the growing point; those of the periphery are narrower, prismatic, and more or less lignified by internal deposit on their walls; their colour also varies according to the species, and we thus observe them in a transverse section of the stem, forming a yellow, brown, red, or blackish ring lying immediately under the cuticle; and it is to the colour of these cells appearing through the transparent cuticle that the tint of the fresh Sphagnum stem is due.

The cuticular cells are the largest, and instead of receiving any deposit they become thinner by age; they are also empty, and in some species contain fine spiral threads on their internal wall; they are also frequently perforated by foramina, by which they readily communicate with each other.

\section{The Branches.}

The branches spring from the growing cone immediately after the leaves, in the form of a little obtuse bud at the side of every fourth leaf; and when this has attained a height of three cells, the rudiments of the branch leaves also protrude themselves at the outer side.

The distinction between the central and peripheral cells of the branches is much less complete than in the stem, and the cuticular cells only form a single stratum, which is continuous with the innermost layer of the stem cuticle when this consists of more than one stratum. The cuticular cells of the branches are of two forms, as may be readily seen if we strip off the leaves, viz. large transparent parenchym cells like those of the stem cuticle, and still larger flask-shaped or retort cells, more or less 
ventricose at base, and gradually contracted upward into a more or less distinct, somewhat arched neck, which is perforated by a foramen at apex; they are very distinct in Splagnum tenellum, but in some species the neck is scarcely evident; one of these retort cells always falls at a leaf insertion, and they never contain spiral threads, even when these are present in the ordinary cells of the branch cuticle.

In most species of Sphagnum the branches which constitute each fascicle are of two forms; part of them stouter and directed outwards from their insertion, become arched at the middle and gently curve downward at the extremity, and these may be called the divergent branches; the rest are longer and more attenuated, with longer and narrower leaves, hang straight down, and are often closely appressed to the stem; these we term the pendent branches, and the number and direction of each of these in a fascicle is pretty constant in each species.

The branches always stand close to a leaf, at the end of its line of insertion on the stem, and at every fourth leaf a branch fascicle is found, their arrangement being in five straight rows, with the formula $\frac{3}{5}$, i. e. three complete turns of a spiral contain five fascicles.

Some of the uppermost divergent branches become condensed and clavate, and form the amentula of male inflorescence.

It is by means of the pendent branches and cuticle of the stem that the wonderful hydraulic property of the Sphagna is maintained, and this is readily seen if we place an uninjured stem in a glass of water and allow the top to hang over the margin, for the water rises by this channel, and soon begins to drip from the drooping end, until, like a syphon, it has drawn off all the contents. Not only do the Sphagna thus give off water to the atmosphere, but they can on the other hand also absorb moisture from it and transmit it downward; in this way a constant interchange goes on between the stagnant pools and the atmosphere, by which means no doubt the former are prevented from becoming putrid.

\section{The Leaves.}

Hofmeister admirably describes the development of the leaves of Sphagnum; they arise from the outer cell layer of the growing point, the first leaf cell appearing from the second, third, or fourth cell below the terminal one, and this dividing repeatedly by alter- 
nate, obliquely inclined septa, a leaflet is produced composed of a few large quadrate parenchym cells filled with a slimy fluid containing chlorophyl granules; but with the appearance of the fifth leaflet begins the differentiation into two kinds of cells so characteristic of the Sphagnacea.

The leaf becomes marked out into a system of square cells, each of which is surrounded by four oblong cells; in the latter chlorophyl granules rapidly increase in number and size, while the former lose all colouring matter from their contents and keep enlarging at the expense of their protoplasm; then the fibres are deposited on their internal walls, first as fragmentary rings which afterwards coalesce into complete rings or spirals; and lastly, small scattered rings appear on the internal surface, the membrane enclosed by which becoming resorbed, there result the well-known pores or foramina so generally present in the branch leaves of these plants, through which it is not uncommon to find infusoria have passed, for we may see them sporting about in the interior of the cell.

Hedwig had noticed the beautiful structure of the Sphagnum leaf, for in his Fundamenta Hist. Nat. Muscorum, i.p. 25 (1782), he mentions the large areolæ, void of chlorophyl, traversed by very fine vessels containing parenchyma, which he suggests may correspond to the ducts of flowering plants.

Moldenhawer, however, detected the true nature of the areolation, and the two kinds of cells of which it is composed, with the presence of threads and pores in the vesicular cells, and Von Mohl still further extended his researches.

The leaves of all Splragna consist of a single stratum of cells without any midrib, and these cells are of two distinct kinds alternating with each other: Ist, narrow chlorophyllose cells (ductus intercellulares of C. Muiller, interstitia of Hampe), which form a frame or network of somewhat bent hexagonal meshes, and usually six of these cells enter more or less into forming the boundary of each mesh, their colour being green, yellow, or red, according to that of their contents; these cells are really the most important part of the leaf, since they carry on the vital functions, and form the scaffold on which the hyaline cells are stretched: 2nd, large colourless vesicular cells dropped as it were into each mesh of the network, and containing in nearly all species spiral fibrils on their internal wall and perforated with foramina; for 
these cells Mr. Mitten uses the term spatia or spaces. This description applies to the leaves of the branches, but in those of the stem and perichrtium the two kinds of cells are not so distinct, as the chlorophyl is wanting and the hyaline cells are often extremely narrow, especially those at the margin, where they generally form a more or less wide border.

The stem leaves in all the European Sphagna differ considerably from the branch leaves both in form and structure; they are distant from each other, with a $\frac{2}{5}$ arrangement, or five leaves in two spiral turns, and are generally reflexed against the stem, as if pushed back by the descent of the pendent branches. Their form is oblong, ovate, or lingulate, and at their basal angles there are generally present more or less evident auricles; they are also very uniform on the same plant both in size and shape. The areolation is laxer than that of the branch leaves, and spiral fibres are rarely present in their hyaline cells; the basal cells form one or more rows of incrassate vesicular cells, more or less coloured, but the greater part of the leaf is colourless from the absence of chlorophyl in the narrow cells.

The branch leaves are small and closely imbricated, and differ considerably on the two kinds of branches, and even on different parts of the same branch; on the divergent branches they are small at base, becoming larger in the middle of the branch, and narrower and more distant towards the point ; the three or four at the extreme base of the branch are very small and have a peculiar shape, being somewhat obliquely triangular in outline, and partly resemble the stem leaf in areolation; in fact, they convey the idea of one half of a stem leaf which has been split down the middle, and possibly may originate by being torn apart by the separation of the branches forming the fascicle, at their first stage of development.

Russow attaches importance to these leaves, and.names them intermediate leaves, but they are not always alike in the same species, nor do they offer much variety in different species, and they have always a broad border of narrow cells; the leaves of the pendent branches are all longer and narrower, as are also their component cells.

The relation of the two forms of cells to each other, in the anatomy of the ramuline leaves, is a point of great importance, since it originates in the fundamental formation of the leaf, and it therefore takes part in the diagnosis of species; to observe this 
properly some care is requisite, for the transverse sections must be very thin and examined in water by a good light. We thus find four modifications of the position of the chlorophyllose cells :-

Ist. They may lie midway between the anterior and posterior surfaces of the leaf, being entirely enclosed by the hyaline cells, and the section shows that they are lenticularly compressed.

2nd. They may emerge between the hyaline on the anterior or ventral surface of the leaf, their section being triangular, so that they resemble a cushion or wedge pushed in between each pair of hyaline cells.

3rd. They may occupy the same position on the posterior or dorsal surface.

4th. They may emerge both in front and back-a condition observed only in a few species, and in this case their section is circular or oval.

The hyaline cells are more or less united by their adjacent walls, and where they are applied to the chlorophyllose cells the walls of the two become grown together; in some species this combined wall, as seen from the interior of a hyaline cell, is covered over with minute deposits which take the form of papilla, bars, or crests, and by some authors have been erroneously described as remains of spiral fibres; these are beautifully seen in our S. Austini and papillosum, and in the foreign S. Portoricense and Herminieri.

The hyaline cells nearly always contain threads attached to their internal walls, and these threads may form complete spirals composed of one or several fibres, or they may be broken up into rings, and fragments sometimes run across diagonally so as to unite two spirals; they are firmly and intimately united to the inner wall of the cells, and often, e.g. in S. subsecundum, tightly lace up and contract the cells at each turn of the thread, probably by contraction soon after its deposition.

The fibrils are not always present in all the leaves; thus in $S$. fimbriatum they are wanting in both the stem and perichrtial leaves, and some have them in one half of a stem leaf, as $S$. cuspidatum, where they are found in the upper part, but in S. macrophyllum no threads are found in any part of the plant.

By some authors the presence or absence of threads in the cells of the stem leaves has been looked upon as of specific value, but a study of the varieties of the common species $S$. acutifolium and 
cymbifolium will soon convince any one that it is a character on which no reliance can be placed. As the purpose of the fibres seems to be to preserve the shape of the vesicular cells and support their delicate walls, we should naturally expect to see them most abundant in the compact or denser forms, and such we find to be the case, for in the short, close-branched forms of S. acutifolium the cells of the stem leaves are fibrillose throughout, but in the tall, slender forms they are altogether absent.

The pores or foramina stand near the adjacent cell walls, and are usually found on the posterior surface, but in S. tenellum they are on the anterior, and in a few species both front and back are perforated, as in $S$. rigidum. Their size varies in different species; thus in S. acutifolium and cymbifolium they are very large, in S. subsecundum and cuspidatum very small. Besides these, Russow calls attention to larger apertures which become visible after treatment with iodine and sulphuric acid, and indicate more extensive resorption of the cell membrane; thus in the lower part of a branch leaf of $S$. fimbriatum so treated, these large openings reach across the whole width of the cell. The word lumen is applied by continental authors to denote the clear space in the interior of a cell through which light is transmitted, or the space bounded by the internal lining of the cells.

In S. finbriatum, strictum, Lindbergii, and others which have stem leaves fringed at the apex, this appearance is due to resorption of the membrane of the marginal hyaline cells, and consequent projection of the intermediate parenchym cells.

The bracts or leaves of the perichrtium which surround the elongated receptacle of the fruit, are much larger than the other leaves of the plant, and in areolation are intermediate between those of the stem and branches, though coming nearest to the former; their chlorophyllose cells usually present deficiencies in the thickening layers of their walls, and these standing opposite each other resemble imperforate pits, not unlike the dotted pleurenchyma of the wood of conifers, and a similar condition is observable in the walls of young axile cells of the Sphagnum stem (Hofmeister's - Higher Cryptogamia,' pl. xvii. fig. 9b).

The bracts of the male inflorescence correspond with the branch leaves in structure, though they are usually broader and shorter; but they frequently are adorned in addition with rich colours, which vary according to the species. 


\section{CHAPTER IV.}

THE REPRODUCTIVE 'SYSTEM.

THE organs necessary for impregnation and subsequent fruit formation are of two kinds, antheridia-male, and archegonia or pistillidia-female; they differ, however, from those of the frondose mosses, and are arranged in a different manner. These two organs have never been found together in one inflorescence (synoicous), as is so frequently the case in mosses, but they occur separately on lateral shoots either of the capitulum or of some of the fascicles below it, and they may both be produced on one stem, or the different organs are on separate plants; thus all Sphagna are either monoicous or dioicous.

\section{The Antheridia.}

These are arranged in slender catkins or amentula, somewhat resembling those found in the Fungermanniacea, and occupy the apical part of a certain number of the divergent branches, or by a continued growth of the branch beyond the male inflorescence, the latter not unfrequently appears confined to the centre of the branch.

Each antheridium is attached to the branch singly at the end of the insertion of its covering bract, to which it stands in the same relation as the branch fascicles do to the stem leaves.

The antheridium originates in a cell derived from the outer indurated. stratum of the branch; this cell divides by a transverse septum into two, the lower one becoming the slender pedicel, the upper the globose body containing the antherozoids; the wall of the antheridium consists of a single stratum of large, angular, clear cells. The pedicel is long and of extreme tenuity, the sac globose or ovate, and pale green, appearing as if encircled by a hyaline ring; this, however, is not the case, although Hedwig and some recent bryologists have regarded it as such, and compared it to the jointed annulus of the Ferns, but the appearance is due to the large cells being so transparent that they are only seen distinctly when 
we view them in profile, and also to the central aggregation of the contents of the organ. The antheridium bursts at the apex, the margins of the aperture rolling back, and a cloud of lenticular vesicles escapes, each of which contains a spirally coiled antherozoid. The antherozoids are soon set free, and glide about with great activity; their form is that of a fine thread of $2 \frac{1}{2}$ coils, clavately thickened at one end, and at the opposite attenuated extremity provided with two long, extremely fine vibratile lashes.

Surrounding the antheridia are exceedingly fine web-like paraphyses, which differ widely from those of mosses in being branched and twisted; they arise from the cuticular layer of the branch, and no doubt convey moisture to sustain the vitality of the antheridium, but they disappear as soon as fertilization of the archegonium is completed.

The bracts or covering leaves of the male inflorescence resemble the ordinary branch leaves in structure, but are shorter and more closely imbricated, and also often richly coloured, being purple in $S$. acutifolium, fulvous in $S$. cymbifolizm, ochraceous in $S$. intermedizm, \&c.

\section{The Archegoniun.}

The female inflorescence appears on a short lateral branch at the side of the capitulum, and at first takes the form of a long, attenuated, deep green bud of sheathing perigynial leaves, the innermost of which are the longest. Within these, and surrounded by the rudimentary perichætial bracts, are one to four archegonia, resembling those of true mosses, but having fine branched paraphyses like those of the male inflorescence. They have shorter pedicels, and consist of an oblong ventral part which elongates upward into a cylindric neck or stylidium, formed of six rows of cells.

The first formation of the archegonia and progress of their development are fully described in the respective treatises of Hofmeister and Schimper. When arrived at maturity the apex of the archegone swells up and bursts, and the margins roll back, leaving a trumpet-shaped orifice; this aperture extends downward as a fine tube to the cavity of the archegonium, and forms the channel down which the antherozoids pass to fertilize the central cell.

M. Roze observed the mode of impregnation of the archegone by placing sone mature but still closed ones in water on a slicle, 
when he found that dehiscence took place after about an hour's immersion; he then placed in water also some antheridia, which on rupturing charged the fluid with abundance of antherozoids, and some of this he added to the other preparation.

He found that the antherozoids did not seem to have any tendency to direct themselves towards the entrance of the canal, but reached it fortuitously, and then appeared to introduce themselves with difficulty; the ciliated extremity which consists of an amylaceous granule always goes first, and it is sometimes arrested by the plasma in the canal, and then struggles to clear itself; this accomplished, it moves on more briskly until it reaches the germinative globule suspended in the fluid in the archegonial cavity; on this it fixes itself, all movement ceases, and a direct fusion of the two appears to take place.

Only one archegonium develops into fruit, and after impregnation the apex and canal become coloured red or yellow; the pedicel then enlarges, for the fertilized germinal cell passes down into it to become the fruit, and bears the now hollow ventral portion with the shrivelled stylidium on its apex. This germinal cell is pyriform and contains a large nucleus, and as soon as impregnation takes place, active cell multiplication is set up, and the single cell becomes an oblong body filled with slimy fluid and minute granules, and the pedicel is no longer defined from the ventral part; through the soft pedicel the embryo fruit forces its way down, and so into the interior of the fruit receptacle, which has become elongated and obtusely conical.

Next, the embedded pedicel of the embryo expands in width by cell multiplication, and becomes a hemispherical protuberance elevated above the dome-shaped receptacle. The cells lying at the base of the pedicel alone continue to divide transversely, and the pedicel itself becomes nearly spherical, and not being able to penetrate farther downward, it with the cuticular and peripheral layers covering it becomes elevated upward. During the rapid extension of the lower part of the fruit, the inner cellular texture of the lower portion of the archegone has disappeared, and the rudimentary capsule has developed to a short cylinder, its outer coat consisting of a single layer of very thin cells, which corresponds to the calyptra, gradually stretches, becomes still thinner by the swelling of the young capsule, until it bursts or tears into shreds; rapid cell multiplication goes on in the fruit, and a spherical capsule 
results, whose outer coat consists of two cell layers, beneath which lies another series of three strata, the cential of these consisting of rather larger cells become parent cells of spores, while the stratum on each side of it represents the inner and outer wall of the future spore sac. The mother cells of the spores are globular, and their contents divide transversely by cross walls into four pyramidal spores; or each of these again divides into four to form the rarer microspores.

\section{The PERFECT Fruit.}

The capsule is normally placed in the capitulum, but it frequently happens that a rapid extension of the internodes takes place, and thus the fruits are left behind at various heights on the stem; this usually happens by some change in the local conditions, as, for instance, a sudden submergence of the plants by a wet season.

As the fruit receptacle elongates to a pseudopodium it draws apart also the perichætial bracts, which are larger than the leaves and surround it at the base, and to a greater or less extent above it, according to its rapidity or slowness of growth.

The Sphagna were by all the early bryologists described as being without a vaginula, and Bridel formed them into a separate section termed Evaginulati, but Professor Schimper indicates as the vaginula the turbinate swelling below the capsule, which is the dilated apex of the receptacle. In the Acta Soc. Scient. Fennicre, x. p. 264, Professor Lindberg points out that the pseudopodium which carries the fruit differs from a branch in having the same number of cuticular cell strata as the stem, though not so well developed, and that this organ is truly nothing else but an elongated vaginula. Up to the maturity of the capsule it remains enclosed in the perichrtium, the receptacle then clongates and elevates the capsule, which is inserted by its bulbiform pedicel in the expanded apex.

The calyptra is the continuation upward of the outer cell layer of the vaginula and fruit receptacle, and is very thin and colourless ; it encloses the young capsule like a sac closely stretched over it, and does not separate in any determinate way as in mosses, but is ruptured irregularly by the enlargement of the capsule and splits into shreds, a portion being generally left attached to the base of the capsule.

The capsule is very uniform in all the species, being almost 
spherical, but when the lid is cast off it becomes urn-shaped or cylindric, and the mouth never exhibits any trace of peristome; the walls are brittle and bear numerous stomata on the surface, and when ripe are of a deep chestnut brown colour.

The operculum or lid is flattened or in form of an inverted saucer, and is cast off by contraction of the capsule with a crackling noise or slight explosion, and at the same time the spores are driven forth by compression of the capsule walls. Not unfrequently the lid remains attached by one margin, which acts as a hinge, and the capsule is closed again when moistened. If the capsule remains submerged or always wet, the lid does not open, but the capsule falls away from the vaginula and a hole is left at the base, the columella decays and the spores can escape in this way, or it happens that they germinate while still enclosed in the capsule and burst it by expansion, or the lid may be forced off and the capsular wall only left with a hole at each pole, and such barrelshaped shells we frequently meet with in our examination of Sphagnum tufts.

The spore sac differs in shape from that of the true mosses, for it is in form of a hollow hemisphere, occupying the upper part of the capsule and resting on the top of the columella to which its inner wall is united, while the outer wall coheres to the inner celllayer of the capsule wall. When mature, the columella breaks away from the vaulted under side of the spore sac and shrivels back to the base of the capsule, leaving an empty space, which is probably concerned in the bursting of the capsule.

The two kinds of spores are found in the same capsule or in different ones. The large spores vary between $2 \frac{1}{2}$ and $4 \frac{1}{2}$ hundredths of a millimetre in diameter, and in colour present various shades of yellow, ochraceous, or ferruginous brown; the exospore or external coat is covered with scattered papillæ. 


\section{CHAPTER V.}

ARRANGEMENT OF THE SPECIES.

IT is always convenient to distribute the species of a genus into groups or sections, especially when they happen to be numerous and difficult of diagnosis; this has been attempted with respect to the Sphagna in various ways by different authors, and it may be of advantage to present an outline of each of these.

BRIDEL, in his Bryologia Universa (1826) arranged his sixteen species as follows, classing them as Musci Evaginulati Cladocarpi :-

I. Ramuli distinctly fasciculate.

$a$. Leaves broader, rather obtuse.

S. cymbifolium tenellum, squarrosum, contortum, subsecundum, immersum, oblongum, macrophyllum, denticulatum.

b. Leaves narrower, rather acute.

S. capillifolium, recurvum, cuspidatum.

2. Ramuli indistinctly fasciculate.

S. compactum, evicetorum, condensatum, subulatum.

C. MülLer, in his valuable Synopsis Muscorum (1848), made a great advance on the writings of previous authors by introducing the cell structure of the leaves into the specific character of these mosses. He points out the differences in the leaves of the stem, branches, and peduncle, and the presence or absence of spiral fibres in them.

1. Leaves without annular fibres.

S. sericeum, macrophyllum.

2. Leaves with annular fibres.

a. Leaves rounded at apex.

S. cymbifolium, \&c.

b. Leaves truncate.

* Peduncular leaves without spiral fibres.

S. mollzuscum, squarrosum, cuspidatum, acutifolizm, Sc. * Peduncular leaves with spiral fibres.

S. laxifolizm, compactum, molluscoides, subscunadum, Sc. All the species are said erroneously to be dioicous. 
Wilson, in Bryologia Brit. (I855), arranged them somewhat as Bridel.

I. Leaves obtuse, rounded, or elliptic.

S. cymbifolium, compactum, molluscum, rubellum.

2. Leaves acuminate, ovate or ovato-lanceolate.

a. Leaves erecto-patent.

S. acutifolium, fimbriatum, cuspidatum, contortum.

aa. Leaves squarrose.

S. squarrosum.

Sullivant, in his Mosses of the United States (1856), forms four groups, characterized by the relative position of the cells in the branch leaves, as seen in transverse section-a valuable distinction, no doubt, but far too minute and difficult of observation to be of practical utility.

I. Chlorophyllose cells entirely enclosed by the hyaline, and not reaching either surface of leaf.

S. cymbifolium, compactum, contortum, Lescurii, tenerum, humile, cyclophyllum, sedoides.

2. Chlorophyllose cells oval, reaching to both surfaces of leaf.

S. squarrosum, macrophyllum.

3. Chlorophyllose cells triangular, placed between the hyaline at the concave or inner surface of leaf.

S. acutifolizm, fimbriatum, tabulare, molle.

4. Chlorophyllose cells triangular, placed between the hyaline at the convex or outer surface of leaf.

S. cuspidatum, Torreyanum.

Schimper, in his monograph, divides the species into two groups-monoicous and dioicous-a plan of very little practical help, since it is of no use with plants in a barren state. The same arrangement is followed in the Synopsis Musc. Europ. ed. I (1860).

C. Hartman, in the eighth edition of the Scandinavian Flora (186I), uses the stem leaves for this purpose, thus:-

I. Apex of cauline leaf broad, strongly and distinctly fimbriate in its whole margin.

S. cymbifolium, Angströmii, Lindbergii, fimbriatum.

2. Apex indistinctly fimbriate or lacerate.

S. rigidum, squarrosum, subsecundum, teres.

3. Apex with a few distinct teeth, not fimbriate or lacerate.

S. acutifolium, Mülleri. 
4. Apex entire or indistinctly denticulate.

S. molluscum, rubellum, cuspidatum.

This, it will be seen, is readily applicable, but it has the disadvantage of bringing together species not otherwise the least allied.

LindBerg, in Ofvers. K. Vet. Ak. Förhandl. for I 862, after separating $S$. macrophyllum as a genus $Y$ socladus, arranges the rest as follows :-

1. Homophylla. Plants glossy, shining; hyaline cells quite free from spiral fibres.

S. sericenm, Holleanum.

2. Heterophylla. Plants opake; hyaline cells furnished with spiral fibres.

A. S. cuspidata.

S. cuspidatum, Lindbergii, recurvum, finbriatum, acutifolium, teres, squarrosum.

B. S. rigida.

S. rigidum, Müllevi, Angströmii.

C. S. subsecunda.

S. subsecundum, rubellum, tenellum.

D. S. cymbifolia.

S. cymbifolizm.

These groups are natural, have several characters in common, and are also adopted by Russow and Milde, except that they alter rigida to trnncata, a more appropriate term, since it is applicable to all three species.

I have also followed this arrangement, but at Professor Lindberg's suggestion have reversed the order, so as to commence with what we must consider the most highly developed species of the genus.

Schliephacke, in the paper already referred to, proceeds on the same plan, but increases the number of groups to seven, as follows :-

I. acutifolia.

S. rubellum, acutifolium, fumbriatum, Wulfianum.

2. cuspidata.

S. cuspidatum, laxifolium, Lindbergii.

3. squarrosa.

S. teres, squarrosum.

4. rigida.

S. rigidum, Mülleri, Angströmii. 
5. mollusca.

S. molluscum.

6. subsecunda.

S. laricinum, subsecundum.

7. cymbifolia.

S. cymbifolizm.

Some of these, however, appear to be ill-defined and unnecessary.

Scrimper, in the new edition of his 'Synopsis,' adopts this arrangement, but alters rigida to mollia, and unites mollusca to subsecunda. Klinggräff also in his paper has the same six groups. 


\section{CLAVIS TO THE SPECIES HERE DESCRIBED. SPHAGNUM.}

Sect. I.--Eusphagnum, Lindb.

Branches dimorphous, part divergent, part pendent; their leaves with spiral fibres. Capsule oblong, small-mouthed.

A. Cymbifolia. Cuticular cells fibrillose. Branch leaves cymbiform-concave, the apex cucullate, squamoso-scabrous at back.

Branch leaves with the lateral wall of the combined hyaline and chlorophyllose cells covered with papillæ.

Branch leaves minutely fringed all round the margin.

Branch leaves not fringed.

Portoricense.

Chlorophyllose cells trigonous, emerging on the concave surface of leaf. Papillæ transverse, in a single series.

Austini.

Chlorophyllose cells lenticular, entirely enclosed by the hyaline. Papillæ wart-like, numerous, scattered.

papillosum.

Branch leaves with the lateral wall of the combined hyaline and chlorophyllose cells smooth.

cymbifolinm.

B. Subsecunda. Branch leaves more or less secund, ovate, with rounded toothed points; the margin involute in the upper half.

Retort cells of branches large, curved outward at apex. Hyaline cells of branch leaves large.

tenellum.

Retort cells of branches small, cylindric. Hyaline cells of branch leaves small.

Cuticular cells of stem in a single layer. subsecundum.

Cuticular cells of stem in $2-3$ layers.

laricinum.

C. Truncata. Branch leaves oblong, the point truncate, strongly toothed, margin involute for all its length.

Stem leaves very small, tongue-shaped; branch leaves ovate-oblong, toothed at apex.

rigidum.

Stem leaves truncate, many-toothed; branch leaves broadly ovate, acuminate, with 6-ro teeth.

Angströmii.

Stem leaves very large, ovato-lanceolate, 3-toothed; branch leaves ovate-oblong, 3-5 toothed. molle. 
D. Cuspidata. Branch leaves ovato-lanceolate or narrowly lanceolate, with the points elongated, truncate, and toothed; margin strongly involute at point.

Branches 7-I 2 in a fascicle.

Wulfii. Branches $3^{-6}$ in a fascicle.

Stem leaves narrower at base than above.

Stem leaves rounded at apex, fringed all round the upper half.

fimbriatum.

Stem leaves truncate, only fringed along the transverse margin.

Lindbergii.

Stem leaves not narrower at base.

Stem leaves not bordered; branch leaves squarrose.

squarrosum.

Stem leaves broadly bordered with narrow cells; branch leaves erecto-patent.

Branch leaves with very large pores.

Stem leaves tongue-shaped, more or less pointed.

acutifolium.

Stem leaves as wide above as at base, truncate, fringed at apex. strictum.

Branch leaves with very small pores.

Stem leaves triangular, cells of border rathershort.

Pendent branches concealing stem. Cuticular cells thin and indistinct. intermedium.

Stem leaves triangular, cells of border very narrow and elongated. Pendent branches not concealing stem. Cuticular cells distinct. cuspidatum.

\section{Sect. II.-HemitiecA, Lindb.}

Branches homomorphous, solitary or in pairs; their leaves with spiral fibres. Stem leaves and branch leaves alike, obtuse. Capsule wide-mouthed, hemispherical.

Pylaiei.

\section{Sect. III.-Isocladus, Lindb.}

Branches homomorphous, fascicled, all arcuato-divergent; their leaves lanceolate-subulate, without spiral fibres, but with a central longitudinal row of pores. Capsule as in Sect. I. macrophyllum. 


\section{MONOGRAPH OF THE SPECIES FOUND IN EUROPE AND NORTH AMERICA.}

\section{SPHAGNUM, Dillen.}

Stems dichotomous, fastigiate, erect, renewed by an annual innovation at apex; ramuli fascicled at base, flagelliform, partly patulous, partly adpresso-reflexed; the younger clavate, erect, clustered in a dense capitulum at summit of stem. Cauline leaves 5-ranked, erecto-incumbent or reflexed, soft; ramuline leaves imbricated, nerveless, pale and fragile when dry; the areolation composed of large vesicular, sigmoid, hyaline cells, containing spiral fibres and perforated by pores, and separated by narrow duct-like opake cells placed between their adjacent walls. Inflorescence monoicous or dioicous; the male strobiliform on lateral ramuli, antheridia very numerous, solitary at the side of each involucral bract, pedicellate, subglobose; female forming long gemmules with $\mathrm{I}-5$ archegonia, and branched, thread-like paraphyses. Fruit solitary, concealed in the perichætium, and at maturity elevated on an elongated pseudopodium. Capsule globose, sessile on the top of the vaginula, brown; operculum minute, hemispherical, without annulus or peristome; columella elevated, hemispheric, covered by the excavato-hemispheric sporangium; pericarpic membrane very thin, whitish, torn irregularly, adhering partly to the capsule, partly to the top of the vaginula.

Plants dwelling in marshes and peat bogs, aggregated in dense tufts or cushions, which consist all of one species or of an admixture of two or more; absorbing water with great avidity and retaining it like a sponge.

\section{Sect. I.-Euspitagnum, Lindb.}

Plants pale green, whitish, or ochraceous, occasionally more or less tinged with purple. Branches of two forms, in distinct fascicles of $3^{-1}$ 2, part divergent or decurved, part attenuated, slender, and pendulous. Branch leaves imbricated, ovate or ovato-lanceolate, the cells rhomboidal, curved, containing fibres, and with marginal pores. Perichætial bracts much larger, broad, and convolute. Capsule exserted, globose, with a shallow, convex lid. 


\section{Group A.-CYMBIFOLIA.}

Plants robust. Branches turgid, those of the coma rounded and obtuse at apex, the cuticular cells fibrillose ; branch leaves inbricated, very broad, cymbiform-concave, ovate or roundish, with an involute rounded cucullate apex.

\section{Sphagnum Portoricense, Hampe.}

PL. II.

Dioicous? tall, robust, fuscescent; the stem with 2-3 layers of cuticular cells. Stem leaves subquadrate-ovate, fimbriate all round the margin. Divergent branches subclavate-fusiform, with closely imbricated leaves, the cuticular cells spirally fibrillose, their transverse walls geniculate downwards. Branch leaves orbiculate-ovate, cucullate, squamose at back, minutely fimbriate all round the margin ; chlorophyllose cells triangular in section, placed between the hyaline on inner surface of leaf and crested with papillex where united to them.

Synon.-Sph. Portoricense, Hampe, Linnæa, 1852, p. 359. Sullivant, Ic. Musc. p. 3, tab. 2 (1864). Austin, Musc. Appalach. No. I (1870).

Sph. Sullivantianum, Austin, in Amer. Journ. Sci. r863, p. 252.

Dioicous? in large soft tufts, pale fuscous below, pale glaucous green above. Stems 8-I 4 in. high, stout, simple or bipartite, firm, pale brown; cuticular cells in 2-3 layers, containing spiral fibres, but few pores. Stem leaves erect or deflexed, auricled, subquadrate-ovate, fringed round the entire margin; upper cells rhomboidal, lower elongated, all without fibres or pores.

Ramuli $4-5$ in a fascicle, $2-3$ divergent, arcuato-patent, subclavate-fusiform, attenuated at base, the leaves julaceously imbricated; pendent branches more slender, lax-leaved. Cuticular cells spirally fibrillose, with few pores, the transverse walls geniculate downward into the subjacent cells, and usually having a pore at the apex of the bend.

Leaves of the divergent branches small below, and widely cordate or semicircular, becoming larger above, narrowed at base, the median orbiculate-ovate, squamoso-scabrous at back of the strongly cucullate apex, very narrowly bordered; all minutely fimbriate throughout, the fibrils of the fringe formed by the commissural walls of destroyed hyaline cells; lower hyaline cells elongato-rhomboidal, upper rhombic, with parallel linear papilla 
internally on the wall where united to the chlorophyllose cells, all fibrillose, with several large pores at the margin; chlorophyllose cells triangular in section, interposed between the hyaline on the concave surface of the leaf. Fruit unknown.

HAB.-Swamps in mountain districts. N. America: Manchester ponds, Ocean County, New Jersey (Austin). First found by Schwanecke in Porto Rico.

This fine and rare species worthily heads the genus, and with the two following and Sph. Herminieri, ScHimp., from Guadaloupe, constitute a small natural group having the internal lateral wall of the hyaline cells variously covered with crests or papillæ. The present may be at once distinguished by the beautifully fringed margin of the branch leaves, and by the curious downward prolongation of the transverse wall of the cuticular cells of the branches, which may be readily observed in the series of cells at each lateral margin.

\section{Sphagnum Austini, Sullivant.}

PL. III.

Dioicous, green above, ochraceous or brown below, the stem with four layers of cuticular cells. Stem leaves lingulate, obtuse. Divergent branches two, attenuated, the cuticular cells spirally fibrillose. Branch leaves closely imbricated, ovate-oblong, somewhat cucullate, squamose at back; chlorophyllose cells obtusely trigonous, placed between the hyaline on inner surface of leaf, and transversely crested with papillæ where united to them.

Synon.-Sph. Austini, SUll. in Aust. Musci Appal. p. 3, n. 2 (1870), et Ic. Musc. Suppl. t. I, p. 9 (1875). LindB. in Act. Soc. Sc. Fenn. x. p. 280, in addend. ( 1872$)$, in Bot. Not. 1873, p. 45, et in Not. ur Sällsk. pro Fn. et Fl. Fenn. Förh. xiii. p. 39I (1874). Braitirw. in Monthl. Micr. Journ. May I873, p. 215, t. I7, et Sphag. Brit. Exsic. n. I (I 877). Cooke, Grevillea, ii. p. 61 (1873). Schimp. Synops. ed. 2, p. 849 (r876).

Dioicous, in elevated densely-cushioned tufts ; soft, robust, pale green above, fusco-ochraceous below. Stems $4-8$ in. high, frequently dichotomous, dark brown; cells of the peripheral layers strongly incrassate, red brown; cuticular cells in four strata, the outer quadrato-hexagonal, without fibres, the inner with very fine fibres and large pores. Stem leaves erect, lingulate, obtuse, minutely fringed at apex; the hyaline cells empty above, fibrose and porose below. Branches closely placed, three in a fascicle, two divergent, arcuate, attenuated towards point, one pendent, 
short, slender, appressed to stem; cuticular cells quadrato-hexagonal, fibrose, and porose.

Leaves of divergent branches closely imbricated, ovate-oblong, concave; the margin inflexed and cucullate at apex, which is more deeply coloured, less obtusely rounded, strongly squamoso-scabrous at back. Cells large, flexuose, the hyaline filled with fibres and having several large foramina; the chlorophyllose obtusely trigonous, projecting between the hyaline on the concave surface of leaf; the internal wall of the hyaline cells, where united to the chlorophyllose, densely crested with prominent transverse, linear, parallel papillæ.

Perichrtia few, placed in the coma; bracts large, oblong, convolute, minutely fimbriate at the rounded apex; cells of the lower third empty, narrow, parenchymatous, above normal, more or less fibrose, with large pores, the internal walls transversely striatopapillose. Capsule moderately exserted, dark brown. Spores ferruginous. Male inflorescence amentiform, on the subinflated apex of the branches of the coma.

HAB.-Wet mountain heaths and peat-bogs, especially near the sea-coast.

EUROPE.-Srveden: Hunneberg Mountain, Westrogothia (Lindberg, 1859); Östanfalla, Nerike (Zetterstedt, 1860), and at Villingsberg with fruit (C. Hartman, 1875); below Skäralid, Riseberga, Skåne (Lindberg, 1875). England: Lyth Moss, Westmoreland (Barnes, 1876 ).

N. America.-Near Farrago and Manchester, Ocean County, New Jersey, with fruit (Austin, 1862).

In Sph. Austini the papillæ or crest-like elevations on the internal lateral walls of the hyaline cells are transversely linear, and when well developed give a pectinate appearance to the chlorophyllose cells; but in the Westmoreland plant these are less distinct than usual, and it might thus be confounded with Sph.papillosum, from which, however, it may be known by a thin transverse section of a branch leaf, in which it will be seen that the chlorophyllose cells emerge at the ventral surface of the leaf, instead of being enclosed on both sides by the hyaline. Though resembling Sph. papillosum much in habit and colour, it is altogether of softer texture.

\section{Var. $\beta$. imbricatum (HoRNSCH.), LINDB.}

Colour darker brown, growing in very dense tufts. Plants very tumid from the crowded fascicles of branches, which are short, tapering at points, with closely imbricated leaves. 
Synon.-Sph. imbricatum, Hornsch. Mss. Russ. Torfm. p. 2 I (1865).

Sph. cymbifolium var. $\beta$. condensatum, C. MüLl. Synops. i. p. 92, p. p. (1848).

Sph. Austini var. $\beta$. imbricatum, LindB. in Act. Soc. Sc. Fenn. x. p. 280 , in addend. (1872), Bot. Not. I873, p. 45, et Not. ur Sällsk. pro Fn. et Fl. Fenn. Förh. xiii. p. 392 (1874). Braithw. Sphag. Brit. Exsic. n. 2 (1877).

HAB.-Island of Lewis, Western Hebrides (Dr. Moore, I868); Witherslack Moss, Westmoreland (Barnes, 1875). Forming very dense tumid hassocks.

This variety was first found in Kamtschatka by Redowski, and fertile specimens quite resembling the Hebridean plant were collected in Chiloe by Captain King.

It is worthy of note that the climate of Lewis appears closely to resemble that of some of the Antarctic islands, and I observed in the grounds of the castle that the beautiful Escallonia macrantha formed immense bushes, which bloomed profusely. The bare moorlands which compose almost the entire island, are dotted over with innumerable great cushions of Rhacomitrium lanuginosum more hoary than usual, and with these between Stornoway and Garynahine occur the great tussocks of our Sphagnum, so large, indeed, that they attracted the attention of Dr. Moore while driving along the road, and not more than three of these have yet been met with. The stems of the moss are much intermixed with very fine, branched, brown radicles, and in the plant from Witherslack is a large admixture of Odontoschisma sphagni, the filiform radicles of which are interwoven with the stems of the Sphagnum.

\section{Sphagnum papillosum, LindBerG.}

PL. IV.

Dioicous; more or less ochraceous, the stem with four layers of cuticular cells. Stem leaves spathulate, rounded and minutely fringed at apex. Branch leaves closely imbricated, cymbiformconcave, cucullate at apex, rounded ovate, broad, their chlorophyllose cells central, enclosed by the hyaline, and densely and minutely papillose where united to them. Perichætial bracts oblong, plicate, their cells of two forms; in the lower half the central part consists of narrow, empty, pleurenchymatous cells, the margins and upper half of porose and fibrose cells.

Synon.-Sph. papillosum, Lindb. in Act. Soc. Sc. Fenn. x. p. 280 , in addend. ( 1872 ), in Bot. Not. 1873 , p. 45, et in Not. Sällsk. pro Fn. et Fl. Fenn. Förh. 1874, p. 392. Bralthw. in Monthl. Micr. Journ. May 1873, p. 214 , pl. 16, et Sphag. Brit. Exsic. n. 3, 4, et $8 b$ (I 877 ).

Sph. obtusifolium, Auct. p. p. 
Sph. cymbifolium, Aucr. p. p. et var. $\gamma$. Scнiмp. Synops. ed. 2, p. 848 (I876).

Sph. cymbifolium var. a. turgidum, MarTius, Fl. Crypt. Erlang. p. II 7 (I817). NeEs, in Bryol. Germ. i. p. 8, tab. I, fig. I. BRID. Bry. Univ. i. p. 4. (Sententiâ Lindbergii huc pertinet.)

Sph. immersum, CASSEBEER, Wetterauische Laubmoose, n. 8 (1 $83_{2}$ ).

Sph. palustre, Brotherus, Musci Fenniæ Exsic. n. 43 (1871).

Dioicous; in lax distinct tufts, or intermixed with other species; pale ochraceous or pale brownish green, never tinged with purple.

Stems 4-ro in. high, simple or bipartite, stout, fragile, reddish brown; cells of the peripheral layers strongly incrassate, dark brown; cuticular cells in four strata, those of the innermost and outermost layer being the smallest, the external without fibres, but with several pores. Stem leaves reflexed and appressed to stem, cucullate, spathulate-linguiform, rounded, obtuse and slightly fimbriate at apex, somewhat auricled at base, margin plane, serrulate; lowest basal cells brownish, globose, incrassate, above rhombic, faintly fibrose, and with a single foramen at back.

Ramuli $3-5$ in a fascicle, two divergent, short, acute, the rest dependent, attenuated, appressed to stem; cuticular cells densely fibrose, rectangular, with a large foramen at upper end.

Leaves of divergent branches dense, rigid, patent, slightly auricled, coloured brown at apex; lowest small, obliquely ovatotriangular, with a broad hyaline border, median very broadly ovate, cymbiform-concave, rounded obtuse at apex, deeply cucullate, bordered with a single row of very narrow cells, margin densely serrulate above.

Cells at base as in the stem leaves; all the hyaline internally where their walls are united with those of the chlorophyllose cells, densely and minutely papillose; median prosenchymatous with dense spiral and annular fibres, and several large marginal foramina on the under surface; upper rhombic, with foramina also on the upper surface, and in the apical the foramen at back is so large that nearly all the membrane disappears, and thus the tuberculate appearance is produced; in section the chlorophyllose cells are narrowly elliptical, central, and enclosed by the hyaline.

Perichætia several, placed in the coma ; bracts about eighteen, large, accrescent, erect, oblong, rounded, truncate and cucullate at apex, channelled-plicate; cells in the middle of lower half of two forms, very large and long, pleurenchymatous without papilla or 
fibres, and chlorophyllose; in the upper half papillose and fibrose with foramina on both sides, as are also the marginal nearly to base.

Capsule subglobose, brown; spores ferruginous.

Male plants in distinct tufts, resembling the female; amentula apical on divergent branches, ochraceous or brownish ; bracts round, cochleari-concave, with the structure like that of the branch leaves; the barren branches of the coma few and short, as compared with those of Sph. cymbifolium.

HAB.-The smaller peat-bogs in subalpine districts, and especially in drains and cuttings filled with water. Fr. July.

EUROPE.-Finland: First found at Helsingfors by Lindberg, and since in various other places and in the islands of Hogland and Aland. Sweden, Norway: Dovrefjeld, Christiania, \&c. (Blytt). Germany, Westphalia, \&c. England: Darnholm, Goathland, Yorkshire (Braithwaite); Penzance (Curnow); Barrowfield, intermixed with Sph. cymbifolium, and Witherslack Moss, Westmoreland, in fine fruit (Barnes). Scotland: Ben Lawers, Perthshire; moors near Loch Achilty, Ross, and near Garynahine, Isl. Lewis, Hebrides (Braithwaite); Dalfroo and Dalbrake bogs, Strachan, Kincardine, and Reawick, Shetland (Sim). Ireland: Killarney, Brandon Mountains, \&c. (Moore, Lindberg).

N. America.-Has been found mixed with Sph. cymbifolium.

This elegant species has, no doubt, been always mistaken for Sph. cymbifolizm, but in the growing state it has quite a different aspect, being a coarser and more rigid plant, and when removed from the water the branches retain their position and do not fall down and collapse against the stem, and they are much shorter and less attenuated at points.

The plants are generally more or less tinged with ochraceous, and this tint is most conspicuous on the apices of the branch leaves, showing much more affinity to Sph. Austini than to Sph. cymbifolium. The papillæe which cover the internal walls of the combined hyaline and chlorophyllose cells are somewhat variable in distinctness, but with a good illumination are seen to differ in size and to be in form of a low obtusely-pointed cone. Professor Schimper strangely regards these characters as of small importance, and not sufficient to constitute a species.

\section{Var. $\beta$. confertum, Lindi.}

Plants much smaller, dense, frequently dichotomous. Branch leaves round, deeply cochleari-concave and obtuse. Bracts of perichætium shorter. 
Synon.-Lindb. Notis. ur Sällsk. pro Fn. et Fl. Fenn. Förh. xiii. p. 400 (1874). Brarthw. Monthl. Micr. Journ. May 1873, p. 215, et Sphag. Brit. Exsic. n. 5 (1877).

HAB.-In marshes on drier subalpine heaths.

EUROPE.-Finland: In Ostrobothnia (Lackstrom), Helsingfors (Lindberg), Isl. Åland (Bomansson). Denmark: In Isl. Sjalland (Lange), and Jylland (Jensen). England: Penzance, Cornwall (Curnow); Yanaton Down, Devon, mixed with Sph. cymbifolium (Holmes); Sutton Park, Warwick (Bagnall); Mardale, Westmoreland, and Stockton Forest, York (Stabler); New Forest, Hants (George); Wheeldale, Goathland, York (Braithwaite). Scotland: Strath Garve, Ross, and Isl. Lewis, Hebrides (Braithwaite). Ireland: Near Lough Bray, Wicklow, and Connor Hill, Kerry (Lindberg); in Antrim (Moore).

Of this variety there are two forms, one denser and generally much tinged with ochraceous, which in this country appears to be the most widely distributed state of the species, the other laxer, taller, and entirely green, appears to prefer more shady places, and is well represented by the Sutton Park specimens. Lindberg records that it has also been sent from Java by Teysmann, where it grows among the roots of orchids, and that it is analogous to var. congestum of Sph. cymbifolizm.

\title{
Var. $\gamma$. stenophyllum, LINDB.
}

Plants more or less pale lurid green, short, dense, and irregularly branched. Branch leaves ovate-oblong, less concave and cucullate, and almost entire above.

Synon.-Lindb. Notis. ur Sällsk. pro Fn. et Fl. Fenn. Förh. xiii. p. 40r (1874). Braithw. Monthl. Micr. Journ. May 1873, p. 215 ; et Sphag. Brit. Exsic. n. 6.

$\mathrm{H}_{\mathrm{AB}}$. - In wet bogs and edges of pools.

Europe.-Finland: Isl. Hogland (Lindberg). England: Penzance, Cornwall (Curnow); Staveley, Westmoreland (Barnes); Rowdsey Moss, Ulverston, Lancashire (Miss Hodgson).

This is the rarest form with us, and has not yet been found with fruit; it corresponds to the var. squarrosulum of Sph. cymbifolium. The specimen n. Io in most copies of my Exsiccata is this plant.

\section{Sphagnum cymbifolium (Ehrhart), Hedw.}

\author{
PL. V.
}

Dioicous, pale green, often tinged with purple, the stem with three layers of cuticular cells. Stem leaves smaller, with smaller cells. Branch leaves less rigid, more elongated, their hyaline cells 
smaller, not papillose internally where united to the chlorophyllose cells, which are nearer to the concave surface of leaf.

Perichætial bracts more obtuse, the central cells much smaller and shorter.

Synon.-Muscus terrestris vulgatissimus, PARkinson, Theatr. Botan. p. 1306 (1640).

Muscus palustris terrestri similis, RAY, Cat. Pl. Angl. p. 208 (1670) ; Syn. ed. I, p. $18,9(1690)$.

Muscus palustris in ericetis nascens floridus, Plukenet, Phytogr. i. t. Ior, f. I (169I). RaY, Synops. ed. 1, app. p. 24 I (I6go).

Muscus palustris albicans terrestri similis, capitulis erectis brevibus, pediculis etiam brevissimis insidentibus, RAY, Syn. ed. 2, p. 37, 4 (I696).

Sphagnun caulifcrum et ramosum pahustre molle candicans, reflexis ramulis, foliolis latioribus, Dillen. Cat. Giss. P. 219 (1719), et in Ray, Syn. ed. 3, p. 104, I (1724).

Sphagnum palustre molle deflexum, squamis cymbiformibus, Dill. Hist. Musc. p. 240, t. 32, f. I (I74I), et Herbar. fol. 32, n. I.

Sph. palustre a, L., Sp. Pl. ii. p. I 106 (1753). Huds. Fl. Angl. p. 395 (1762). Fl. Danica, t. 474 (1769). Weiss, Crypt. Götting. p. 263 (1770). Wither. Bot. Arr. Br. Veg. ed. 1, p. 659 (r776). Relhan, FI. Cantab. p. 394, n. 770 ( 1785 ). Siвтн. Fl. Oxon. p. 273 (1794). Аввот, Fl. Bedf. p. 228, n. 743 (1798). Hul, Brit. Fl. pt. 2, p. 245 (I 799). LiNDB. Act. Soc. Scient. Fenn. x. p. 8 (1871).

Sph. palustre cymbifolium, EHRH. Hannov. Mag. r780, p. 235.

Spl. cymbifolium, Hedw. Fund. Musc. ii. p. 86, t. r, f. I (1782). Schrank, 'Baiersch. Fl. ii. p. 434 (1789). Swartz, Musc. Suec. p. 19 (1798). Brid. Musc. Rec. ii. pt. I, p. 2 I (1798); Sp. Musc. i. p. I2 (I8I6); Mant. Musc. p. I (I8I I); Bryol. Univ. i. p. 2 (1826). RöHL. Moosgesch. Deutschl. p. 28 (1800). ScHUltz, Fl. Starg. p. 275 (r806). P. Beauv. Prodr. p. 87 (1805). N. Hsch. St. Bryol. Germ. i. p. 6 (1823). C. Müll. Synops. i. p. 91 (1849). Wils. Bryol. Brit. p. 17 , t. 4 (1855). Sull. Mosses of United States, p. II, n. I (1856). Schimp. Torf. p. 69, t. 19 (1858) ; Synops. Musc. Eur. p. 684 (1860); et ed. 2, p. 847 (1876). LINDB. in Ofv. K. Vet. Ak. Förh. xix. p. I43, n. 14 (1862). Schlieph. in Verh. Z. B. Gesel. Wien, 1865, p. 4r 2. KLingG. in Schr. der K. Phys. CEk. Gesel. zu Königs. I872, p. 9. Milde, Bryol. Siles. p. 395 (1869). Hartu. Sk. Fl. ed. 6, p. 435. HobK. Syn. Br. Moss. p. 23 (1873). Braithw. Sphag. Brit. Exsic. n. 7 and 8 (1877).

Sph. obtusifolium, EhrH. Pl. Crypt. n. 24I (I792). Rотн, Fl. Germ. iii. p. II 8 (1793). Hofrm. Deutschl. Fl. ii. p. 2 I (1795). WEB. MoHr, Bot. Taschen. p. 72 (1807). Schкuhr, Deut. Moose, p. r3, t. 5 (1810). Voit, Musc. Herbip. p. Io (1812). Sturm, Deutschl. Fl. ii. 12. RöHL. Deutschl. Fl. iii. p. 35 (1813). Funck, Samml. n. 229; Moos-tasch. t. 2 (1821). Hook. TAy. Musc. Br. p. 3, t. 4 (1818). MarT. Fl. Cr. Erlang. p. II 7 (I817). Gray, Nat. Arr. Brit. PI. i. p. 709 (I821).

Sph. latifolium, Hedw. Sp. Musc. p. 27 (1801). Turn. Musc. Hib. p. 5 (1804). Sм1тн, Fl. Brit. p. I1 45 (1804); Eng. Bot. t. 1405 (1805). SchwäG. Suppl. I. pt. I, p. 12 (1811). WAhLen. Fl. Lapp. p. 300 (1812); Fl. Carpat. p. 333 (1814). Zenk. Dietr. Mlusc. Thuring. fasc. I, n. I9 (1821).

Sph. vulgare, Michx. Fl. Bor.-Amer. ii. p. 285 (1803).

Dioicous; growing in large masses, usually unmixed with other species, pale greenish white, frequently tinged with purple. 
Stems 6-I 2 in. high, simple or bipartite, robust, reddish brown; cells of the peripheral layers strongly incrassate, brownish red; cuticular cells in 3-4 strata, the innermost being the largest, the external rectangular, fibrose, and with several foramina. Stem leaves reflexed, small, lingulate-spathulate, very slightly fimbriate at the rounded apex; cells all smaller and narrower than in Sph. papillosum, the basal hyaline; fibres and pores usually absent.

Ramuli $4-5$ in a fascicle, 2-3 divergent, arcuate, turgid, acute and attenuated at apex, the others pendent, attenuated, appressed to stem; cuticular cells densely fibrose, rectangular, foraminate, without any mixture of retort cells.

Leaves of divergent branches dense, soft, ovate, deeply concave, more prolonged and a little recurved at apex, which does not differ in colour from the rest of the leaf, and is also less cucullate, more entire and less serrulate than in Sph. papillosum; when dry the margins are often distinctly undulated. Cells much smaller, the hyaline internally never papillose on the periphery, the chlorophyllose subtrigono-ovate, and somewhat nearer to the concave margin of the section.

Perichætial bracts laxer, less cucullate and plicate, rounded obtuse at apex; cells very small in centre of bract, all the lower uniform prosenchymatico-rectangular, with several rows of normal hyaline ones at margin, the upper part bordered by a series of very long narrow cells.

Spores ochraceous. Male plants with short, ochraceous, purplish or olivaceous amentula placed in the coma; the bracts cochleariconcave, resembling the branch leaves in structure.

HAB.-Deep bogs and turbaries in the lowlands. Frequent throughout Europe and N. America. Fr. July.

This species is the type of Linnæus's Sph. palustre, and Lindberg retains the same appellation for it; but since Linnæus referred all the Sphagna to it, I prefer to use the name by which it was first distinguished as a separate species.

This peat-moss is very variable in size and colour, and sometimes forms beds of great extent, free from admixture with other species, but occasionally it may be found growing intermixed with Sph. papillosum, each retaining its distinctive characters. It may generally be distinguished from the latter species by its softer and more attenuated branches, with the leaves of thinner texture, with 
longer and narrower points, and the chlorophyllose cells narrower and quite smooth.

No. $8 b$ of my Exsiccata belongs to Sph. papillosum, and if contrasted with the male plant of Sph. cymbifolium it will be seen that the inflorescence stands out almost free from barren comal branches, while in Sph. cymbifolium they are long and closely surround the male amentula; the colour of the latter species also, generally partakes somewhat of a bluish white tint.

\section{Var. $\beta$. congestum, Schimp.}

Stems $2-5$ in. high, densely tufted in large, compact cushions, pale yellow, bluish red or brownish purple above, intermixed with green, dirty brownish yellow below, somewhat rigid. Stem leaves often fibrose in the upper part. Branches densely crowded, ascending, short, thick, fusiform, their leaves very concave and closely imbricated; pendent ones very slender, often white.

Synon.-Sph. cymbifolium var. congestum, Schimp. Torfm. p. 69, t. xix. f. $\beta$ I ; Synops. p. 685, et ed. 2, p. 848. Braithw. Sphag. Brit. Exsic. n. Io.

Sph. compactum, BRID. Bry. Univ. p. p. (sec. Schimper).

Sph. cymbifolium var. compactum, et var. purpurascens, Russow, Torfm. p. 80.

HAB.-In drier parts of extensive peat-moors, and places cleared of turf. Frequent.

This variety is remarkable for the various tints it assumes, and these are not always preserved by drying, but often become dull blue or brown. It also occurs under two forms; one in extremely dense cushions of large size, as in specimens from Witherslack, Westmoreland, sent by Mr. Barnes; the other laxer, and of a more rosy tint above and pale below, very conspicuous by the abundant heads of deep purple male inflorescence. In some copies of my Exsicc. specimens of Sph. papillosum var. stenophyllum have been placed under No. 1o by mistake.

Var. $\gamma$. squarrosulum, N. Hsch. ST.

Plants slender, in loose dark-green tufts, often with a dingy shade below; divergent branches turgid, loose, their leaves more pointed and patulous, somewhat squarrose, those of the comal branches distinctly squarrose.

Synon.-N. Hsch. St. Bryol. Germ. i. p. 8 (18z3). Brid. Bry. Univ. i. p. 4. Russow, Torfm. p. 80. Braithw. Sphag. Brit. Exsic. n. 9.

Sph. cymbifolioides, BREUTEL, in Regens. Flora, 1824, p. 435. BRID. Bry. Univ. i. p. 749 .

HAB. - In woods and shady banks of ditches. 
This variety is not so frequent as the typical form, into which it gradually passes, and the stem leaves have usually their apical cells fibrose, and with one or two large pores. It sometimes grows intermixed with the true Sph.squarrosum, as in the specimens from Sutton Park, issued in my Exsiccata.

\section{Group B.-SUBSECUNDA.}

Plants soft, slender. Branches terete, their cuticular cells empty ; branch leaves erecto-patent or somewhat imbricated, usually subsecund, ovate, rather obtuse with the apex truncate, the margin involute in the upper half.

\section{Sphagnum tenellum, Ehrhart.}

\section{PL. VI.}

Dioicous, slender, extremely fragile, pale greenish yellow, the stem with two layers of cuticular cells. Stem leaves ovate-oblong, with a broadish border of narrow cells. Branches with large retort cells recurved at neck; branch leaves ovato-lanceolate, 3 -toothed at apex, with a broad border; hyaline cells porose on the upper surface, reticulate-fibrose; chlorophyllose cells triangular, interposed between the hyaline at back.

Synon.-Sph. tenellum, Eнrн. in Herb. Petrop. (1795), teste Lindberg. Hoffm. Deutschl. Fl. ii. p. 22, n. I, in obs. (1796). Persoon, Mss. in Herb. Swartzii. BRID. Mant. Musc. p. I (18I9), et Bryol. Univ. i. p. 4 (1826). RöHL. Moosgesch. Deutschl. i. p. 42. Hartm. Skand. Fl. ed. 9, ii. p. 83 (1864). LindB. in Öfv. K. Vet. Ak. Förh. xix. p. I42, n. I3 (1862). Jensen, in Nat. For. Vid. Medd. 1863 , p. 238 . Fl. Danica, t. 2755 (1867). Hobk. Syn. Br. Moss. p. 23 (1873). Braithw. Sphag. Brit. Exsic. n. II (I877). Non NeEs, Hsch. St. Bryol. Germ., nec Funck, Taschenh.

Sph. cymbifolium var. tenellum, Brid. Musc. Rec. ii. pt. 1, p. 24 (1798). Swartz, Adnot. Bot. p. 71.

Sph. obtusifolium var. tenellum, WEB. MOHR, Bot. Tasch. p. 72 (I807).

Sph. molluscum, BRUCH, in Regens. Fl. 1825, ii. p. 633. Moug. Nestr. St. Crypt. Vog.-Rhen. fasc. 9, n. 808 (1826), cum obs. "Testante cel. Persoon in litt. species a suo Sph. tenello vix ac ne vix diversa." BrıD. Bry. Univ. i. p. 753. HÜ BEN. Musc. Germ. p. 26 (1 833). C. Müll. Syn. Musc. i. p. 95 (1849); Deutschl. Moos. p. 125 (1853). Wils. Bry. Brit. p. 19, t. lx. (1855). Hartm. Skand. Fl. ed. 7, p. 398 (I858). Schimp. Torfm. p. 7 I, t. 2 r (1858); Synops. p. 682 (I860), et ed. 2 , p. 846 (1876). Berkel. Handb. Br. Moss, p. 306 , t. 2, fig. 3 (1863). Milde, Bryol. Siles. p. 394 (1869). Schlieph. in Verh. Z. B. Gesel. Wien, 1865, p. 406. KLINGgR. in Schr. der K. Phys. CEk. Gesel. zu Königs. 1872, p. 9.

Dioicous; in dense soft tufts, pale greenish yellow or tinged with ochraceous above. 
Stems $2-6$ in. high, slender, extremely fragile, simple or bipartite, straw-coloured; cells of the peripheral layers yellowish; cuticular cells in two layers, small, without pores. Stem leaves large, erectopatent or reflexed, ovate-oblong, slightly narrowed toward the point, which has several short, obtuse teeth, minutely auricled; margin incurved, broadly bordered with very narrow elongated cells; hyaline cells in the upper half densely fibrillose with few pores, below narrow and empty.

. Ramuli $2-3$ in a fascicle, $\mathbf{I}-\mathbf{2}$ divergent, short, rather obtuse, pale red; cuticular cells very unequal, smallest quadrate; retort cells large, numerous, recurved, and projecting at the attenuated apex, which is perforated and of a yellow colour.

Leaves of the divergent branches patent or laxly incumbent, sometimes subsecund; broadly ovate or ovato-lanceolate, with $3-5$ small teeth at apex, incurved at margin in the upper part; border of about four rows of extremely narrow elongated cells; hyaline cells broadly rhombic above, three times longer than broad below, all with numerous strong reticulose fibrils, and many small pores on the upper surface; in section the hyaline cells are prominent and confluent on the inner surface, but separated at back by the interposed triangular chlorophyllose cells.

Perichætia placed in the coma and upper fascicles, the bracts large, imbricated, outer oblongo-lanceolate, inner ligulate, densely fibrillose in the upper half.

Capsule globose, small, thin-walled, ochraceous brown; spores sulphur-coloured.

Male plants in distinct tufts, or rarely intermixed with the female and resembling them; amentula small, orange-coloured; the bracts broadly ovate, resembling the branch leaves in structure.

HAB.-Spongy open heaths and wet hollows in hilly places. Fr. May and June.

EUROPE.-Scandinavia; frequent. Sporadically through Silesia, Westphalia, the Black Forest, North Germany, the Vosges, Belgium, \&c. England : Lancashire, Yorkshire, Westmoreland, Sussex, Kent (very fine at Keston Common), and other counties. Scotland: In Perthshire, Forfar, Ross, Kincardine, and other counties ; Shetland at N. Maven (Sim). Irelund: Kerry and other counties (Dr. Moore).

N. AMERICA.-Sparingly in the northern States.

This delicate little Sphagnum is a striking object when in fruit, as this is produced in abundance, and renders it very conspicuous ; while in the barren state it has, no doubt, been frequently overlooked. It is most readily known by the large, curved retort cells 
of the branches, beautiful yellow-green colour, and leptodermous capsules; and it also often grows intermixed with other species. The name tenellum was first applied to this species, we are informed by Professor Lindberg, by Ehrhart, as indicated by a specimen in the St. Petersburg herbarium, and the same species received the same name from Persoon, as proved by a specimen from him, preserved in Swartz's herbarium, and a description is given by Bridel in his Mantissa Musconum (1819); but the plant does not appear to have been well understood by the older authors, as small forms of various species appear under the name tenellum in their herbaria; that figured as tenellum in the Bryologia Germanica evidently belongs to Sph. acutifolium. Bridel also admits Sph. molluscum into the Bryol. Universa, but he only copied the description of Bruch without having seen the plant.

\section{Var. $\beta$. longifolium, LINDB.}

Plants shorter, more densely tufted, with crowded branches, and of a lurid or dingy green colour. Stem leaves longer, the hyaline cells fibrillose throughout. Branches more attenuated, with longer, narrower, and more pointed leaves.

Synon.-Braithw. Sphag. Brit. Exsic. n. I2.

HAB,_Finland: Helsingfors (Lindberg). England: Stansfield Moor, Todmorden (Nowell, r846) ; Carn Galva Moor, Plymouth (Curnow, 186r); Staveley, Westmoreland (Barnes, 1878).

This has a different aspect from the typical state of the plant, owing to its colour being usually of a dirty white; it also appears to be much rarer than the ordinary plant.

Var. $\gamma$. fluitans, Schimp.

Very long and slender, without any pendent branches, all the leaves remote; perichætia scattered throughout the stem, pseudopodia very long.

Synon.-Schimp. Torfm. t. xii. f. 6, 7, 8; Synops. Musc. p. 682.

Sph. molluscum var. $\beta$. immersum, Schimp. Synops. Musc, ed. 2, p. 846 (1876).

HAB. - In stagnant water of the Marais des Ponts in the Swiss Jura (Lesquereux).

\section{Sphagnum laricinum, Spruce.}

Pl. VII. and VIII.

Dioicous, yellowish or pale brownish green; the stem with 2-3 layers of cuticular cells. Stem leaves small, ovato-triangular, minutely fimbriate at apex. Branch leaves subsecund, recurved at point, ovate, pointed, 3-5 toothed at apex; hyaline cells with 
numerous minute pores, chlorophyllose cells central, enclosed by the hyaline, compressed. Perichætial bracts oblong, obtuse, emarginate.

Synon.-Sph. laricinum, Spruce, Mss. r847. WiLs. Bryol. Brit. p. 23, ut synon. (1855). ÅnGSTR. in Öfv. Vet. Ak. Förh. xxi. p. 197 (1864). LindB. in Act. Soc. Sc. Fenn. x. p. 263 in not. et p. $280(1872)$, et in Notis. ur Sällsk. Fn. Fl. Fenn. Förh. xiii. p. 401 (1874). Sulliv. Icon. Musc. Suppl. p. I7, t. 8 (1875). Schliepr. in Verh. d. k. k. Zool. Bot. Gesells. in Wien, 1865, p. 408. Hовк. Synop. Br. Moss. p. 186 (1873). Schimp. Synops. ed. 2, p. 845 (1876). Braithw. Sphag. Brit. Exsic. n. I 3 (1877).

Sph. subsecundum, C. MÜLL. Syn. Musc. ii. p. 539 (1851); spec. bor.-amer.

Sph. contortum, Sull. Mosses Un. St. p. II, n. 3 (1856).

Sph. neglectum, ÅNGSTR, in Öfv. Vet. Ak. Förh. xxi. p. 201 (I864). LiNDB. in Journ. L. Soc. xi. p. 468 (1870). HaRTM. Skand. Fl. ed. Io, ii. p. 124 (1871). Aust. Musc. Appal. p. 7, n. 26 (1870). Braithw. in Monthl. Micr. Journ. Oct. 1872, p. 157, t. 3 .

Sph. curvifolium, Wirs. Mss. Hunt, in Mem. Lit. Phil. Soc. Manch. 3 rd ser. iii. p. 233 (1867).

Dioicous; in lax tufts, pale yellow green, sometimes tinged with rufous above, sometimes olivaceous. Stems $4-8$ in. high, simple or bipartite, pale, the peripheral layers incrassate, rufous; cuticular cells in 2-3 layers, rectangular, without fibres or pores. Stem leaves reflexed, broadly ovate-oblong, moderately auricled, concave, narrowed upward, the apex obtuse and very minutely fringed; margin with a border of extremely narrow cells; the hyaline cells of the upper third of leaf fibrose, with a few minute pores, the rest empty or with a few faintly fibrose at base.

Ramuli $3-4$ in a fascicle, $I-2$ divergent, arched downward at the extremity, the others appressed to stem ; their cuticular cells large, the retort cells cylindric, without any projecting neck.

Leaves of divergent branches when moist laxly imbricated, when dry erecto-patent, subsecund and subfalcate, somewhat glossy, ovate-oblong below, lanceolate-acuminate, the two sides somewhat unequal, very concave, the margin involute in the upper third, bordered by three rows of extremely narrow elongated cells; apex subacute, with $3-5$ minute indistinct teeth; hyaline cells serpentine, elongated, spirally fibrose, with very few small marginal pores ; chlorophyllose cells narrowly elliptic, central, enclosed by the hyaline, strongly compressed.

Fruit seated in the coma, moderately exserted, perichretial bracts oblong, obtuse, scarcely bordered, innermost large, convolute, emarginate, the hyaline cells rather small, lower narrow, upper suboblong with few fibres.

Male amentula short, subclavate, greenish brown, the bracts 
slightly secund, oblong, truncate, with several obtuse teeth, the areolation as in the branch leaves.

HaB. -In deep bogs. Fr. July and August.

Europe.-Finland: Petrosawodsk (Nylander, 1850); Asikkala, Tavastland (Norrlin, 1864); Lafsböle, Åland Isl. c. fr. (Bomansson, 1864). Sweden: Skarpneck, above Kala Berget, Stockholm, c. fr. (1858), by Lake Sandsjön (1853), and at Grycksbo, c. fr. (1854, Lindberg); near Örebro, Nerike, c. fr. (1860), and Skogaholm (1869, C. Hartman); Höör in Skåne (1860, Berggren). Norway: Varstien, Dovrefjeld (1854, Zetterstedt). Livland: Near woods at Techelfer (Girgensohn). Germany: Jungfernhaide, Berlin, c. fr. (Nordmann). England: Terrington Carr, near Welburn, Yorkshire (1846, Spruce); Vale Royal Park, Cheshire (1865), and near Holyhead (Wilson); near Bowness and Barbon Fell, Westmoreland (Barnes). Scotland: Loch Libo, Ayrshire; near Doune, and Glen Falloch, Perthshire (McKinlay).

N. AMErica. - Cranberry Marshes, Northern Ohio, c. fr. (1849, Sullivant); Closter, New Jersey, c. fr. (Austin); Sandlake, New York (Peck).

Closely as this species resembles $S p h$. subsecundum, it may be immediately distinguished from it by a section of the stem, which in the latter species exhibits only a single layer of sharply defined cuticular cells; in Sph. laricinum there are always two strata of these cells, and not unfrequently a third more or less complete series of smaller size is also present. The hyaline cells of the branch leaves are larger and have fewer pores, and the inner perichrtial bracts have the apex obtuse with a distinct notch; the rarity of the fruit, however, prevents the latter character being often available. Angström seems to have confused the plant with Sph. intermedium, as he describes the chlorophyllose cells as trigonous, and free on the dorsal surface of leaf.

\section{Var. $\beta$. teretiusculum, LINDB.}

Stems slender, with large oblong, obtuse leaves, somewhat fringed or toothed at apex. Branches crowded, terete, incurved, or more or less circinate; branch leaves short, very broad, concave.

Svnon.-Sph. subsecundum var. $\beta$. isophyllum, Russ. Torfm. p. 73, p. p.

Sph. neglectum var. Aust. Musc. Appal. p. 7, n. 27.

$S p h$. laricinum var. $\beta$. teretiusculum, LiNDB. in Notis, ur Sällsk. pro Fn. et Fl. Fenn. Förh. xiii. p. 402.

HAB. - In marshy places in woods.

Europe. -Finland: Kroksnäs, near Borgå (186r, Sælan); Reivilä, Hollola (1863, Norrlin); Varesjoki, Ostrobothnia (1872, Lackström). Sweden: Loka, Vestmanland (1854, Hamnström); between Skutijaur and Storavaviken, Lapland ( 1856 , Lindberg); and Nammats, Quickjokk ( 867 , Holmgren). Norway: Nystuedalen, Dovrefjeld (I 865, Berggren). Livland: Techelfer, near Dorpat (Russow).

N. America. - Closter, New Jersey (Austin).

Professor Lindberg states that this corresponds to Sph. subsecundum var. contortum. 


\section{Var. $\gamma$. platyphyllum (SULL.), LiNDB.}

Stems short, with lingulate leaves which are distinctly auricled. Branches short, rather obtuse, with imbricated leaves which are rounded ovate, pointed, very broad and concave.

Synon.-Sph. subsecundum var. $\beta$. isophyllum, Russ. Torfm. p. 73, p. p.

Sph. platyphyllum, n. sp. ? vel. var. Sph. neglecti? Suli. Mss. Dec. r868.

Sph. cochlearifolium, Wils. Mss. in Herb. suo (Mus. Brit.).

Sph. laricinum var. platyphyllum, LiNDB. in Notis. ur Sällsk. pro Fn. et Fl. Fenn. Förh. xiii. p. 403 (1874). Bralthw. Sphag. Brit. Exsic. n. r $_{4}$ (I877).

HAB.-In peaty places, among short grass. Rare.

Europe.-Finland: Hardom, in Nyland (Arrhenius, r868) ; Asikkala, in Tavastland (Norrlin, r864); Sarvivaara, in Ostrobothnia (Lackström); Karesuanto, in Lapland (Norrlin, 1867). Sweden: Olsbacka, in Gestrikland (R. Hartman, r855); Grycksbo, in Dalarne (Lindberg, r854); Norrlunda, Lapland (J. Angström, 1860). Norway: Ullensager, Romerige, c. fr. (Blytt); Sogndalsvand (Wulfsberg, 1867); Nystuhöe, Dovrefjeld (Berggren, r865). Esthland: Seewald, Reval (Russow). Scotland: Perthshire, shore of Loch Katrine (Mr. Lyle, 1852 ); Ben Ledi (Dr. Stirton). Wales: Top of pass between Aber and Llanwrst (Professor Lawson, r874).

N. America.-New Jersey (Sullivant).

This corresponds to var. auriculatum of Sph. subsecundum, and is usually more stunted in growth than the other forms of the species.

\section{Var. $\delta$. cyclophyllım (SUlL. LeSQ.), LiNDB.}

Stems short, turgid, $I-4$ in. long, quite simple or with one or more short solitary branches, pale and glaucous. Stem leaves very large, widely orbicular-ovate, flaccid, deeply concave. Capsules small, globose, immersed in a lateral bud-like perichætium; the bracts oblong-ovate, concave, eroso-truncate at apex.

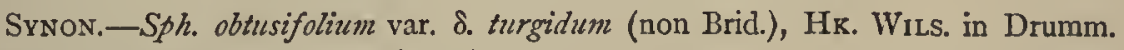
Musc. Bor.-Amer. ser. 2, n. 17 (r84r).

Sph. cyclophyllum, Sull. Lese. Musc. Bor.-Amer. ed. I, n. 5 (1856). Sull. Mosses of Un. St. p. I I, n. $7(1856)$; Icon. Musc. p. I3, t. 6 (1864), et id. Suppl. p. r6, t. 7 (1874). Austin, Musc. Appal. p. I r, n. 25 (1870).

Sph. subsecundum var. $\gamma$. simplicissimum, MrLDE, Bryol. Siles. p. 393 (1869)?

Sph. Drummondii, WiLs. Mss. in Herb. suo (Mus. Brit.).

HAB.-Wet mountain heaths.

Europe.-Finland: Eckerö, in the Aland Islands (Reuter and Elfving, $187 \mathrm{r}$ ). Silesia: Kuhplan, near Langwaltersdorf and Görbersdorf (Milde)?

N. AMERICA.-New Orleans (Drummond); mountains of Alabama (Lesquereux); New Jersey (James) ; Southern New Jersey, c. fr. (Austin).

This variety corresponds to Sph. subsecundum var. obesum, and differs so completely in aspect from the typical state that few botanists would refer them to the same species; some of the 
Finland specimens, however, distinctly show the transition between it and the var. platyphyllum, while the structure of the stem and leaves agrees perfectly with that of the other forms, and thus confirms the accuracy of Professor Lindberg's diagnosis. Milde's plant is doubtfully referred here by Lindberg, and it is very desirable that original specimens should be examined, as Mr. Boswell sends me a form of Sph. subsecundum, which is almost equally free from branches; this may possibly be a seedling condition, growing with closely aggregated stems, and identical with Milde's specimen.

\section{Sphagnum subsecundum, NeEs, v. EsEnb.}

\section{PL. IX. AND X.}

Dioicous, dull green, olivaceous or rufescent; the stem dark brown, with a single layer of cuticular cells. Stem leaves small, broadly ovate, very minutely fimbriate at apex. Branch leaves more or less subsecund, broadly acuminato-elliptic, 3-5 toothed at apex; hyaline cells very small, with numerous minute pores at margins; chlorophyllose cells central, enclosed by the hyaline, compressed. Perichætial bracts oblong, acutely pointed.

Synon.-Sph. subsecundum, NeEs, in Sturm's Deutschl. Fl. Crypt. fasc. I 7 (1819). Funck, Moos-Taschenherb. p. 4, t. 2 (1821). NeEs et Hornsch. Bryol. Germ. i. p. I 7 , t. 3, f. 7 (1823). BRID. Bryol. Univ. i. p. 8 (1826). HÜBEN. Musc. Germ. p. 26 (1833). C. MÜLL. Synops. i. p. 100 (1849). Schimp. Torfm. p. 74, t. 22 (1858); Synops. p. 682 (1860), et ed. 2, p. 843 (1876). Linde. in Öfv. K. Vet. Ak. Förh. xix. p. I4I, n. II (1862). HarTM. Skand. Fl. ed. 9, ii. p. 82 (1864). Russow, Torfm. p. 7 I (1865). Schlieph. in Verh. Z. B. Gesel. Wien, 1865, p. 406 . Fl. Danica, t. 2754, excl. f. 6 et v. (1867). KuINGG. in Schr. der K. Phys. CEk. Gesel. zu Königs. 1872, p. 8. MiLDE, Bryol. Siles. p. 392 (1869). BRAithw. Sphag. Brit. Exsic. n. 15 (1877). Hовк. Syn. Br. Moss. p. 25 (1873).

Sph. contortum var. $\beta$. subsecundum, WILs. Bry. Brit. p. 22, t. lx. (I 855).

Dioicous ; tall, slender, in soft tufts of various colours, glaucous green, yellowish green, brownish or ochraceous. Stem solid, brown or blackish, somewhat glossy, with a single thin layer of cuticular cells without pores; those of the peripheral layers deep brown. Stem leaves small, from a broad base, broadly ovate, minutely auricled, cucullate at apex, but finally flattened, and very minutely fringed; bordered by four rows of extremely narrow cells; upper hyaline cells broader, densely fibrose and porose, the lower longer and narrower without fibres and pores, or sometimes furnished with them to the base.

Ramuli about four in a fascicle, 2-3 arcuato-patulous, I-2 
pendent, less elongated, not appressed to stem, the retort cells perforated at the slightly recurved apex. Leaves of the divergent branches laxly incumbent or patent, more or less secund and subfalcate at apex, broadly elliptic, acuminate, very concave, with the margin involute in the upper half, narrowly bordered, the point with 3-5 small teeth; hyaline cells very small, flexuose, elongated, with annular and spiral fibres, and numerous minute pores in a row at each margin; chlorophyllose cells enclosed by the hyaline, central, strongly compressed.

Fruit usually seated in the capitulum ; perichætial bracts laxly imbricated, elongate oblong, acuminate, fibrose, and with a few pores in the upper part. Spores ferruginous.

Male plants more slender, in distinct tufts; the amentula short, olive green or rufescent; the bracts broadly ovate, acute, with incurved bordered margins.

HAB.-Wet heaths and ditches. Fr. July.

EUROPE.-Generally distributed, but not very frequent; Scandinavia, Germany, Silesia, Belgium; Westmoreland, Skeggles Water (Barnes), Bowness (Hunt), Devonshire (Holmes)

N. AMERICA.-Not common.

Sph. subsecundum grows in loose tufts, which are often of great size, and is chiefly remarkable for the multiplicity of forms under which it presents itself as well as for the variety of hues with which these are tinted, embracing deep green, every shade of yellow, ochraceous or brownish green, and various tints of claret colour. The typical form of the species appears to be the most uncommon, and is also rare in fruit.

Protean as this plant undoubtedly is, there need never be any difficulty in its determination, for it is the only European species with a single layer of cuticular cells to the stem; the latter is generally of a very dark brown or black colour, and shines conspicuously through the branches when in a moist state.

Var. $\beta$. contortum (Schultz), Schimp.

Robust, more or less immersed, yellowish green, tinged generally with claret colour, ferruginous, ochraceous, or olivaceous. Ramuli crowded, terete, the upper usually more or less circinate.

Stem leaves large, fibrose. Branch leaves very large and broad, closely imbricated, not secund, or slightly so when dry, 
somewhat glossy, the chlorophyllose cells less compressed, the apex with five or six larger teeth.

Synon.-Sph. contortum, SchulTz, Suppl. Fl. Starg. p. 64 (18 i g). NeES, Hsch. ST. Bry. Germ. i. p. 15, t. 2, f. 6 (1823). BRId. Bry. Un. i. p. 7 (1826). Wils. Bry. Br. p. 22, pl. 60 (I855). Suld. Moss. Un. St. p. I I n. 3 (I856). Berkel. Handb. p. 308 (I863). KLingG. in Schr. der K. Phys. CEk. Gesel. zu Königs. 1872, p. 8.

- Sph. Lescurii, Suld. Musc. Bor.-Amer. n. 6 (1856); Mosses of Un.St. p. I I, n. 4.

Sph. subsecundum var. contortum, Scrimp. Torm. p. 75 , t. xxii. $\beta$ et xxiii. $\beta$; Synops. p. 683 , et ed. 2, p. 844 . MildE, Bry. Siles. p. 393. Braithw. Sphag. Brit. Exsic. n. 16,17 .

Sph. latifolium var. B. fluitans, TuRn. Musc. Hibern. p. 5 (1804).

Sph. subsecundum var. rufescens, N. H. ST. Bry. Germ. i. p. 16, t. 2, f. 6*. BRID. Bry. Un. i. p. 8. HüBEN. Musc. Germ. p. 26.

Sph. subsecundum var. isophyllum, Russow, Torf. p. 73, p. p.

HAB.-Ditches in peat-bogs and at margin of pools; frequent throughout Europe and N. America.

This variety is perhaps the most polymorphous of all the Sphagna, and in some form or other may generally be met with. Occasionally it is very large, and presents an intermediate stage to the var. obesum; in others the branches are not contorted or but slightly so in those of the capitulum, or they may be short, ascending, and of equal length throughout.

Mr. Boswell sends a curious form, which he found floating in a spring on Mitcheldean Meend, Gloucester: in this the upper branches are abbreviated, and the rufescent leaves clustered upon them into a rosette shape. Another, collected by Rev. Aug. Ley, at Trelleck Bog, Monmouth, has the stems quite simple or with a few solitary branches, and very long lax leaves: this he regards as probably the var. simplicissimum, MILDE.

\section{Var. $\gamma$. auriculatum (Schimp.), LindB.}

Plants glaucous green above, pale below; the stems pale brown or green. Cauline leaves large, lingulate-acuminate, subhastate at base, with large auricles composed of large fibrose utricular cells, free and perforated at the apex.

Sph. auriculatum, Schnмp. Torfm. p. 77, t. xxiv. (1858); Synops. p. 687 (1860), et ed. 2, p. 844 (1876).

Spl. cymbifolizin var. $\gamma$. tenellum, HarTM. Skand. Fl. ed. 7, p. $39^{8}$ (I858).

Spk. subsecundum var. autriculatum, LiNDB. in Öfv. K. Vet. Ak. Förh. xix. p. I4I (1862), in obs. sub. n. Ir. Schliep. in Verh. Z. B. Gesel. Wien, 1865, p. 4 II. Braithw. Sphag. Brit. Exsic. n. 19, 20.

$\mathrm{HAB}_{\mathrm{B}}$ - At the margins of pools on heaths.

Europe.-England: Hayward's Heath, Sussex (Mitten); Sutton Park, Birmingham (Bagnall); Witherslack Moss, Westmoreland (Barnes); Lindow Common, 
Mobberley, Cheshire (Whitehead, 1876) ; Eskdale old alum works, Whitby, Yorkshire (Anderson). Lapland: At Lycksele (Ångström), and Pitea (Sxelan). Finland: Mt. Hunneberg, and at Loka, in Westmanland (Hamnström); at Olsbacka (Hartman); Grycksbo, in Dalarne (Ångström); Isl. Fyen, at Hofmansgave (Hofman-Bang).

Although this plant is still retained as a species by Professor Schimper, there cannot be the slightest doubt that it belongs to the series of forms referable to Sph. subsecundum. The stipules or auricles are most variable in size and structure, and in this species no two forms possess them in the same degree of development. Besides the ordinary state, an immersed form occurs which sometimes grows to a large size, and differs in its deep green colour and weak flabby branches, which collapse when removed from the water.

\section{Var. $\delta$. obesum, WiLs.}

Plants very robust, pale green, tinged with reddish brown. Branches swollen, obtuse; branch leaves large, very broad, truncate at apex and 5-toothed, closely imbricated. Stem leaves very large, ovate, fibrose in upper part, or sometimes throughout.

Syxon.-Sph. contortum var. $\gamma$. obesum, WiLs. Bry. Brit. p. 22 (1855).

Sph. subsecundum var. $\gamma$. obesum, Schimp. Synops. ed. 2, p. 844 (1876). Brarthw. Sphag. Brit. Exsic. n. I8.

Sph. subsecundum var. turgidum, C. Müı.. Synops. i. p. Ior. Schlieph. 1. c.

Sph. denticulatum (Movg. NeSTL.), Bridel, Bry. Univ. i. p. Io.

HAB.-In deep pools and ditches. Not common.

Europe. - England: Alderley, Cheshire (IVilson); Carn Galva Moor, Penzance, Cornwall (Curnow); Darnholm, Goathland, Yorkshire (Anderson). Scotland: Glen Prosen, Forfar (Rev. J. Fergusson). Germany: Pegnitz, in Franconia (Arnold); Kiebitz Bog, near Halle (Schliephacke).

The most robust of all the forms, and in deep water attaining a great length. It is generally of a dirty reddish-brown colour, and the fruit is rare and usually produced about the middle of the stem.

\section{Group C.-TRUNCATA.}

Plants densely ramulose, forming compact cushion-like tufts. Branch leaves erecto-patent, broadly oblong-lanceolate, with the apex truncate and toothed; the margin involute for nearly all its length.

\section{Sphagnum Ångströmii, C. Hartm.}

PL. XI.

Dioicous; robust, pale green. Stem pale, with three layers of cuticular cells, densely ramulose. Stem leaves obovate-lingulate, the apex truncate, and slightly fimbriate. Branch leaves broadly 
ovate-acuminate, truncate, with 6-10 minute teeth; the chlorophyllose cells central, compressed. Perichætial bracts ovateoblong.

Synon.-Sph. Angströmii, C. Hartm. Skand. Fl. ed. 7, p. 399 (1858). LindB. in Öfv. K. Vet. Ak. Förh. xix. p. 140, n. 10 (1862). Schimp. Synops. ed. 2, p. 842 (1876). BraIthw. in Monthl. Micr. Journ. July, 1873, p. 14, pl. xxii.

Sph. cymbifolium var. $\beta$. cordifolium, HARTM. op. cit. ed. $3^{-6}$ p. p.

Sph. insulosum, Ångstr. Mss. Schpr. Synops. p. 683 (1860). Milde, Bryol. Siles. p. 390 (1869). Schlieph. in Verh. Z. B. Gesel. Wien, r865, p. 405.

Dioicous; in large, soft, dense, pale green tufts, light brownishyellow below. Stems simple or dichotomous, 6-10 in. high, whitish, with three layers of thin cuticular cells, free from fibres and pores; cells of the peripheral layers yellowish white. Cauline leaves broadly obovate-lingulate, minutely auricled, the apex truncate and slightly eroso-fimbriate; hyaline cells in upper half rhomboid, at middle base flexuose-rhomboid, thence to margins very narrow, flexuose-linear, free from pores and fibres, or with a few faint fibres in the upper part.

Branches crowded, $3-5$ in a fascicle, $\mathrm{I}-2$ patulous, arcuatodecurved, the rest slender, greatly elongated, appressed to stem; the retort cells small, cylindric, perforated at the scarcely projecting apex.

Ramuline leaves densely crowded, indistinctly 5-ranked, when moist turgidly imbricate, when dry erecto-patent, opake, concave, widely ovate-acuminate; the apex broadly truncate, with 6-10 minute, unequal, obtuse teeth; the margin incurved in the upper two-thirds, and with a faint border of two rows of extremely narrow cells; the hyaline cells annulate-fibrose, minutely and sparingly porose, the chlorophyllose cells enclosed by the hyaline, much compressed; leaves of the pendent branches with the apex rounded and indistinctly toothed. Capsules seated in the coma or upper fascicles, on a thickish white peduncle; the perichrtium inflated, oblong, whitish; lower bracts ovate-acuminate, muticous, middle broadly ovate-oblong, innermost broadly oblong, deeply concave and often cucullate at apex, all with very narrow linear areolation, quite free from fibres and pores. Spores ferruginous. Male plants growing in the same tufts with the female, more slender, the amentula short, ovate, closely imbricated, pale green, crowded in the coma; bracts roundish ovate, in the lower part of lax wide curved non-porose cells, often free from fibres, 
becoming denser, fibrose, and porose toward the broadly truncate tọothed apex.

$\mathrm{HAB}_{\mathrm{A}}$-Deep marshes in the north of Europe, forming great tufts in the water, like islands. Fr. July.

EUROPE.-Karesuando, in Tornean Lapland (Lrestadius, 1825); Lycksele, in Lulea Lappmark (Ångström, 1858); also in Pitean Lapland, between Lakes Skutijaur and Storavaviken, and in many places in Umean Lapland (Angström). Finland: At Kajana (Malmgren); Ruovesi (Simming), and Sarvivaara, in Ostrobothnia (Brotherus). Norzeay: Drivstuen, in the Dovrefjeld (Berggren).

This fine species has not much affinity with either of those with which it is grouped, nor indeed with any others; in aspect it most reminds us of Sph.cymbifolizm, from which it is at once distinguished by its toothed branch leaves and non-fibrose cuticular cells.

It has not yet been found in America.

\section{Sphagnum molle, Sullivant.}

\section{PL. XII.}

Monoicous ; in very soft, dense tufts, whitish green above, pale brown below. Stem with 2-3 strata of cuticular cells. Stem leaves large, obovato-spathulate, 3 -toothed at apex, very narrowly bordered; the hyaline cells fibrose and porose in the upper part. Leaves of divergent branches oblong-ovate, convolute above, the apex truncate, with 5-6 irregular teeth; hyaline cells prominent and confluent at back, the chlorophyllose triangular, projecting between the hyaline at the concave surface of leaf.

Svnon.-Sph. molle, Sull. Musci Allegh. n. 205 (1845); Mosses of Un. St. p. I3, n. I4 (1856); Ic. Musc. p. 7, t. 4 (1864).

Sph. tabulare, Sull. Musc. Allegh. n. 204 ; Mosses of Un. St. p. 12, n. 13.

Sph. compactum S. ramulosum, C. MüI.L. Syn. Musc. ii. p. 539 (185 I).

Monoicous or dioicous? growing in soft, densely cushioned tufts ; yellowish green or whitish green above, pale brown below. Stem 3-5 in. high, pale green, slender, with 2-3 layers of non-porose cuticular cells, those of the peripheral layers pale yellowish. Stem leaves large, closely set, obovate-spathulate, minutely auricled, patent and deflexed; the margin involute above, very narrowly bordered; apex with three teeth and a few smaller ones below; hyaline cells weakly fibrose in the upper third.

Ramuli crowded, 3-4 in a fascicle, nearly alike, short, slender, divergent or ascending; the retort cells elongated, a little recurved at apex. Branch leaves divergent or subsquarrose, oblong-ovate, 
concave, convolute above, very narrowly margined; the apex truncate, and with 5-6 irregular teeth; the hyaline cells angulatofusiform, very prominent and confluent at the back, with annular and spiral fibres, and a few large pores; chlorophyllose cells slender, triangular, projecting between the hyaline at the concave surface of leaf. Capsules in the capitulum or upper fascicles, perichrtium not separating, the upper bracts broadly oblong-ovate, convolute, with 2-3 irregular teeth at apex, the lower cells elongate hexagono-rhomboid, the upper normal, free from fibres and pores.

Male amentula short, thick, purple, placed in the coma; the bracts oblong, obtuse.

HAB.-By moorland streams and sandy springs.

N. AMERICA.-Mountains of N. Carolina (Gray); Tallulah Falls, Georgia (Lesquereux).

Professor Lindberg was the first to identify Sph. Mülleri with the American $S p h$. molle, and undoubtedly they only constitute a single species, yet, as certain differences exist between them, I have deemed it best still to maintain Sph. Mülleri as a variety.

Taking the original plant issued in the Musci Alleghanienses as the type, it presents a different aspect to Sph. Mülleri in that its branch leaves are shorter, broader, more divergent, and slightly squarrose, the stem leaves without fibres in the lower half, and the plants more rigid and of a greener colour. The specimens are without fruit, but, according to Sullivant's figure, the apex of the perichrtial bracts is truncate and not acutely acuminate. As to the dioicous position of the inflorescence, it is probable that some error exists, as in Sph. Mülleri the male amentula are certainly very rare, and appear to be of short duration; I have observed them in specimens received from Mr. Sim, and in these they were very short, and of a rich purple colour.

That Sullivant did not clearly understand his plant is evident, as, in his two Exsiccata, forms of Sph. molle are referred to four different species.

Var. $\beta$. Muelleri (Schimp.), Braitin.

Pale whitish green, soft. Branches longer, patulous or ascending, the pendent branches slender, short. Stem leaves more elongated, the hyaline cells strongly fibrose and porose except near 
the base. Branch leaves longer, oblong-lanceolate. Perichatial bracts lanceolate, acuminate, the apex with 4-5 irregular teeth, hyaline cells fibrose.

Synon.-Sph. molluscoides, C. Mülc. Synops. i. p. 99 (1849).

Sph. Milleri, Schimp. Torfm. p. 73, t. 26 (1858) ; Synops. p. 686 (1860), et ed. 2, p. 841 (1876). LiNDB. in Öfv. K. Vet. Ak. Förh. xix. p. 140, 11. 9 (1862). Suldiv. Ic. Musc. p. 9, t. 5 (1864). Russow, Beitr. zur Kennt. Torfm, p. 78 (1865). SchliepH. in Verh. Z. B. Gesel. Wien, 1865, p. 403 .

Sph. molle, Lindb. in Öfv. K. Vet. Ak. Förh. xx. p. 414 (1863). Mrlde, Bryol. Siles. p. 39 r (1869). Braithw. Sphag. Brit. Exsic. D. 2 I (1877).

HAB.-By moorland streams, forming small dense hassocks. Fr. August.

EURope. - Near Jever, in Oldenburg, and at Detmold (C. MǗlLER); Estrup, in Jylland, Denmark (Lange, 1853); Hofmansgave, in Fuen (Hofinan-Bang, I861); Höor, in Scania (Berggren) ; Mt. Hunneberg, in Westergöthland (Lindberg); Silesia ; Holland; heaths near Dellbrück and Höxter, in Westphalia; Aurich, in Friesland; near Baireuth (Arnold). England: Darnholm, Goathland, Yorkshire (Anderson, r 853); Brickhill Heath, Bucks (Rev. J. F. Crouch); Rowdsey Moss, Ulverston, Lancashire (Miss Hodgson). Scotland: Ben Lawers (MacKinlay); about Strachan and Banchory (Sim). Shetland: At N. Maven and in Unst (Sim).

N. AMERicA.-Mobile (Sullivant).

This plant is probably not uncommon with us, but has doubtless been passed over as a form of Sph. acutifolinu, from which it may be at once distinguished by its large fibrose stem leaves, which want the wide border of narrow cells, so well marked in that species; but the barren specimens in some copies of my Exsiccata are truly Sph. acutifolium.

\section{Var. $\gamma$. tenerum (Sull. LesQ.), Braithw.}

Stems I-2 in. high, densely cæspitose, of a dirty white or yellowish colour. Branches closely crowded, erecto-patent, their leaves acuminate, somewhat undulate at margin. Perichætial bracts lanceolate, acuminate, broadly bordered above, fibrillose in the middle, irregularly $4-5$ toothed at apex.

Synon.-Sph. acutifolizm var. ? Suld. Musc. Allegh. n. 203 (r 845).

Sph. tenerim, Sull. LesQ. Musc. Bor.-Amer. n. I i ; Mosses of Un. St. p. I I, n. 5 . Sph. tabulare, Suld. LesQ. Musc. Bor.-Amer. n. I5 (1856); Mosses of Un. St. p. I 2, n. $13(1856)$.

Sph. molle var. arctum, Braithw. Sphag. Brit. Exsic. n. $2 \mathrm{I}^{*} c$.

HAB.-In drier places among decayed peat.

N. America.-Table Mountain, N. Carolina; Mobile, Alabama.

Europe.-England: Darnholn, Goathland, Yorkshire (Braithwaite). Seotland: Dalfroo Bog, Strachan, Kincardine, in fine fruit, growing with Sph. rigidum var. compactum (Sin, Aug. 1878). 
This is the compact form of the species, and is always of small size and dingy hue. It strangely got mixed in my Exsiccata with Sph. acutifolium var. arctum, from which it may be readily distinguished by the structure of the stem leaves.

\section{ro. Sphagnum rigidum (N. v. Esenb.), Scirpr.}

PL. XIII.

Monoicous; in dense whitish tufts, tinged with glaucous green or rufous. Stem with 2-3 strata of cuticular cells. Stem leaves very small, broadly ovate, the apex rounded, erose. Leaves of divergent branches, ovate-oblong, very concave; the margin inflexed; the apex truncate and toothed; hyaline cells reticulose fibred, the chlorophyllose central, compressed.

Synon.-Sph. compactum B. rigidum, NeEs, Hsch. St. Bryol. Germ. i. p. I4, t. 2, f. $5^{*}$ (1823). BRID. Bryol. Univ. i. p. I7 (1826). C. MÚll. Synops. i. p. 99 (1849.

Sph. immersum, Nees, Hsch. St. Bry. Germ. i. p. II, t. 2, f. 4. BRID. Bry. Univ. i. p. 9.

Sph. ambiguum, HüвеN. Musc. Germ. p. 25 (1833).

Sph. rigidum, Sch1mp. Torfm. p. 65, t. I8 (1858); Synops. p. 678 (1860), et ed. 2, p. 839 (1876). Lindb. in Öfv. K. Vet. Ak. Förh. xix. p. 139, n. 8 (1862). Russow, Torfm. p. 77 (I865). Milde, Bryol. Siles. p. 390 (I869). Hartm. Skand. Fl. Schlieph. in Verh. Z. B. Gesel. Wien, r865, p. 401. KlingG. in Schr. der K. Phys. OEk. Gesel. zu Königs. I872, p. 9. Braithw. Sphag. Brit. Exs. n. 23 (1877).

Monoicous; in dense, rather rigid tufts, glaucous green above, whitish below. Stems erect, dark brown or blackish, 4-10 in. high, densely ramulose, usually 2 , sometimes 3-4 partite; cuticular cells small, non-porose, in 2-3 strata; cells of the peripheral layers dark reddish brown. Stem leaves minute, erect, inserted obliquely, from a broad base, ovate, or obtusely triangular, with a rounded erose apex, minutely auricled; areolation lax and rhomboidal in the middle, with a broad border of thin narrow cells, all without fibres or pores, or with the apical cells fibrose and porose, and a few fibres in the basal cells.

Ramuli 3-4 in a fascicle, short, I-2 erecto-patent, obtuse, the others flagelliform, slender, lax-leaved; cuticular cells larger, the porose scarcely distinct from the rest. Leaves of the divergent branches quinquefarious, from an ascending base, erecto-patent, rigid when dry, ovate-oblong, very concave, somewhat cucullate at apex, but when flattened out, more or less truncate and obtusely 
toothed; margin inflexed; hyaline cells wide, reticulose fibred, with many unequal pores, the marginal narrow, in two rows, the outermost having a longitudinal furrow at the edge; chlorophyllose cells enclosed by the hyaline, central, compressed; leaves of the pendent branches elongated, narrower, more distant, and imbricated.

Perichretia gemmiform, somewhat curved, not expanding; the bracts ovate and oblongo-lanceolate, subfalcate above; apex with two teeth, cells with fibres and minute pores as in the branch leaves.

Capsule rather small, immersed, or moderately exserted. Spores ochraceous.

Male inflorescence not amentaceous, but with the antheridia scattered on the pendent branches; not numerous, yellowish.

HAB.-Marshy heaths and moorlands, and wet mountain slopes. Generally distributed in Europe and North America, but not frequent. Fr. July.

Rare in Lapland, but very fine and fertile, attaining a height of one foot or more (Lindberg). Near Arlary, Kinross, Scotland (Dr. Greville). Linwood Warren, Lincolnshire (F. A. Lees); Canford Heath, Poole, Dorset (Boswell).

The tall highly-developed state of the plant is very wisely selected by Schimper to stand as the type of this species, and the name compactum retained for the short dense form more or less represented in every species of Sphagnum; between the extreme states we have a gradual series of transition forms which imperceptibly connect one with the other. A remarkable peculiarity is presented by this species in its perichrtial leaves, the areolation of which accords with that of the branch leaves, instead of with that of the stem leaves as is almost always the case. The fruit is rare with us, but Dr. Greville's specimens from Arlary bear it in abundance.

\section{Var. $\beta$. compactum (DE CAND.), Schimp.}

Plants short, $\mathrm{I}-3$ in. high, in very dense cushioned tufts; branches densely crowded, erect, short, thick and compressed, their leaves rounded at apex. Colour pale rufescent, dirty white or pale green, variegated with rufous. Capsules immersed.

Syron.-Sph. compactum, DE CAND. Fl. Franc. ii. p. 443 (1805). BRid. Sp. Musc. p. 18 (1806); Mantis. p. 3 (18rg); Bryol. Univ. i. p. 16 (1826). SchwäGR. Supp. I. pt. I, p. I 2, t. 3 (1811). Funck, Moos-tasch. p. 4, t. 2 (182 I). C. MÜLL. Synops. i. p. 98 (1849). Wils. Bryol. Brit. p. I8, t. 61 (I855). Sulz. Mosses of 
Un. St. p. II, n. 2 (1856). Berkel. Handb. Br. Moss. p. 306, t. 2, f. 2 (I863). HoBkIRK, Syn. Br. Moss. p. 23 ( 1873 ).

Sph. condensatum, Scrileich. Pl. Crypt. Helv. cent. 2, n. 5 (i 804).

Sph. obtusifolizm $\beta$. condensatum, WEB. MoHr, Bot. Tasch. p. 73(1807). RöHLing, Deutschl. Fl. iii. p. 35 (1813).

Sph. helveticum, SchkuHr, Deutsch. Moos. p. 12, t. 3 (1810).

Sph. obtusifolizm B. mimus, Hook. TAyl. Musc. Br. p. 3(18IS). Gray, Nat. Arr. Brit. Plants, p. 710 ( $182 \mathrm{r}$ ).

Sph. pramorsum, ZeNker, Dietr. Musc. Thuring. fasc. I, n. I8 (I82I). BRin. Bry. Univ. i. p. i7 (ut var. S. compacti).

Sph. rigidum var. compactum, Schimp. Torfm. p. 66 (1858); Synops. p. 678. Russow, Torfm. p. 77. Milde, Bryol. Siles. p. 391. KlingGräfF, l. c. Braithw. Sphag. Brit. Exsic. n. 25.

$\mathrm{H}_{\mathrm{AB}}$ - On drier heaths and moors. Frequent throughout Europe and N. America. Not uncommon in the south of England, as on the Sussex Downs, and on Oxshot Common, Surrey.

This form of the species is much the commonest with us, and varies greatly in colour, being sometimes almost entirely rufous brown; the fruit is also not unfrequent in some seasons. As is usually the case in the dense growing varieties of the Sphagna, the stem leaves have the hyaline cells frequently fibrose.

Var. $\gamma$. squarrosum, Russow.

Plants pale green, in loose tufts, 3-6 in. high. Branches more distant, spreading horizontally or decurved; their leaves loose and squarrose. Perichæetial bracts shorter.

Synon.-Sph. strictum, Sull. Musc. Allegh. n. 20 I (1845). C. MüLl. Synops. i. p. I04.

Sph. humile, Schimp. Suld. Musc. Bor.-Amer. n. I4; Mosses of Un. St. p. II, n. 6 (1856).

Sph. rigidum var. squarrosum, Russow, Torfm. p. 77. MiLDE, Bry. Siles. p. 39r. Braithw. Sphag. Brit. Exsic. n. 24.

HAB.-Shady parts of subalpine heaths.

EUROPE.-Techelfer Woods, near Dorpat (Russow); Bunzlau (Limpricht); Weissenfels, in Thuringia (Schliephacke). England : Langdale, Westmoreland (Barnes); Darnholm, Goathland, Yorkshire (Anderson).

N. America.-Tallahassee, Florida (Regel) ; Look-out Mountains, Alabama (Lesquereux); Carolina (Sullivant).

A very beautiful plant, of softer texture than the type, but connected with it by intermediate states which vary in the degree of squarrosity in the branch leaves.

\section{GROUP D.-CUSPIDATA.}

Plants rather rigid, loosely tufted. Branch leaves erecto-patent, lanceolate, acute or acuminate, truncate and toothed at apex; margin more or less bordered, involute at point. 


\section{Sphagnum squarrosum, Persoon.}

PL. XIV.

Monoicous or dioicous; green, the stem reddish, with two strata of cuticular cells. Stem leaves lingulate, not bordered; the apex rounded and slightly fimbriate. Branch leaves squarrose, broadly ovate below, suddenly lanceolate; the apex minutely 3-4 toothed; bordered with very narrow cells; chlorophyllose cells compressed, enclosed by the hyaline. Perichrtial bracts obovate, emarginate.

Synon.-Sph. squarrosum, Pers. Mss. Crome, Samml. Deutsch. Laubm. i. p. 24, n. 3 (1803). Wer. MoHR, Naturh. Reise durch Schweden, p. 29, t. 2, f. I a et b (I804), et Bot. Tasch. p. 73 (r807). Surrth, Eng. Bot. t. 1498 (1804). P. DE Beauv. Prodr. p. 88 (1805). La Marck et Cand. Fl. Franc. i. p. 443 (1805). SchUltz, Fl. Stargard. p. 276 (r806). BRID. Sp. Musc. i. p. 44 (1806); Mantissa, p. 2 (18I9), et Bry. Univ. i. p. 5 (1826). RöHL. Ann. Wetter. Gesells. i. p. 197 (1809), et Deutschl. Fl. iii. p. 36 (1813). Schkuhr, Deutschl. Moose, p. 14, t. 6 (r8io). Fl. Danica, t. r4 5 (I8ro). Schwägr. Suppl. I. pt. I, p. I3, t. 4 (18Ir). VoIt, Musc. Herbip. p. I 2 (1812). Hoox. Tayl. Musc. Brit. p. 4, t. 4 (1818). Funck, Taschenh. t. 2 (182r). Gray, Nat. Arr. Br. Pl. i. p. 7 ro, 2 (1821). Zenk. Dietr. Musc. Thuring. n. 21 (1 82 r). NEES, Hsch. St. Bry. Germ. i. p. 9, t. I, f. 3 (1823). Hüben. Musc. Germ. p. 23 (1 833). De Not. Syll. Musc. Ital. p. 295 (1 838 ). C. Müll. Synops. i. p. 94 (1849). Wils. Bry. Brit. p. 23 , t. 4 (1855). Harta. Skand. Fl. ed. 6, p. 435 (1854). Sull. Mosses of Un. St. p. 12, n. 9 (1856). Schinip. Torfm. p. 63, t. 22 (1858). Synops. p. 677 (r86o), et ed. 2, p. 835(1876). LiNDB. in Öfv. K. Vet. Ak. Förh. xix. p. I 39, n. 7 (1862). BERKEL. Handb. Br. Mosses, p. 308 , t. 2, f. 4 (1863). Russ. Torfm. p. 62 (1865). Schlieph. in Verh. Z. B. Gesel. Wien, 1865 , p. 400. KLINGG. in Schr. der K. Phys. CEk. Gesel. zu Königs. I872, p. 7. MiLDE, Bryol. Siles. p. 387 (1869). Hoвk. Synops. p. 26 (1873). Braithw. Sphag. Brit. Exsic. n. 26 (1877).

Sph. Aconiense, DE Not. Mss.

Sph. patulum, MitTen, Mss.

Sph. oblongum, P. Beauv. Prodr. p. r5. Brid. Bryol. Univ. i. p. 6.

Sph. crassisetum, BrIDEL, Mantis. Musc. p. 2, et Sp. Musc. i. p. I5.

Monoicous, or sometimes dioicous; in loose, deep glaucousgreen tufts. Stems robust, decumbent at base, 6-I 5 in. high, generally dichotomous, rigid, reddish brown; cuticular cells small, non-porose, in two strata; the peripheral cells incrassate, rufous brown. Stem leaves large, lingulate, very narrowly bordered, minutely auricled at base; apex rounded, slightly fimbriate; hyaline cells elongated, hexagono-rhomboid below, rhombic above, without fibres or pores, but here and there with a transverse partition.

Ramuli $4-5$ in a fascicle, of which $2-3$ are divergent, tumid, attenuated toward the points, with the leaves on the lower two- 
thirds squarrose and recurved from the middle, those of the upper third imbricated and elongated; the other branches pendent and appressed to stem, slender, terete, with all the leaves imbricated; cuticular cells elongated, the retort cells perforated but scarcely prominent at apex. Branch leaves from a very concave base, broadly ovate, suddenly becoming lanceolate above; the margin involute in the upper third, the apex minutely $3-4$ toothed, bordered by $2-3$ rows of very narrow cells; hyaline cells with numerous annular fibres and two rows of large pores; chlorophyllose cells compressed, entirely enclosed by the hyaline, but coming close to both surfaces in the lower part of leaf.

Fruit placed in the coma or in the upper fascicles, moderately elevated; bracts somewhat distant, concave-convolute, the lower oblongo-elliptic, the upper very broad, obovate, emarginate and slightly fimbriate at apex, laxly areolate, without fibres or pores. Spores yellow. Male amentula terete, clavate, yellowish green; the bracts slightly squarrose, oblong-lanceolate, the basal cells without fibres and pores, the upper shorter, with annular fibres and small pores.

$\mathrm{HAB}_{\mathrm{A}}$ - A A bout boggy springs and the shady sides of moorland streams and in woods. Fr. August.

Not uncommon throughout Europe and the middle and northern states of North America.

This fine species varies much in size and robustness, but in its ordinary state is readily known by its strongly squarrose branch leaves. The stem leaves also have scarcely any border, and their hyaline cells are almost uniform throughout the whole extent of the leaf.

Var. $\beta$. squarrosulum (LESQ.), Schimp.

Plants small, slender, in large soft tufts, deep green above, whitish below. Leaves resembling those of the type, but only half the size.

Synon.-Sph. squarrosulum, Lesquereux, Mss. KlingGr. in Schr. der K. Phys. CEk. Gesel. zu Königs. 1872, p. 8.

Sph. squarrosum $\beta$. squarrosulum, Schimp. Torfm. p. 71 ; Synops. p. 677. MiLDE, Bryol. Siles. p. 388. Russow, Torfm. p. 64. Braithw. Sphag. Brit. Exsic. n. 27.

$\mathrm{H}_{\mathrm{AB}}$. - In ditches on subalpine heaths, and at edges of bogs. Not common.

Europe.-Marais des Ponts, Swiss Jura (Lesquereux). Sweden and Finland (Lindberg). In the Riesengebirge, Prussia, Brandenburg, Mecklenburg, and Baden (Milde). England: Darnholm, Goathland, Yorkshire (Braithwaite). Scotland: Scotstown Moor, Old Machar, Aberdeen (Sim). 
This form is regarded by Lindberg as a young or imperfectly developed state of Sph. squarrosum, and has never been found in fruit. It is generally of a more dingy green colour.

Var. $\gamma$. imbricatum, Schimp.

Plants robust. Branch leaves imbricated throughout their length, or with the apex only recurved.

Synon.-Schimp. Synops. ed. 2, p. 836 (1876).

HAB.-Near Gefle, Sweden (C. Hartman).

This variety I only know by the brief description given in Schimper's Synopsis.

Var. $\delta$. laxum, BRAITHW.

Plants loosely tufted, pale whitish green, soft, 6-10 in. high. Stems slender, fragile; the leaves short, broad, quadrate, laxly areolate, deeply fimbriate at the truncate apex; the sides with a border of narrow cells, which is widest at base. Branches in distant fascicles, dependent, very long, attenuated; the leaves laxly incumbent, divergent, not squarrose, or only slightly recurved at points, broadly ovate, acute. (1877).

Synon.-Sph. fimbriatum var. robustum, BraIthw. Sphag. Brit. Exsic. n. 44

HАB.-In ditches in the old alum works at Eskdale, near Whitby, Yorkshire (Anderson).

This form is very peculiar, from its soft texture, straight leaves, and long pendent branches, which with the broad fimbriate stem leaves appear to connect it directly with $S p h$. fimbriatum.

The plants are generally stained of an ochraceous or rusty colour in the lower part, by the iron set free from the roasted alum rock.

Var. $\epsilon$. subteres, LindB.

Plants very slender, elongated, 5-10 in. high, bright green. Branches elongated, slender; the leaves imbricated, with the upper half recurved and attenuated toward apex.

Synon.-Braithw. Sphag. Brit. Exsic. n. 28.

HAB.-Subalpine bogs. Not common.

EURoPE,-Finland (Lindberg). Skeggles, Westmoreland (Barnes); Saltersgate Moor, Yorkshire (Anderson).

A very pretty variety, having much greater resemblance to Sph. intermedium than to Sph. squarrosum, the stem leaves are, however, quite normal. 


\section{Var. ל. teres (Ångstr.), Schimp. Pl. XV.}

Dioicous; more slender, pale yellowish green or pale ferruginous. Stems slender, 5-8 in. high, pale rufous red. Ramuli attenuated, their leaves closely imbricated, recurved at points. Male inflorescence turgid, fuscescent, seated in the middle of the upper divergent branches, ending in a paler, elongated, sterile point.

Synon.-Sph. teres, Ångström, in HarTm. Skand. Fl. ed. 8, p. 4r7 (r86r). Linde. in Öfv. K. Vet. Ak. Förh. xix. p. I38, n. 6. Milde, Bryol. Siles. p. 388. Schliephacke, in Verh. Z. B. Gesel. Wien, r865, p. 399. KLINGGR. in Schr. der K. Phys. CEk. Gesel. zu Königs. 1872, p. 7. BRAITHW. in Monthl. Micr. Journ. July, $\mathrm{r} 874$, p. 12, t. 68 . Sulliv. Icon. Musc. Suppl. p. r3, t. 4 (r875). Schimp. Synops. ed. 2, p. 836 .

Sph. porosum, LindB. Mss. olim.

Sph. squarrosum var. $\gamma$. teres, Schimp. Torfm. p. 64, et Synops. ed. r, p. 677. Russow, Beitr. Torfm. p. 64. Braithw. Sphag. Brit. Exsic. n. 29, 30.

HAB.-Marshy heaths in subalpine districts. Not rare.

Europe. Lapland: At Lycksele (Ångström), and many other places. Sweden, Norway, Finland, Holland, Westphalia, Silesia, Brandenburg, Prussia. England: Knutsford Moor, Wybunbury Bog, and Newchurch Bog, Cheshire (Wilson); Staveley, Westmoreland (Stabler); Dent, Yorkshire (Barnes). Scotland: Doune, Perthshire (McKinlay); Ben Ledi (Stirton); Sidlaw Hills (Gardiner).

N. AMERICA.-Closter and Southern New Jersey (Austin).

Although in external appearance, colour, and habit, this plant looks very different from Sph. squarrosum, and is so regarded by most of the leading bryologists, it will be found on careful examination to present not a single point of structural distinction, by which they can be separated.

The plants are shorter and of denser habit, but the perichatial and stem leaves, although a little narrower, agree precisely in areolation; the branch leaves indeed are ordinarily not squarrose, but we constantly meet with stems which have the lower branches more or less squarrose-leaved, while the upper retain their normal direction, and if we examine growing tufts of the plant, it is quite common to find the central stems normal, while those at the circumference of the patch have all their branches squarrose-leaved. The dioicous inflorescence and the elongated sterile termination to the antheridial branches are the sole differential characters.

It also resembles the robust forms of Sph. acutifolinm, but has stouter and more closely imbricated branch leaves, and the stem leaves are quite distinct.

l'rofessor Lindberg has pointed out that, like squarrosum, the 
branch leaves have very minute papillx on the internal wall of the hyaline cells, where united to the chlorophyllose.

\section{I2. Sphagnum fimbriatum, WiLson.}

\section{PL. XVI.}

Monoicous; slender, pale whitish green ; cuticular cells of stem in 2-3 strata. Stem leaves large, broadly obovate-spathulate; the margin in the rounded upper half laciniate-fimbriate; border of narrow cells one-third the width of leaf at base, disappearing halfway up the leaf. Branch leaves ovato-lanceolate, the chlorophyllose cells compressed, enclosed, but nearest upper surface of leaf. Perichretial bracts obovate-oblong, obtuse, emarginate. Male amentula fusiform.

Synon.-Sph. finbriatum, WiLs. in Hook. Fl. Antarct. ii. p. 398 (r847); Bryol. Brit. p. 2 I, t. 60 (1855). Suli. Mosses of Un. St. p. I 2, n. I 2 (1856). Schimp. Torfm. p. 59, t. I5 (1858) ; Synops. p. 674 (I860), et ed. 2, p. 829 (1876). LINDB. in Öfv. K. Vet. Ak. Förh. xix.p. I 37, n. 4 (1862). HARTM. Skand. Flora. Berkel. Handb. Br. Moss. p. 307 ( 1863 ). Russow, Beitr. Torfm. p. 5 I (I865). Schlieph. in Verh. Z. B. Gesel. Wien, I865, p. 391. KlingG. in Schr. der K. Phys. Ek. Gesel. zu Königs. I872, p. 4. Milde, Bryol. Siles. p. 386 (1869). Hовк. Synops. Br. Moss. p. 24 (I873). Braithw. Sphag. Brit. Exsic. n. 43 (1877).

Sph. acutifolium, p. p. Hook. Tayl. C. Müll. \&c.

Sph. capillifolium, Dozy, MoLk. Fl. Batav. p. 78 (1851).

Monoicous; in loose, pale whitish-green or glaucous-green tufts. Stem very slender, 6-14 in. long, pale green, with 2-3 layers of rectangular, porose, cuticular cells, those of the peripheral layers not coloured. Stem leaves large, erect, broadly obovate or obovatospathulate, the margin in the rounded upper half laciniate-fimbriate; hyaline cells of the middle and upper part rhombic, with one or more partitions, and without fibres or pores; chlorophyllose cells long, linear, forming a border which occupies one-third the width of base, but rapidly narrows and disappears half-way up the margin.

Ramuli $3^{-4}$ in a fascicle, very long, attenuated, two arcuate, decurved, the others pendulous, filiform. Lower ramuline leaves broadly ovato-lanceolate, upper elongate, lanceolate, acute, with a narrow border; hyaline cells with annular and spiral fibres, and a row of large pores on each side; chlorophyllose cells compressed, enclosed by the hyaline, but nearest the upper surface of leaf.

Capsules at first immersed in the large imbricated perichretium, afterwards becoming moderately exserted; lower bracts obovate- 
oblong, upper very broad, convolute, cucullate when young, obtuse or emarginate or with a small central apiculus, rather laxly areolate, without fibres or pores. Spores ferruginous.

Male amentula elongated, fusiform, yellowish green; the bracts ovate, acute.

HAB.-Bogs and marshy hollows. Fr. June and July.

EUROPE.-Not uncommon in the north. Scandinavia, Silesia, Prussia, Thuringia, Brandenburg, Holland, Belgium. England : Frequent in Lancashire and Yorkshire. Scotland: Sporadically as far north as Shetland.

N. AMERICA. - Not common.

This species is readily distinguished by its pale green colour, and large obovate stem leaves, laxly areolate and fringed all round the upper half. It does not appear to be subject to much variation, except in the length of the stem or depth of colour, which is never tinged with purple.

\section{Sphagnum strictum, LiNdBerG.}

PL. XVII.

Dioicous; yellowish green. Cuticular cells of stem in 3-4 strata. Stem leaves lingulate-spathulate, truncate and laciniatefimbriate at apex, but not below the rounded apical angles; broadly bordered with narrow cells. Branch leaves ovato-lanceolate, the chlorophyllose cells trigonous, nearest the upper surface of leaf. Perichætial bracts obovate-oblong, pointed. Male amentula elongated, clavate.

Synon.-Sph. strictum, LindB. Mss. et in Öfv. K. Vet. Ak. Förh. xix. p. 138 (1862), (ut forma Sph. fimbriati). Hartm. Skand. Fl. ed. Io (1871). Braituw. in Monthl. Micr. Journ. June, 1874, p. 256, t. 66, et Sphag. Brit. Exsic. n. 42 (1877).

Sph. Girgensohnii, Russow, Beitr. Torf. p. 46 (1 865). MuLde, Bry. Siles. p. 387 (1869). KuingG. in Schr. der K. Phys. CEk. Gesel. zu Königs. 1872, p. 3. Suluiv. Icon. Musc. Suppl. t. 5, p. 14 (1875). Schimp. Synops. ed. 2, p. 827 (1876).

Sph. fimbriatum var. majus, Aucr.

Dioicous; resembling Sph. fimbriatum, but more robust, yellowish or pale brownish green, in lax tufts. Stem straight, pale, 6-1o in. high, with 3-4 layers of porose cuticular cells, those of the peripheral layers pale green. Stem leaves erect, appressed to stem, ligulate-spathulate, truncate and laciniate-fimbriate at apex, but not below the rounded apical angles; hyaline cells of upper part rhombic, of middle base rhomboidal, free from fibres and pores, lateral of base very narrow, and with the chlorophyllose cells forming a very broad border extending up to apex. 
Ramuli $3-4$ in a fascicle, of which $2-3$ are arcuato-divergent, flagelliform, the others deflexed, filiform, appressed to stem ; retort cells elongated, perforated, scarcely recurved. Ramuline leaves erecto-patent, ovato-lanceolate and lanceolate, bidentate and sometimes recurved at apex; hyaline cells with annular and spiral fibres and numerous large pores; chlorophyllose cells trigono-compressed, nearest the upper surface of leaf.

Capsules in the capitulum or upper fascicles, bracts pale green, the lower ovato-acuminate, upper obovate-oblong, convolute, obtusely pointed, rather densely areolate, without fibres or pores.

Male plants resembling the female, amentula numerous, elongated, thickish, clavate, ochraceous or brown, the antheridia confined to the terminal portion; bracts broadly ovate, acuminate.

HAB.-Shallow bogs on subalpine heaths. Fr. July.

EURoPE.-Scandinavia and North Germany, frequent; Black Forest, Thuringia, Styria, and the Alps; Weissenburg, in the Jura, and near Eichstätt ; Bohemia, at Iserwiese and Elbwiese (Milde). Scotland: Ben Ledi (Dr. Stirton), Ben Lawers, Killin, Stroneuch Rocks in Glen Lyon, Banchory, and Clova (Hunt), near Loch Maree (Boswell). England: Skegglesmere and Dent, Yorkshire (Barnes).

N. America.-Northern New Jersey to Canada.

This species stands intermediate between Sph. acutifolium and Sph. fimbriatum, and has, no doubt, been mistaken for both; it is a stouter plant than Sph. fimbriatum, with shorter and thicker branches, and the male plant is conspicuous by its clavate inflorescence; the form of the stem leaf is, however, the distinctive character by which they may always be separated; this is truncate and fringed only at the apex in Sph. strictum, but in Sph. fimbriatum it is rounded and the fringe runs half-way down the lateral margin.

From Sph. acutifolinm in its ordinary state it is also readily known by never having the slightest tinge of red, but a form of that species occurs with the apex of the stem leaves more or less lacerate-toothed; here the numerous purple male amentula which are generally present suffice to indicate its true place; it was, however, issued in the Sphag. Brit. Exsic. as Sph. strictum, under $42 b$, and appears worthy to rank as a separate variety, which may be named subfimbriatum.

The fruit is very rare, and for the specimens figured I am indebted to the kindness of my friend Professor Lindberg; Russow states that he has it richly fruiting from Isl. Sagchalin, in Japan. 
Var. $\beta$. squarrosulum, Russow.

Plants very small, branch leaves recurved at apex; branches shorter, scarcely curved.

Synon.-Sph. Girgensohnii var. squarrosulum, Russow, Torfm. p. 47. Schimp. Synop. ed. 2, p. 828.

HAB.-Wet grassy places, at Appelsee and Ziegelskoppel, near Dorpat.

\section{I4. Sphagnum acutifolium, Ehrhart.}

\section{PL. XVIII.-XXI.}

Monoicous or dioicous; pale green, usually tinged with purple. Cuticular cells in 3-4 strata. Stem leaves ovate, acute, 5-toothed at apex, broadly bordered with narrow cells. Branches $3-5$ in a fascicle, their leaves ovato-lanceolate, toothed at the slightly truncate apex, margin involute in the upper third; chlorophyllose cells obtusely trigonous, placed between the hyaline at concave surface of leaf.

Synon.-Miuscus erectus palustris albus, foliis capillaceis, Doody, RAy, Syn. ed. 2, app. $33^{8}$ (1696).

Sphagnum canlifernm et ramosum palustre molle candicans, reflexis ramulis, foliolis angustioribus, Dill. Cat. Giss. 229 ( 17 I9), et in RAY, Syn. ed. 3, p. 104, 2 (1 724 ).

Spl. palustre, molle deflexum, squamis capillaceis, DiLL. Hist. Musc. p. 243, t. 32, f. 2 A (I 74I), et Herbar. n. 2, two spec. on left hand.

Sph. palustre, B. L. Sp. PI. p. ${ }_{5}^{69}$ (1 753). Huds. FI. Angl. p. 465 ( I 762 ). Hedw. Fund. Musc. i. t. 3, f. I3-15 (I78I). Roth, Wither. Weiss, Hull, \&c.

Sph. acutifolitum, Ehri. Pl. Crypt. Exsic.n. 72 (I 786). Schrad. Spic. Fl. Germ. p. $5^{8}$ (1794). Schultz, Fl. Starg. p. 275 (1806). Web. Mohr, Bot. Tasch. p. 73 (1807). Schkuhr, Deutschl. Moose, p. 15, t. 6 (1810). Schwargr. Suppl. I. pt. I, p. I5, t. 5 (I8I I). Rörling, Deutschl. Fl. iii. p. 36 (I 8 I 3 ). Fl. Danica, t. I 53 I (18I6). Hook. Tayl. Musc. Brit. p. 4, t. 4 (I8I8). Funck, Taschenh. p. 5, t. 3 (1821). Gray, Nat. Arr. Brit. Plants, i. p. 710, 3 (1821). Zenk. Dietr. Musc. Thuring. fasc. I, n. 20 (182 r). Nees, Hsch. ST. Bryol. Germ. i. p. I 9, t. 3, f. 8, et $8^{* *}\left(\mathrm{r}_{23}\right.$ ). Hüben. Musc. Germ. p. 28 (1833). DE Not. Syll. Musc. Ital. p. 297 (1838). C..Múli. Synops. i. p. 96 (I849). Dozy, Molkenb. Prodr. Fl. Batav. p. 78 (1851). Wirs. Bryol. Brit. p. 20, t. 4 (1855). Sull. Mosses of Un. St. p. I2, n. I I (1856). Hartm. Skand. Fl. Schinp. Torfm. p. 56, t. I3 (I858); Synops. p. 672 (1860), et ed. 2, p. 825 (1876). Lindb. in "Ofv. K. Vet. Ak. Förh. xix. p. r 38 , n. 5 (1862). Berkel. Handb. Br. Moss. p. 307 , t. 2, f. 4 (1863). Russow, Torfm. p. 37 (1865). Schlieph. in Verh. Z. B. Gesel. Wien, 1865, p. 389. KLIngGr. in Schr. der K. Phys. OEk. Gesel. zu Königs. 1872, p. 2. Mil.DE, Bryol. Siles. p. 381 (1869). Hobk. Syn. Br. Mos. p. 24 (1873). Braithw. Sphag. Brit. Exsic. n. 31 et 426 (1877).

Sph. capillifolium, Eirri. Hann. Mag. I780, p. 35. Schrank, Baiersch. Fl, ii. p. 434 (I 789). M๔ench, Pl. Marburg, p. 727 (I794). SwTz. Act. Holm. 1795, p. 28r. BRID. Musc. Rec. ii. pt. I, p. 24 (I798); Sp. Musc. i. p. I6 (I806); Mantissa, p. I (r8rg); Bryol. Univ. i. p. II (1826). Hedw. Sp. Musc. p. 28 (I80I). 
Smith, Fl. Brit. p. I 46 (1804); Eng. Bot. t. 1406 (I8I5). Turner, Musc. Hib. P. 6 (1804). P. Beauv. Prodr. p. 87 (1805). Lamarck et Cand. Fl. Franc. i. p. 445 ( 1805$)$.

Sph. capillaccum, Swartz, Musc. Suec. p. I8 (r798). Wahlenb. Fl. Lapp. p. 302 (181 2), et Fl. Carpat. p. 333 (1814).

Sph. pentastichum, Brid. Sp. Musc. i. p. 16 (1806); Mant. Musc. p. 2 (I819).

Sph. capillifolioides, BreUtel, Bot. Zeit. I824, p. 438 . Brid. Bry. Univ. i. p. 75 I. Sph. ascherbachianum, BREuteL, 1. c. p. 439.

Sph. subulatum, Brid. Sp. Musc. i. p. 19; Mant. Musc. p. 3, et Bry. Univ. i. p. I8. Schwägr. Suppl. I. pt. I, p. I8.

Monoicous or sometimes dioicous; in soft tufts, pale green, usually more or less tinged with purple. Stems slender, dichotomous, pale; cuticular cells generally without pores, in 3-4 strata; cells of the peripheral layers incrassate, purple. Stem leaves erect, ovato-acuminate, concave, with the margin incurved, minutely auricled at base, 5-toothed at apex; hyaline cells of the middle base hexagono-rhomboid, with one or two oblique partitions, without fibres or pores, the upper also divided, and often slightly fibrillose, lateral very narrow and forming a broad border, gradually decreasing in width toward apex.

Ramuli $3-5$ in a fascicle, $2-3$ arcuato-divergent, $I-2$ pendent, filiform, all more or less attenuated at points; their retort cells flask-shaped, subcylindric, perforated and slightly recurved at apex.

Ramuline leaves minute and ovate at base, median ovatolanceolate, erecto-patent, deeply concave, uppermost narrowly lanceolate, all toothed at the slightly truncate apex, and with the margin involute in the upper third; hyaline cells confluent at back, with a few large pores and annular fibres, those of the upper half of leaf much smaller, more densely fibrose, and with smaller pores; border extremely narrow, of two rows of long thin cells; chlorophyllose cells obtusely trigonous, interposed between the hyaline at the concave surface of leaf.

Capsules numerous, usually clustered in the capitulum; peduncle moderately elongated, the bracts numerous; straw-coloured or reddish, lowest broadly ovate, acuminate, concave, median oblong, narrowed at apex, uppermost elongated, convolute; the hyaline cells narrower and more solid than in the cauline leaves, with 2-3 partitions, but no fibres or pores. Spores ferruginous. Male inflorescence purple, in clavate acute amentula ; the bracts in five rows, ovate, acute.

HAB.-Heaths and bogs, forming loose cushions. Common throughout Europe and North America. Fr. July. 
The typical state of Sph. acutifolizum is that termed robustum by Blandow and Nees and Hornschuch, in which the stems are stout and often tall, the branches rather short, thick, and glossy, with leaves more or less tinted with red. So much, however, does the plant vary in size, colour, and density, and in the form of both the stem leaves and branch leaves, that an endless series of forms result, the transitions between which are so gradual that it becomes difficult to keep the varieties within definite bounds. Schliephacke pointed out an important character in the structure of the branch leaves, viz. that the divergent branches bear up to the middle, leaves whose lower wider cells have single large pores, these cells becoming towards the point very small, closely and equally smallpored; but as the leaves rise higher on the branches, they gradually pass to a lanceolate or lanceolate-subulate form, and the areolation then becomes uniform throughout the leaf, wider, laxer, and provided with equal large pores.

The apex of the stem leaves in the robust form is often somewhat truncate and slightly fringed, and thus may be easily mistaken for Sph. strictum, as was the case in my Exsiccata, under n. $42 b$ (var. subfimbriatum); but Sph. acutifolium may be known from that species by its red amentula, and softer, laxer branch leaves; in other forms the point is obtusely rounded, with small imperfect teeth, or again the teeth may be distinct and well defined.

The stem leaves also vary considerably in form and size; occasionally we find them very long and ligulate-lanceolate in outline, or they may pass to the opposite extreme and be short and broadly ovate, but unfortunately these differences are not always associated with the same conditions of habit and colour, and thus a sharply defined limit to the numerous varieties of this species appears to be impossible.

Var. $\beta$. deflexum, Schimp.

Plants densely tufted, short, with closely placed fascicles. Branches long, flagelliform, all deflexed, their leaves closely imbricated, longer and narrower, pale green and red. Stem leaves ovate, pointed, mostly fibrillose. Branch leaves lanceolate, acuminate.

Synon.-Sph. acutifolium var. $\beta$. deflexum, Scн1мp. Torfm. p. 57, t. xiii. $\beta$; Synops. p. 673 , et ed. 2, p. 826 . Russow, Beitr. p. 39 (including also his var. laxum). MrLde, Bry. Siles. p. 381. Klingar. in Schr. der K. Phys. CEk. Gesel. zu Königs. 1872, p. 3. BRaithw. Sphag. Brit. Exsic. n. 32. 

tricts.

HAB.-Margins of bogs and about the edges of woods, chiefly in alpine dis-

Lapland, Alps of Switzerland, Dovrefjeld. Scotland: Gelan Bog and Dalfroo Bog, Strachan, Kincardine (Sim); Garynahine, Isl. Lewis, Hebrides (Braithwaite). England: Darnholm, Goathland, Yorkshire (Anderson).

This variety stands nearest the typical form, into which it passes imperceptibly; the branches are generally rosy red, with pale points, or a mixture of green and red, and the texture softer. Russow's var. $\gamma$. laxum appears to be only a tall, loose-leaved form of the same variety, and Spruce's lilacinum is intermediate between this and the next.

\section{Var. $\gamma$. purpureum, Schimp.}

In dense cushioned tufts, almost entirely purple, short, densely ramulose, the capitulum dense. Stem leaves ovate, usually fibrose, sometimes slightly truncate, and fringed at point. Branch leaves ovato-lanceolate, closely imbricated.

Synon.-Sph. acutifolium var. purpureum, Schimp. Torfm. p. 57 , t. xiii. $\delta$; Synops. p. 673, ed. 2, p. 826. Russow, Beitr. p. 40. Milde, Bry. Siles. p. 38 I. KLINGG. in Schr. der K. Phys. CEk. Gesel. zu Königs. 1872, p. 3. Braithw. Sphag. Brit. Exsic. n. 33.

HAB.-Marshes and moorlands; not unfrequent in mountain districts.

This comes close to the last variety, but has shorter and more spreading branches, with shorter branch leaves; the colour is also a deeper purple, but pale at the lower part of the stems.

\section{Var. $\delta$. rubellum (WiLs.), Russow.}

Dioicous; plants slender, laxly tufted, purple, $2-6$ in. high. Stem leaves large and broad, obtuse, their cells bipartite, but rarely fibrose. Branch leaves subsecund, oblong-ovate, rather obtuse, 3 -toothed at apex. Male amentula deep purple, clavate, obtuse.

Svnon.-Sph. rubellum, Wils. Bryol. Brit. p. I9, t. lx." (I855). Schimp. Torfm. p. 70, t. xx. ; Synops. p. 680, et ed. 2, p. 826. LindB. in Öf. K. Vet. Ak. Förh. xix. p. I 42, n. 12. Berkel. Handb. p. 306. Hartm. Sk. Fl. ed. 9, ii. p. 83 (1864). Fl. Danica, t. 2753 (I867). Milde, Bry. Siles. p. 383. Schlieph. in Verl. Z. B. Gesel. Wien, 1865 , p. 388 . Braithw. in Monthl. Micr. Journ. July, 1872, pl. xxii. Новк. Synop. Br. Moss. p. 24.

Sph. acutifolium var. rubellum, Russ. Torfm. p. 4I. BraIthw. Sphag. Brit. Exsic. n. 36 .

Sph. tenellum var. $\beta$. rubellum, KLINGGR. in Schr. der K. Phys. CEk. Gesel. zu Königs. 1872 , p. 4 .

HAB. - In marshes at the edges of small pools; rare in fruit. Often growing intèrmixed with Sph. tenellum.

Europe.-In Sweden, Norway, Finland, and Denmark; not unfrequent. Bavaria, 
Silesia, Thuringia, Prussia, Salzburg, Holland. England: Frequent in Lancashire, Yorkshire, and Westmoreland; found also in other counties and in Scotland and Ireland.

N. AMERICA.-Has been found occasionally.

After the examination of many specimens from Wilson himself, and from all parts of the kingdom, I feel compelled reluctantly to follow Russow in reducing Sph. rubellum to one of the long chain of varieties which constitute the polymorphous Sph. acutifolizm.

We may briefly consider the various points of distinction referred to by Wilson and Schimper.

1. The small size and delicacy of the plants.-This condition is only relative, as specimens of rubellum 6 inches high are not unfrequent, while other varieties of acutifolium are found of even smaller size than ordinary rubellum.

2. The dioicous inflorescence.-This is the strongest point for the specific character of Sph. mbellum, but other varieties of acutifolium are also dioicous, nay, I believe at times its typical form is so.

3. The larger non-fibrose stem leaves.-A reference to the plates will suffice to show that stem leaves of mbellum are not larger than those of typical acutifolium; and again in rubellum, threads are frequently present, and sometimes they are quite wanting in the cells of the stem leaves of acutifolinm.

4. The broader elliptical branch leaves.-The lowest leaves of the divergent branches are very broad and obtuse, and those from the middle moderately so; in no case have I seen them truly elliptical, and often on the same plant others will be found moderately pointed, while other varieties, e.g. temue, arctum, fuscum, \&c., have them quite as obtuse, neither is their subsecund direction constant.

Sufficient, I think, has therefore been advanced to show that Sph. rubellum possesses no character of sufficient weight to entitle it to specific distinction; the upper branches are usually twisted, but this is by no means constant, and occasionally we find specimens with very little admixture of red, being either dull green or a pale brown with only the comal branches purple, and for this form I have used the name ambigumm. 
Var. є. tenue, Braithw.

Stems elongated, slender, laxly tufted; the branches arcuate, decurved, very slender, rather short.

Stem leaves very broadly bordered, large, ovate, truncate, lacerate at rounded apex, rarely fibrose.

Branch leaves small, short; green, and purple, less densely imbricated, ovate with a rounded point. Plants dioicous.

Synon.-Sph. acutifolium var. $\gamma$. tenellum, Schimp. Torfm. p. 57 , t. xiii. $\gamma$; Synops. p. 673, et ed. 2, p. 826. Russow, Beitr. Torfm. p. 44. MirDE, Bry. Siles. p. $38 \mathrm{r}$.

Sph. tenellum, KLINGGR. in Schr. der K. Phys. CEk. Gesel. zu Königs. 1872, p. 4 .

Sph. acutifolium var. tenue, BRAITHw. Sphag. Brit. Exsic. n. 37 .

HAB.-In deep bogs in mountain districts.

EURore.-Silesia, Bunzlau (Limpricht); Hochwald, near Waldenburg (Zimmerman) ; Lapland, Lycksele (Ångström); Prussia (Klinggräff). Westmoreland, Skeggles (Barnes); Yorkshire, Bleaberry Gill, Goathland (Anderson).

In form of leaf this comes very close to rubellum, and would have to be transferred to it, if that is to continue a species.

Var. $\zeta$. quinquefarizm, LiNDB.

Plants slender, 4-6 in. high, with a hemispherical dense capitulum; pale green above, pale yellowish green below, more or less intermixed with light purple.

Stem leaves with a broad base, deltoid, obtusely pointed, and with five teeth at apex; the cells without fibres.

Divergent branches spreading, flexuose; the leaves when dry distinctly 5-ranked, divergent or somewhat recurved, small, obtuse, 5 -toothed.

Synon.-Bratthw. Sphag. Brit. Exsic. n. $37 b$ (sub var. temue).

HAB.-Subalpine bogs in woods.

Europe.-Finland (Lindberg). Ireland: In a damp pine-wood at Glenfarne, Leitrim (Dr. Moore, May, 1875 ).

This beautiful plant stands near to var. temue, but is much more robust and of softer texture, and is beautifully variegated with pale yellow-green and rose colour; the most distinctive character, however, is that of the 5-ranked, widely divergent leaves, most conspicuous in the dry state, which are also larger and more acuminate.

Var. $\eta$. gracile, Russow.

Stems slender, firm and rigid, 4-6 in. high, pale red and green above, reddish brown below. Stem leaves obtuse, 5-toothed, 
faintly fibrillose in the upper part. Fascicles distant above, closer below, the branches spreading, arcuato-decurved, unequal in length, some being attenuated at point, others not; the leaves short, obtuse, toothed, their hyaline cells very small in the upper half, with very small pores bordered by stout rings.

Synon.-Russow, Beitr. Torfm. p. 44.

$\mathrm{H}_{\mathrm{AB}}$ - Bogs at borders of moorlands. Frequent about Dorpat (Russow). Kardis (Bruttan).

In some respects this approaches to the var. rubellum, with which it quite agrees in the form and structure of the stem leaf; the branch leaves differ in structure, though similar in form, and the habit is altogether more lax.

Var. $\theta$. elegans, Braithw.

Stems slender, dichotomous, 4-8 in. high, fastigiate, in very densely cushioned tufts, rosy purple above, dirty white below. Stem leaves very long, oblong, suddenly contracted at apex into an obtuse 5-toothed point, fibrillose in the upper half, with a few pores.

Branches in densely placed fascicles, and forming a small, dense, hemispherical capitulum; divergent ones short, slender, often white at points, arcuato-decurved; the leaves small, closely imbricated, rather obtuse, 5-toothed.

Synon.-Braithw. Sphag. Brit. Exsic. n. 35 .

$\mathrm{HAB}_{\mathrm{A}}$-Elevated peat-moors.

Scotland: Ross-shire, at edge of ravines on Little Wyvis, Strath Garve, and moors near Loch Achilty (Braithwaite, July, 1876); Hebrides, Isl. of Lewis, intermixed with S. Austini, B. (forma nanum).

This beautiful peat-moss must, I think, have been confounded with some of the other red forms, as it is plentiful in the localities noted. The Hebridean plant does not exceed 2 inches in height, and has the branches ascending, but structurally agrees with the larger form.

Var. ı. fuscum, Scirmp.

In very dense, fastigiate, cushioned tufts, cinnamon brown above, fuscous below. Stems very long and slender, the cells of the peripheral layers dark brown, densely and uniformly ramulose; ramuli short, pale at apex, the pendent ones often whitish. Stem leaves without fibres, ovate, truncate and lacerate at point. Branch 
leaves ovate, narrowed at middle, and ending in a rounded toothed point.

SYnon.-Sph. acutifolium var, є. fuscum, Schimp. Torf. p. 57, t. xiii. $€$; Synops. p. 673, et ed. 2, p. 826. Russow, Beitr. p. 40. Milde, Bry. Siles. p. 382. BRaIthw. Sphag. Brit. Exsic. n. 39 .

Sph. fuscum, KurngGrärf, in Schr. der K. Phys. CEk. Gesel. zu Königs. 1872, p. 4 .

$\mathrm{H}_{\mathrm{AB}}$ - - On extensive moors, forming vast and dense sods.

Europe.--Silesia, Prussia, Thuringia, Lapland ; about Dorpat, abundant (Russow). England: Witherslack Moss, Westmoreland (Barnes). Scottand: Morvan, Kincardine, at 2500 feet (Sim).

Plainly coloured as this variety is, nothing can exceed the beauty of a great bed of it, when freshly moistened by a shower, resembling, as it does, a surface of snuff-coloured velvet, and it is almost with regret that we cannot follow Klinggräff in elevating it to the rank of a species; histologically, however, it does not present any distinctive characters.

Var. $\kappa$. arctum, BRAITHw.

Plants in very densely cushioned tufts, 2-3 in. high, pale yellow green above, brownish white below. Stem leaves ovate, auricled, obtuse; the margin involute at apex, which has five obtuse teeth; cells of the upper half fibrillose. Branches in very close fascicles, short, ascending, arcuate below ; the leaves obtuse, 5 -toothed.

Synon.-Sph. acutifolium var. arctum, Brarthw. in Monthl. Micr. Journ. April, I874, p. 157 .

Spl. molle var. archum, Brarthw. Sphag. Brit. Exsic. n. $2 \mathrm{r}^{*} a$ et $b$.

$\mathrm{HAB}_{\mathrm{A}}-$ On extensive peat-moors in the north. Ireland: Connemara, Galway (Dr. Moore). England: Witherslack Moss, Westmoreland (Barnes). Scotland : Shetland Islands, Unst, and Reawick (Sim).

This is the compact variety of the species, and has a very peculiar aspect from its dwarf size and dense tufts, which form close cushions. A faint tinge of purple may generally be observed on some of the branches.

\section{Var. $\lambda$. luridum, HUEBEN.}

Plants 4-5 in. high, in dense tufts of a dull green colour above, fuscous below. Branches densely crowded, erecto-patent, of equal length, their leaves closely imbricated, acuminate, strongly involute at points. Stem leaves large, elongated, linear-oblong, 
attenuated suddenly into a narrow minutely-toothed point, free from fibres.

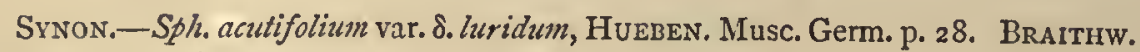
Sphag. Brit. Exsic. n. 40.

HAB.-Deep peat-bogs.

EURoPE. - Barmbeck, near Hamburg (Huebener). Ben Lawers, Perthshire (Braithwaite); Darnholm, Goathland, Yorkshire (Rev. Mr. Crouch); Witherslack Moss (Barnes); near L Llanberis (Boswell).

I have referred this plant to Huebener's variety, as it closely accords with his description. The plants have a dirty brownish tinge, and their closely placed fascicles with the branches of equal length give it rather a peculiar appearance, not usual in any forms of Sph. acutifolium.

Var. $\mu$. late-virens, BRAithw.

Growing in small dense tufts, bright green above, light or ochraceous brown below. Stem leaves ovate, short, or elongated; the apex obtuse, obscurely 5 -toothed; the cells without fibres. Branches in rather remote fascicles, elongated, ascending and divergent; the leaves loosely imbricated, large, broadly ovate at base, suddenly narrowed into a longish, truncate, 5 -toothed point.

$\mathrm{H}_{\mathrm{AB}}$. - By the margin of moorland streams.

At Darnholm and Kazebeck, Goathland, Yorkshire (Braithwaite). Reawick, Shetland (Sim).

This may possibly be a form of the next variety, but as I have no authentic types of the latter it may for the present stand apart. The small dense cushions, of a beautiful bright green colour while growing, are very unusual in this species, from which some shade of red is hardly ever absent. At Darnholm it grows with Sph. molle, $\beta$, and thus got accidentally introduced into the Splag. Brit. Exsic. with that plant; at Kazebeck it is found intermixed with Sph. cymbifolium var. congestum.

Var. $\nu$. patulum, Scrimp.

Plants more robust, pale green. Branches lax, elongated, flexuose, spreading; their leaves longer, patent, laxly incumbent, broadly ovate, loosely areolate. Stem leaves large, the apex obtuse, lacerate, or fimbriate.

Synon.-Sph. acutifolium var.. patulum, Schimp. Synops. p. 674, et ed. z, p. 826. Brairitw. Sphag. Brit. Exsic. n. 41. 
HAB.-Among grass, by the shady sides of streams.

England: Darnholm, Goathland, Yorkshire (Braithwaite); about Ulverston, Lancashire (Miss Hodgson); Barbon Fell, Westmoreland (Barnes); Penzance, Cornwall (Curnow).

What I assume to be this variety grows in loose tufts, having large flexuose branches, and large somewhat divergent leaves with a slight gloss.

\section{Sphagnum Wulfii, Girgensohn.}

PL. XXII.

Monoicous; robust, more or less rufescent, the stem with two layers of cuticular cells. Stem leaves small, dilated at base, lingulate, rather acute, without fibres or pores. Branches $7-12$ in a fascicle, their leaves ovato-lanceolate, erecto-patent, with three minute teeth; chlorophyllose cells central, oval or rectangular in section.

Synon.-Spl. Wulfanum, GiRgens. Archiv für Naturkunde Liv-, Est- und Kurlands, ser. 2, band ii. p. 173 (1860). Bot. Zeit. 1862, p. 247. Russow, Beitr. zur Kennt. Torfm. p. 66 (1864). Milde, Bry. Siles. p. 385 (1869). Austin, Musc. Appal. n. 32 (1870). Braithw. in Monthl. Micr. Journ. Oct. 1874, p. 169, t. 77. Sulliv. Icon. Musc. Suppl. p. I8, t. 9 (1875). Schimp. Synops. ed. 2, p. $83^{8}$ (1876).

Sph. pycnociadum, ANGström, in Öfv. Vet. Ak. Förh. xxi.p. 202 (1864). RABENH. Bryoth. Eur. fsc. xv. n. 709 ( 1864 ). Schliephacke, in Verh. Z. B. Gesel. Wien, I 865, p. 392.

Monoicous; robust, yellowish or brownish green, or sometimes deep green, in loosely cohering tufts.

Stems $5^{-1} 2$ in. high, simple or sometimes divided, blackish brown, solid, densely ramulose; cells of the peripheral zone purple, in 5-6 layers, strongly incrassate; cuticular cells in two strata, small, non-porose. Stem leaves small, from a broad base, lingulatetriangular, reflexed, rather acute, eroso-subdenticulate at apex; the hyaline cells repeatedly divided, without fibres or pores, those in the middle rhomboidal, becoming narrower towards the margin, where they form a border of $3^{-6}$ rows.

Ramuli $7-12$ in a fascicle, $3-5$ divergent, short, slightly arched, becoming clavate upward and then suddenly pointed; the rest deflexed and closely appressed to stem, very long, slender and filiform, lax-leaved, often of a pale rose colour; the porose cuticular cells short and scarcely differing from the rest. Branches of the coma short, thick, and numerous, forming a large dense capitulum. 
Leaves of the divergent branches quinquefarious, imbricated, erecto-patent, recurved in their upper half, or subsquarrose, all with a border of two rows of very narrow cells; the basal minute ovato-lanceolate, the median ovate, elongato-lanceolate, with the margin involute, and 3-4 minute teeth at apex, the uppermost narrowly lanceolate, scarcely toothed. Hyaline cells with annular fibres, the upper with numerous small pores on each side of cell, lower lateral with large pores, which become fewer towards the middle of leaf. Chlorophyllose cells very slender, compressed, enclosed by the hyaline in the upper part of leaf, but coming to both surfaces in the lower part, oval or rectangular in section.

Perichætia clustered in the capitulum, straw-coloured or pink, lower bracts ovate, acuminate, concave, recurved at apex, upper elongate oblong, slightly emarginate and somewhat recurved at point, convolute, without fibres or pores, often subsecund.

Capsules but slightly exserted, small, globose, blackish brown. Spores pale yellow.

Male inflorescence purple, at the apex of subclavate branches in the coma or upper fascicles; the antheridia pale green.

$\mathrm{H}_{\mathrm{AB}}$. - Wet pine-woods; rare. Fr. July.

EUROPE.-Techelfer Woods, near Dorpat, frequent (Girgensohn, 1847); Kaddak near Reval, Allentacken, and Appelsee (Russow); Jamni-Les, near Permesküll (Gruner); Berglunda, near Lycksele, and Wilhelmina Kyrka, Lapland (J. Ångström, r864); Kajana and other places in Finland (Brotherus); Medelpad, Stöde (Seth).

N. America.-Belleville, Canada (Macoun, Fowler); near New York (Howe, Peck, Austin).

This beautiful species may be readily known by its clavate divergent branches, and the large number of them in each fascicle, as well as by the small stem leaves, and the dense globose capitulum; in all other points its affinity is clearly with Sph. acutifolium, from which, however, it is abundantly distinct. The delicate rose colour which sometimes suffuses this plant, adds very much to its elegance.

\section{Var. $\beta$. squarrosulum, Russow.}

Divergent branches longer, their leaves squarrose, with more numerous pores.

Synon.-Russow, Beitr. Torf. p. 68. Schimp. Synops. ed. 2, p. 839 .

HAB.-South Angermannland (Fristedt); birch woods near Ilmazal and Dorpat, and at Techelfer and Appelsee (Russow). 


\section{Sphagnum Lindbergii, Scrimper.}

PL. XXIII.

Monoicous; glossy yellowish green tinged with reddish brown, the stem with 3-4 layers of cuticular cells. Stem leaves auricled, broadly lingulate; the apex broadly truncate and fringed.

Branch leaves in five rows, not undulated, ovato-lanceolate, toothed at apex; the chlorophyllose cells elliptic, enclosed by the hyaline, but nearest the back of leaf. Perichætia large, inflated; bracts oblong, truncate and fimbriate at apex.

Synon.-Sph. Lindbergii, Schimp. Torfm. p. 67, t. 25 (I858); Synops. p. 679 (1860), et ed. 2, p. 832 (1876). Lindr. in Öfv. K. Vet. Ak. Förh. xix. p. 136, n. 2 (I862). Hartm. Skand. Fl. ed. 9, p. 8 I (I864). Russow, Beitr. zur Kennt. Torfm. p. 54 (1864). Schlieph. in Verh. Z. B. Gesel. Wien, i865, p. 398. Milde, Bry. Siles. p. 389 (1869). Austin, Musc. Appal. n. 40 (1870). Braithw. Sphag. Brit. Exsic. n. 45 (exot.).

Sph. cuspidatum, LiNDB. in Bot. Notiser, i856, p. I 22.

Sph. cuspidatum $\beta$. fulvum, and Sph. fulvum, SENDTNER, Mss.

Monoicous; growing in large dense tufts, glossy yellowish green, tinged with ferruginous or purplish brown.

Stems 6-1 2 in. high, solid, dark brown; the peripheral cells rufous red, not much thickened; the cuticular cells irregular in size, without pores, forming 3-4 strata. Stem leaves crowded, reflexed, broadly lingulate, auricled; the apex broad, transversely truncate and fringed; basal cells hexagonal, in four. rows, pale brown, then becoming narrow and elongated, with a few imperfect fibres in the lateral cells, these narrow cells bound a central triangle, the base of which is formed by the apical margin, and this space is occupied by large, loose, rhombic cells, broader and 2-3 partite at the apex of leaf; without fibres and pores, both of which occur sparingly in the auricles.

Ramuli $4-5$ in a fascicle, $2-3$ arcuate, divergent, the others pendent, elongated, and closely appressed to the stem ; retort cells of the branches larger, recurved at apex.

Leaves of divergent branches numerous, in five ranks, firm, not undulated, rather glossy, brownish or ferruginous green, ovate at base, becoming lanceolate above, toothed and involute at apex; hyaline cells elongated, with numerous annular and spiral fibres, and many minute pores at margin; chlorophyllose cells narrow, elliptic in section, quite enclosed but nearest to back of leaf; border widest at base, formed of $3-4$ rows of very narrow cells. 
Capsules numerous, seated in the capitulum, moderately elevated. Perichætia large, inflated; the bracts yellowish green, lower elongated oblong, upper broadly obovate-oblong, convolute, truncate and fimbriate at apex, transversely undulate at base, without fibres or pores. Spores yellow.

Male inflorescence consisting of few antheridia, which are borne on the pendent branches.

HAB.-Deep bogs in the north. Fr. July.

Europe.-Near Lakes Betsetjaur, Skatijaur, and Storavaviken, in Pitean Lapland (Lindberg, 1856 ); pretty generally distributed in other parts of Lapland, as well as in Finland and the north of Sweden; Dovrefjeld, Norway (Berggren); in the Riesengebirge, Silesia; Weisse Wiese (Sendtner, $\left.183^{8}\right)$; Kleiner Teich, Pantsche Fall; Elbwiesen; Gr. and Kl. Schneegrube (Milde); Alps of Salzburg (Sauter). Ben Wyvis, in Ross-shire, Scotland (McKinlay, 1867); north end of island of Unst, Shetland (Sim, 1878).

N. America.-Newfoundland; Canada (Drummond), and also in Greenland.

This fine species closely resembles Sph. intermedinm in appearance, but is easily distinguished by the very different stem leaves, and the non-undulated branch leaves, unaltered by drying, as well as by the glossy ferruginous tint; it is also much more robust, and by the areolation comes near the subsection acutifolia. It does not appear to be subject to any variation except in the shades of colouring; but the Scotch specimens are very small in comparison with those from Lapland.

\section{I7. Sphagnum intermedium, Horfmann.}

PL. XXIV. And XXV.

Dioicous; robust. Cuticular cells in $2-3$ strata, small, thin, and indistinct. Stem leaves ovato-triangular, without fibres or pores, broadly bordered with narrow elliptic cells. Pendent branches closely appressed to stem and concealing it. Branch leaves densely imbricated, broadly lanceolate; the margins undulate and points recurved when dry. Spores yellow.

Synon.-Sph. palustre, molle, deflexum, squamis capillaceis, Dil.. Hist. Musc. p. 243 , t. 32, f. 2 A (1741), et Herbar. fol. 32, middle specimen on the left.

Sph. intermedium, Hoffm. Deutsch. Fl. ii. p. 22 (1796); excl. syn. Dillenii et var. $\beta$. Crome, Samml. Deutsch. Laubm. fasc. 1, p. 25, n. 4 (1803). Bratthw. Sphag. Brit. Exsic. n. 47 (1877).

Sph. recurvum, P. Beauv. Prodr. p. 88 (1805). BRID. Sp. Musc. i. p. I6 (1806), et Bry. Univ. i. p. $1_{3}(1826)$. LiNDB. in Öfv. K. Vet. Ak. Förh. xix. p. I 36, n. 3 (1862). Berk. Handb. Br. Moss. p. 308 (1863). KlingGr. in Schr. der K. Phys. Ek. Gesel. zu Königs. 1872, p. 5. Новк. Syn. Br. Moss. p. 25 (1873). Sснimp. Synops. ed. 2, p. 830 (1876). 
Sph. acutifolium var. a. rccurvum, WEB. MоHR, Bot. Tasch. p. 74 (i807). SwARTZ, Adnot. Bot. p. 74 (1829).

Sph. cuspidatum a. NeES, Hscr. St. Bryol. Germ. i. p. 23, t. 4, f. 9 (I823). C. MÜll. Synops. i. p. 96 (1849), et Deutschl. Moose, p. 125 (1853). Jensen, Bry. Danica, p. 47 (1856). Sull. Mosses of Un. St. p. I3, n. I5 (1856). Schimp. Torfm. p. 60, t. 16, f. I (1858), et Synops. p. 675 (I860). Russow, Beitr. p. 55 (I865). Hartu. Skand. Fl.ed. 7, p. 399 (1858). Schliep. in Verh. Z. B. Gesel. Wien, I865, p. 393. MiLDE, Bry. Siles. p. 383 (1869), et p. p. Aucr.

Sph. cuspidatiforme, BREUTRL, Bot. Zeit. 1824, p. 407. BRID. Bry. Univ. i. p. 752.

Sph. albescens, HÖ. Deutsch. Leberm. fasc. 3, n. 73 ( 1837 ).

Sph. flexuosim, Dozy, Molk. Prodr. Fl. Batav. p. 76, t. 3 (I 851 ).

Sph. cuspidatum et var. $\beta$. recurvum, WiLs. Bry. Brit. p. 2 I (1855). ( 1854$)$.

Sph. Mougrotii, Schimp. in Moug. NestL. St. Crypt. Vog.-Rhen. fasc. ז4, n. г 306

Sph. dubium, WiLs. Mss. in Herb. suo.

Dioicous ; plants robust, straight, in large dense or lax tufts ; yellow green, pale green or sometimes pale ferruginous above, pale brown or whitish below. Stems 6-12 in. high, greenish white, fragile; cuticular cells in $2-3$ strata, small, thin, not porose, hardly distinct from the subjacent pale peripheral cells of stem. Stem leaves reflexed, rather small, ovato-triangular, minutely auricled, without fibres or pores, broadly bordered with narrow elliptic cells ; the apex somewhat obtuse with $3-5$ small teeth, not involute at margin.

Branches $4-5$ in a fascicle, two divergent and arched downward, the rest pendent, attenuated, closely appressed to the stem and concealing it ; those of the coma numerous, short, obtuse, squarroseleaved, forming a large dense capitulum; retort cells elongated, perforated, and slightly recurved at apex. Branch leaves denscly imbricated, erecto-patent, broadly lanceolate, involute toward apex which has 2-3 minute teeth, when dry rather glossy, with the margins undulate and points recurved. Border of 2-4 rows of extremely narrow elongated cells; hyaline cells of the upper half elongated, filled with annular and spiral fibres, and with a few small pores; of the lower half very long, with annular fibres only and no pores; chlorophyllose cells free on the posterior surface, trigono-compressed in section.

Capsules numerous in the capitulum, exserted, and also in the upper fascicles. Perichætium yellow green, the bracts broadly oval, pointed, concave; the hyaline cells small, without fibres or pores, lower ovate, acuminate, recurved at apex, upper elliptic oblong, emarginate. Spores yellow. 
Male amentula fusiform, subclavate, ochraceous; the bracts ovate, acuminate.

HAB.-Open moorlands, wet heaths, and spongy mountain bogs. Fr. July.

Europe and North America from the plains to the mountain region; frequent.

Professor Lindberg has satisfactorily settled the nomenclature of both Sph. cuspidatum, EHRH. and Sph. intermedium, HoFrm., from an examination of original specimens of both authors preserved at St. Petersburg; Hoffmann's description is otherwise far too brief for correct determination, and his var. $\beta$ is to be referred to $S p h$. acutifolium, EHRH.

Professor Schimper at first united his plant with the following species, as Sph. cuspidatum, EHRH., regarding the present as the type and the other as a submersed variety, and moreover described them as monoicous. The habit, texture, and general facies of the two are so dissimilar, that they may generally be distinguished without difficulty. The chief characters to be noted in Sph. intermedium are the pendent branches quite concealing the stem, the indistinct cuticular cells, the branch leaves undulated and more or less squarroso-recurved at point when dry, the broadly oblong, apiculate, more densely areolate perichætial bracts, the much shorter cells in the border of the stem leaves, and the pale yellow spores.

The plant varies greatly in height and stoutness, as well as in colour; the latter is sometimes pale green above and white below, but in the majority of cases it is yellowish green and often with more or less of a golden yellow or fulvous tint, especially in the comal branches, and in this form it may possibly be mistaken for Sph. Lindbergii, while the green state is on the other hand quite as likely to be taken for Sph. strictum.

\section{Var. ß. riparium (ÅNGSTR.), LINDB.}

Plants robust, 9-1 8 in. high, deep dull green. Capitulum large, with numerous very long drooping branches, all gradually attenuated from the middle. Stem with the cuticular cells very indistinct. Stem leaves large, elongato-triangular, the apex obtuse and toothed, or lacerate, or rounded and more or less fimbriate.

Branch leaves closely imbricate, ovato-lanccolate, recurved at apex when dry, the point elongated, consisting of flexuose chlorophyllose cells alone without any fibrillose. 
Synon.-Sph. riparium, ^̊astr. Öfv. Vet. Ak. Förh. xxi. p. 198 (r864). KLINGG. in Schr. der K. Phys. CEk. Gesel. zu Königs. 1872, p. 6.

Sph. cuspidatum var. majus et var. speciosum, Russow, Beitr. Kennt. Torfm. p. 57 (r865). MrLde, Bryol. Siles. p. 384 .

Sph. speciosum, KLIngGräFf, in Schr. der K. Phys. CEk. Gesel. zu Königs.

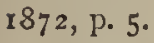

Sph. cuspidatum var. $\delta$. fallax, KLINGG. 1. c. p. 7 .

Sph. spectabile, Schrmp. Synops. ed. 2, p. 834 (1876).

Sph. obtusum, Warnstorf, in Botan. Zeit. 1877, p. 478.

Sph. intermedium var. riparium, LindB. BraIturw. Sphag. Brit. Exsic. n. 49.

HAB.-Deep moorland ditches, more or less immersed.

EURoPE.-Scandinavia: In Upland and Westrobothnia; Grycsbo, in Dalecarlia (Lindberg); Ostergothland, in Sweden (Dusen); Finland, Jurva (Simming), and Kajana (Brotherus); Snasen Vatten, in Norway (Hartman). Germany: Labiau; Iserwiese, in the Riesengebirge (Limpricht); Heiligen-Geist-See, near Arnswalde, in Neumark (Warnstorf); Stuhm and Ibenhorst, in Prussia (Klinggräff); Silesia (Milde); sparingly in Livland, Estland, and Courland (Russow). England: Woolston Moss, Cheshire (Wilson); Old Trafford Moor, Manchester (Hunt).

This fine plant has several peculiarities which almost entitle it to rank as a sub-species, notably the areolation of the point of the branch leaves, free from hyaline cells. When fully developed, it is one of the noblest of the genus, and the long drooping branches are very pretty; the stem leaves vary somewhat in their points, being occasionally deeply lacerated, at other times nearly entire. It is to be feared the Manchester locality has now been planted with bricks and mortar.

\section{Var. $\gamma$. pulchrum, LiNDB.}

Plants robust, densely tufted, with crowded fascicles, yellow green often with a golden fulvous tinge. Stem more rigid, with the cuticular cells more distinct; stem leaves acute and usually contracted suddenly at apex into a minute recurved apiculus, the hyaline cells more or less fibrillose in the upper third of leaf. Ramuli short, ascending or divergent, dense-leaved.

Synon.-Braithw. Sphag. Brit. Exsic. n. 48.

HAB. - In deep bogs on the northern peat-moors.

EuRoPE.-Carrington Moss, Cheshire (Hunt, r863); Wheeldale Moor, Goathland, Yorkshire (Anderson); Fowlshaw Moss and Broad Gate Bog, Staveley, Westmoreland (Stabler). Szveden: Hunneberg Mountain (Lindberg).

This beautiful plant when growing in large masses has a fine effect, and the strong dense-leaved branches present a marked contrast to the laxer forms of the species. It may be at once known by the fibrils in the upper part of the stem leaves, and the mode in which they terminate in a little contracted hollow point. 


\title{
I8. Sphagnum cuspidatum, Ehrhart.
}

\author{
PL. XXVI. AND XXVII.
}

Dioicous ; very soft, in loose submersed or floating tufts, pale or deep green. Stems slender, pale green; the cuticular cells in 2-3 strata. Stem leaves ovate-oblong, broadly bordered with very narrow elongated cells, hyaline cells of the upper half with numerous spiral fibres. Branches divergent, not concealing the stem; the leaves narrowly lanceolate, laxly imbricated, flexuose when dry. Spores ferruginous.

Synon.-Sph. palustris mollis deflexi, squamis capillaceis var. $\beta$. fuitans, DiLL. Hist. Musc. t. 32, fig. 2, B ( $174 \mathrm{I}$ ), et Herbar. fol. 32, specimen on the right.

Sph. cuspidatum, EhrH. Dec. Crypt. n. 25 I (I 79I). Rotr. Fl. Germ. iii. p. I 20 (1793). Hoffu. Deutschl. Fl. ii. p. 22 (I 796). SмIтh, Fl. Brit. p. II 47 (I804); Eng. Bot. t. 2092 (I8I9). Turn. Musc. Hib. p. 6 (1804). Brid. Sp. Musc. i. p. I7 (1806) ; Mant. Musc. p. 2 (I819), et Bry. Univ. i. p. I4 (1826). IVeB. MoHr, Bot. Taschenb. p. 74, t. 6, f. 2 (1807). Schkuhr, Deutschl. Moose, p. 16, t. 7 (1810). Schwägr. Suppl. I. pt. I, p. 16, t. 6 (I8II). Röhling, Deutschl. Fl. iii. p. 35 (18I3). Schultz, Suppl. Fl. Starg. p. 65 (I8Ig). Fl. Danica, t. I7I2 (I821). Gray, Nat. Arr. Br. Plants, i. p. 7 Io, 4 (I82 r). Swartz, Adnot. Bot.p. 74 (1829). Hüben. Musc. Germ. p. 29 (1833). Dozy, Molk. Prodr. Fl. Batav. p. 79 (I85I). Berkel. Handb. Br. Moss. p. 307 ( 1863 ). LindB. in Öfv. K. Vet. Ak. Förh. xix. p. I 35, n. I (1862). Schimp. Synops. ed. 2, p. 83 I (I 876). Hartm. Skand. Fl. ed. 3-6, et 8. Klingar. in Schr. K. Phys. Ekk. Gesel. zu Königs. I872, p. 6. Hobk. Syn. Br. Moss. p. 24 (1873). Braithw. Sphag. Brit. Exsic. n. 50 (1877).

Sph. capillaceum var. $\beta$. cuspidatum, WAHL. Fl. Lapp. p. 30I (1812); Fl. Suec. ed. 2 , p. 807 (1833).

Sph. laxifolium, C. Mürc. Synops. i. p. 97 (1849), et Deutschl. Moose, p. 126 (1853). Jensen, Bryol. Dan. p. 48, t. ii. fig. 9 (1856). Hartm. op. cit. ed. 7 , p. 399. Lindb. in Bot. Notis. 1856 , p. I 2 I. Schlieph. in Verh. Z. B. Gesel. Wien, 1865, p. 396 . MILDE, Bry. Siles. p. 385 (1869).

Sph. cuspidatum var. $\gamma$. WiLs. Bry. Brit. t. 4 (1855).

Sph. cuspidatum $\beta$. submersum, Sснгмр. Torfm. p. 61, t. xvi. fig. I $\beta$ (1858), et Synops: p. 676 (1860).

Dioicous; in loose submersed or floating tufts; plants very soft, light green, deep green, or more or less tinged with yellow or brown.

Stems slender, flaccid, pale green, 6-1 8 in. or sometimes several feet in length; cuticular cells not porose, larger, well defined, in 2-3 strata; those of the peripheral layers pale yellowish. Stem leaves ovate-oblong, pointed, with the margins involute at apex, broadly bordered with very narrow elongated cells, the hyaline cells of the upper half with numerous spiral fibres.

Branches $3-5$ in a fascicle, longer, often turned to one side and 
falcate at points; all divergent, cuspidate with the convolute terminal leaves, or $\mathrm{I}-2$ pendent, but not concealing the stem, those of the coma few and more lax; retort cells elongated.

Branch leaves laxly imbricated, narrowly lanceolate, flexuose when dry, often somewhat falcato-secund, 3-6 toothed, and with a broader border of narrow cells; hyaline cells elongated, with annular and spiral fibres and few pores, chlorophyllose cells free on the posterior surface, trigono-elliptic in section.

Capsules in the capitulum, or scattered on the stem, the peduncles being often much elongated. Perichætial bracts distant from each other, very broadly oval, involute at apex, laxly areolate, with fibres in the upper cells. Spores ferruginous.

Male plants more slender, amentula fusiform, yellowish brown; the bracts ovato-lanceolate.

HAB.-Stagnant pools in moorlands; frequent. Fr. July.

Europe and N. America generally distributed.

The chief points of distinction between this species and the last are as follows: in Sph. cuspidatum the plants are more slender, the pendent branches not closely appressed to stem, the cuticular cells of the stem well defined from the thicker peripheral layer; the longer branch leaves not recurved when dry, but slightly flexuose; the stem leaves with larger cells, fibrillose in the upper part, and narrower more elongated ones at the margin; the more obtuse perichrtial bracts, and lastly the brown spores. It must also be borne in mind that the two plants not unfrequently grow together, yet each retaining its special features.

Var. $\beta$. falcatum, Russow.

More or less submersed, deep green or brownish green. Branches nearly equal, and especially in the capitulum subsecund, arcuate at apex. Branch leaves narrowly lanceolate, the terminal ones falcate.

Svnon.-Sph. cuspidatum var. є. falcatum, Russ. Beitr. zur Kennt. Torf. p. 59 (1865). Schimp. Synops. ed. 2, p. 832. Braithw. Sphag. Brit. Exsic. n. 5 r.

Sph. hyproides, Braun, in Bot. Zeit. 1825 , No. 40 . Brid. Bry. Univ. i. p. 752 (a young undeveloped state of the plant).

Sph. cuspidatum var. hypnoides, Schimp. Torfm. p. 61, t. I6, f. є.

HaB.-In deep pools. Not unfrequent.

In its extreme form this constitutes a well-marked variety, but transition states exist which gradually connect it with the type. 
Var. $\gamma \cdot$ plumosum, NEEs, Hsch.

Submersed, slender, flaccid, elongated; branches decurved, all uniform and divergent, with long, lanceolato-subulate, soft leaves. Perichretia elongated with distant leaves.

Synon.-Sph. cuspidatum var. plumosum, NeEs, Hsch. St. Bry. Germ. p. 24, t. iv. f. $9^{*}$. BRID. Bry. Univ. i. p. 15. Schimp. Torfm. p. 6r, pl. xvi. $\delta$; Synopls. p. 676 , et ed. 2, p. 832 . Russow, Beitr. p. 60 .

Sph. cuspidatum var.mollissimum, Russow, Beitr. p. 6 I (a dense, yellowish form).

Sph. laxifolium var. serrulatum, Schliep. in Verh. Z. B. Gesel. Wien, 1865, p. 396 (a form with the margins of leaf serrulate).

HAB.-In deeper water, rarely bearing fruit.

Plants wholly submersed, elongated sometimes to a length of two feet, at others with the fascicles closely approximated and then resembling a tuft of confervæ; the latter form has been found near Todmorden by the late J. Nowell, and is Russow's var. mollissimum.

Var. $\delta$. brevifolium, LindB.

Stems firm, 5-6 in. high, pale yellowish green; stem leaves short, ovate, obtuse, with a few irregular teeth at apex; cells fibrillose in the apical part, the marginal cells very narrow and elongated. Branches in close-set fascicles, short, ascending and divergent, arcuato-decurved from the middle, attenuated toward the points; the leaves subsecund when dry, spreading and imbricated when moist, short, ovate, somewhat oblique and unequal-sided, the apex truncate, 5 -toothed.

Synon.-Sph. curvifolium, Hunt, in Herb. suo.

Sph. Laricinum, Schimp. Synops. ed. 2, p. 845 (the Loch Kandor specimens).

Sph. cuspidatum var. brevifolium, LINDB. in lit. BRAITHW. Sphag. Brit. Exs. n. 53 .

HAB.-Deep bogs.

England: Carrington Moss, Cheshire (Hunt). Scotland: Near Loch Kandor, Aberdeenshire (Hunt).

This plant at first sight very much resembles a pale form of Sph. laricinum, but a microscopic examination soon shows us that it differs in structure from that species, and constitutes a very peculiar variety of $S$. cuspidatum, having both the stem leaves and branch leaves shorter than usual. The plant figured in Sullivant's Icones Musc. Suppl. t. 2, as S. cuspidatum var. appears to stand midway between the present plant and the normal form of the species. 
Var. $\epsilon$. Torreyi (Sulliv.), Braithw.

Robust, in lax floating tufts, rigid, 8-I 6 in. high, of a reddish brown colour. Branches 4-5, attenuated, their leaves very large, elongato-lanceolate, tubulose and toothed at apex, the hyaline cells with numerous minute pores. Stem leaves large, deltoid, without fibres.

Synon.-Sph. Torreyanum, Sulliv. Mem. Amer. Acad. n. s. iv. p. 175 (1849); Mosses of Un. St. p. I3, D. I6 (1856); Musc. Bor.-Amer. n. 9 (1856).

Sph. auriculatum, LesQ. in Mem. Calif. Ac. Sc. i. pt. I, p. 4 (1867). Suld. LesQ. Musc. Amer. Exsic. n. 23.

Sph. Mendocinum, Sull. LeSQ. Icon. Musc. Suppl. p. 12, t. 3 (1874).

Sph. cuspidatum var. $\delta$. Torreyi, Bratrhw. in M. Micr. Journ. Feb. I875, p. 64.

HAB.-N. AmERICA : Ponds in pine barrens of New Jersey (Torrey); California, in great bogs at 8000-9000 feet, near King's River (Brewer); Swamps near Mendocino City (Bolander).

Sect. II.-Hemitheca, Lindb.

Plants of peculiar habit, somewhat resembling that of Hypmum sarmentosum or stramineum, firm, slender, and elongated. Branches lateral, solitary or sometimes in pairs, short, distant, slender, subclavate, obtuse, arcuato-decurved. Leaves and perichæetial bracts alike, ovate-oblong, obtuse, with very large chlorophyllose cells, and densely annulate, non-porose hyaline cells. Capsule very small, after the fall of the large operculum, hemispherical, wide-mouthed, resembling that of a Physcomitrium.

\section{Sphagnum Pylaiei, Bridel.}

\section{Pr. XXVIII.}

Dioicous; stem simple, with a single layer of cuticular cells; branches solitary, or sometimes two or three together, slender, uniform, deflexed. Stem leaves and branch leaves alike; oblongovate, very concave, entire, obtuse; chlorophyllose cells oval in section, free both in front and back. Capsule immersed, on short lateral branches, hemispherical when empty.

Synon.-Sph. Pylaesii, Brided, Bryol. Univ. i. p. 749 (1826). Sullivant, Icon. Musc. p. 12, t. 6 (1864), et Suppl. p. I5, t. 6 (1875). Ausrin, Musc. Appal. No. 23 (1870).

Sph. sedoides var. Suld. LesqX. Musc. Bor.-Amer. No. 4 (1856). Sull. Mosses of Un. St. p. 12 (1856).

Sph. cymbifolium, forma juvenilis, C. MOLL. Synops. i. p. 92 (1849).

Dioicous; olive green, fuscous or blackish. Stem erect, slender, undivided, $3^{-6} \mathrm{in}$. high, with a single layer of small cuticular cells, and a narrow reddish-brown peripheral layer. 
Stem leaves numerous, resembling the branch leaves, erect, ovate-oblong, concave, rounded and minutely erose at apex, the hyaline cells fibrillose.

Branches solitary, or 2-3 in a fascicle at the lower part of stem, short, terete, obtuse, arcuato-decurved, the cuticular cells small, the retort cells few, narrowly cylindric, not recurved at apex.

Branch leaves laxly imbricated, very small, ovate, obtuse, the margin incurved in the upper third, entire at apex; hyaline cells with strong annular fibres, and without pores, in section circular, separated both in front and back by the chlorophyllose cells, which are very thick and oval or obtusely trigonous in section.

Capsules immersed on shorter lateral branches on the upper third of stem, small, globose; perichætial bracts rather lax, similar to the leaves, but longer.

Male plants more slender, amentula somewhat inflated, on the upper branches, the bracts resembling the branch leaves.

$\mathrm{HAB}_{\mathrm{A}}$ - Peat-bogs and stagnant pools.

N. America. - Newfoundland (La Pylaie); Table Rock, S. Carolina (Les: quereux); Willey Mountain, New Hampshire (James); Adirondack Mountains, New York (Peck); New Jersey (Austin).

Var. $\beta$. sedoides (BRID.), LINDB.

Synon.-Sph. sedoides, Brid. Bry. Univ. i. p. 750, et var. prostratum (1826). Suld. Musc. Allegh. n. 208 (1845). Suld. Lese. Musc. Bor.-Amer. n. 3 (I856). Sull. Mosses of Un. St. p. 12, n. 8 (1856), et Ic. Musc. p. Ir, t. 6 (1864). AustiN, Musc. Appal. n. 24 (1870).

Stem procumbent at base, ascending, $3-5$ in. high, simple or with a few short scattered branches, fragile, flaccid, dull pale green, the upper part vinous red. Leaves large, very densely imbricated, oblong-ovate, concave, obtuse, entire or eroso-denticulate, with a border of two rows of extremely narrow cells; hyaline cells elongated, with annular fibres, and a very few minute pores. Branch leaves similar, but smaller.

HAB.-Peat-bogs. Newfoundland (La Pylaie); wet margins of Table Rock, S. Carolina (Gray and Lesquereux); Mount Marcy, New York (Torrey) ; Adirondack Mountains, New York (Peck).

Sph. Pylaiei and its variety have been regarded by most authors as doubtful species, but the form and position of the fruit, and the structure of the leaves and stem are so distinct, that there can be no hesitation in maintaining its right not only to specific 
rank, but also to that of a separate section in the genus, as indicated by Professor Lindberg under the appropriate title of Hemitheca.

The var. sedoides bears the same relation to the type as the var. cyclophyllum does to Sph. laricinum. Perhaps the most singular feature of the plant is the very small capsule, which appears to have been overlooked until collected by Austin, and even when present, some care is required before it can be detected, so completely is it concealed by the perichrtial bracts.

\section{Sect. III.-Isocladus, Lindb.}

Plants whitish, glossy, resembling some species of Leucobryum, rigid, fragile. Branches acute in distant fascicles of 2-5, all arcuato-divergent, subclavate. Branch leaves very large, accrescent, distant, spreading, lanceolate; the cells very narrow, serpentine, without fibres, but with a central longitudinal series of pores. Perichætial bracts divergent, resembling the leaves in structure.

\section{Sphagnum macrophyllum, BernHardi.}

\section{PL. XXIX.}

Dioicous; pale olive green, glossy, shining. Branches uniform, divergent, lax-leaved. Stem leaves minute, ovate-oblong, obtuse. Branch leaves narrowly lanceolate-subulate, toothed at apex; hyaline cells narrow, elongated, without fibres, and with 6-ro pores in a longitudinal median line; chlorophyllose cells circular, separating the hyaline both in front and back.

Synon.-Sph. macrophyllum, BeRnh. Brid. Bryol. Univ. i. p. ro (1826). Drumm. Musc. Amer. Coll. 2, n. r 8 (r84r). Sulliv. Musc. Allegh. n. 207 (1845); Mosses of Un. St. p. r2, n. ro (r856), et Ic. Musc. p. r, t. I (1864). C. MUll. Synops. i. p. 91 (1849). Suld. LesQ. Musc. Bor.-Amer. n. I (1856). Austin, Musc. Appal. n. $4 \mathrm{r}(\mathrm{1} 870)$.

Isocladus macrophyllus, Lindb. Öfv. af K. Vet. Ak. Förh. xix. p. I33 (I862).

Dioicous, pale olive green, fuscescent below; when dry, glossy and shining.

Stems 6-ro in. high, rather rigid, very fragile, fuscous, simple or dichotomous by innovation, with $2-3$ layers of cuticular cells, and small, yellowish peripheral cells.

Stem leaves minute, very broad at base, ovate-oblong, obtuse, entire; the hyaline cells rhomboid, without fibres, but with $1-3$ central pores.

Branches crowded in a spinose capitulum, 3-4 in a fascicle, 
uniform and similar, divergent, dependent, straight, subflabellate, lax-leaved, the cuticular cells short, uniform, with few pores.

Branch leaves rather rigid, subdistichous, small at base of branch, soon becoming elongated, narrowly lanceolate and lanceolate-subulate, involute-concave, bordered by $\mathrm{I}-2$ rows of extremely narrow cells; apex somewhat truncate, with 7-8 teeth. Hyaline cells elongated, flexuoso-fusiform, with 6-1o pores in a longitudinal median line, free from fibres; chlorophyllose cells circular in section, separating the hyaline both in front and back.

Fruit in the upper fascicles or in the coma, divergent; perichætial bracts $6-9$, lax oblong-ovate, uppermost convolute, truncate and toothed at apex, the areolation resembling that of the branch leaves. Capsule small, on a shortish slender peduncle. Spores sulphur-coloured.

Male plant and prothallium unknown.

HaB.-Sandy bogs. Rare.

N. America.-Near Philadelphia (Bernhardi); Swamps in Louisiana (Drummond); Raccoon Mountains, Alabama (Lesquereux); Green County (Mississippi (Tice); New Jersey (Austin); Wilmington, N. Carolina (Sullivant).

Quite peculiar among the Sphagna, by the uniform branches, the slender pendent ones, ordinarily present, being wanting, and also by the central position of the pores, and total absence of fibrils.

In general aspect it resembles the plumose state of Sph. cuspidatum, or even some forms of Hypnum fluitans, to which also the areolation at first sight somewhat approximates.

\section{ADDENDA.}

Sph. tenellum var. Longifolium.

Snowdon, near Llanberis (Boswell, x 874).

Sph. magnifolium, WILs. Mss. in Herbar. suo, probably also Sph. Kinlayanum, WiLS. in schedis.

Ben Wyvis, Ross (McKinlay).

I can see in this only a form of Sph. subsecundum var. contortum, having very large stem leaves, evidently developed at the expense of the branches, which are few and distant or nearly absent; the comal branches are, however, quite normal. 


\section{N D E X.}

[The Synonyms are in Roman Type.]

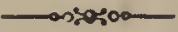

\begin{tabular}{|c|c|c|c|c|c|c|}
\hline & & & & & & PAGR \\
\hline Antheridia .. & .. & .. & .. & .. & .. & .. 20 \\
\hline Antherozoids & .. & .. & .. & .. & .. & $2 \mathrm{I}$ \\
\hline Archegonium & .. & .. & .. & .. & .. & .. \\
\hline Areolation .. & .. & .. & .. & .. & .. & .. \\
\hline Arrangement 0 & f spe & cies & .. & .. & .. & .. 25 \\
\hline Bracts .. $\quad$.. & .. & .. & .. & .. & .. & I9, 2 I \\
\hline Branches .. & .. & .. & .. & $\therefore$ & .. & .. $\quad$ I4 \\
\hline Calyptra .. & .. & .. & .. & .. & .. & .. \\
\hline Capsule $\quad$.. & .. & .. & .. & .. & .. & .. 23 \\
\hline Chlorophyllose & cells & & .. & .. & .. & 16,18 \\
\hline Clavis to speci & & .. & .. & .. & .. & .. 29 \\
\hline Cuspidata .. & .. & .. & .. & .. & .. & .. \\
\hline Cuticle .. & .. & .. & .. & .. & .. & .. \\
\hline Cymbifolia & .. & .. & .. & .. & .. & .. \\
\hline Eusphagnum & .. & .. & .. & .. & .. & $3 I$ \\
\hline Examination & .. & .. & .. & .. & .. & .. 7 \\
\hline Exosporc .. & .. & .. & .. & .. & .. & 12,24 \\
\hline Exotic species & .. & .. & .. & .. & .. & .. 8 \\
\hline General observ & ration & & .. & .. & .. & .. \\
\hline Gcrminal cell & .. & .. & .. & .. & .. & $\because$ \\
\hline Germination & .. & .. & .. & .. & .. & .. \\
\hline Hemitheca & .. & .. & .. & .. & .. & .. 85 \\
\hline Hyaline or ves & icula & $\mathrm{r}$ cel & & .. & .. & 16,18 \\
\hline Intermediate le & eaves & .. & .. & .. & .. & .. 17 \\
\hline Isocladus .. & .. & .. & .. & .. & .. & .. 87 \\
\hline Lcaves $\quad .$. & .. & .. & .. & .. & .. & .. \\
\hline Literature of th & he sul & bject & .. & .. & .. & .. \\
\hline Lumen $\quad$.. & .. & .. & .. & .. & .. & .. \\
\hline Operculum & .. & .. & .. & .. & .. & .. \\
\hline Papilla .. & .. & .. & .. & .. & .. & .. \\
\hline Paraphyses & .. & .. & .. & .. & .. & .. 21 \\
\hline Pores .. .. & .. & .. & .. & .. & .. & 16,19 \\
\hline Prothallium & .. & .. & .. & .. & .. & .. 12 \\
\hline Reproductive s & ysten & & .. & .. & .. & 20 \\
\hline
\end{tabular}

\begin{tabular}{|c|c|c|c|c|}
\hline & & & & \\
\hline Retort cells & .. $\quad$. & .. & 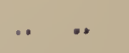 & .. \\
\hline Roots .. .. & .. $\quad .$. & .. & .. & .. \\
\hline Sphagninæ & .. $\quad .$. & .. & .. & .. \\
\hline Sphagnum .. & .. $\quad$. & ... & .. & .. \\
\hline Sphagnum acu & tifolium, & Ehrh & h. .. & .. \\
\hline$"$ & $"$ & var. & arctum & .. \\
\hline " & $"$ & $"$ & deflexum & \\
\hline$"$ & $"$ & " & elegans & \\
\hline " & $"$ & $" J$ & ftuscum & .. \\
\hline " & $"$ & 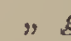 & gracile & .. \\
\hline$"$ & " & $" 7$ & late-viren & \\
\hline " & $"$ &, 1 & laxum & .. \\
\hline " & $"$ & $"$ & luridum & .. \\
\hline$"$ & $"$ & $" 2$ & patulume & .. \\
\hline$"$ & $"$ & $" 2$ & purpueveu & \\
\hline$"$ & $"$ & $" 9$ & $\begin{array}{l}\text { guinque- } \\
\text { farium }\end{array}$ & \\
\hline$"$ & $"$ & $"$, & rubellum & \\
\hline$"$ & $"$ & & $\begin{array}{l}\text { subfimbrio } \\
\text { tum .. }\end{array}$ & 65 \\
\hline$"$ & $"$ & " t & tenellum & .. \\
\hline$"$ & " & $"$ & teneue & .. \\
\hline
\end{tabular}

Sphagnum Aconiense, De Not. $\quad . . \quad$.. 59 albescens, Hüb. .. $\quad . . \quad$.. 79 ambiguum, Hüb. .. $\quad . .56$ Sphagnum Angströnii, Hartm. .. .. Sphagnum Ascherbachianum, Breut. .. 67 " auriculatum, Schimp. .. .. 50 $\begin{array}{lllll}\text { Sphagmem Austini, Sull. } \quad . . & \text {.. } & \text {.. } & 33\end{array}$ Sphagnum capillaceum, var. Suricatum .. 34 $\begin{array}{ccccc}\text { Sphagnum capillaceum, Swtz. } & \text {.. } & \text {.. } & 67 \\ \text { " capillifolioides, Breut. .. } & \text {.. } & 67\end{array}$ capillifolium, Ehrh. .. $\quad$.. 66 $\begin{array}{lll}\text { cochlearifolium, Wils,.. } & . . & 47\end{array}$ 
Sphagnum compactum, De C. ... 41 , ",$\quad$ var. ramulosum 53 " " $\quad$ " rigidum .. 56 " condensatum, Schlcich. .. 58 " contortum, Schultz .. $\quad . .50$ $" \quad$ " var. obesum $\quad . \quad 5$ I " " "subsecundum 48 " crassisetum, Brid. $\quad$.. $\quad$.. 59 " curvifolium, Wils. .. .. 45 "; cuspidatiforme, Breut... .. 79 Sphagnum cuspidatum, Ehrh. $\quad$.. $\quad$.. 82 " $\quad$ var. brevifolium 84 " $\quad$ " $\quad$ falcatum .. 83 " $"$ " fallax .. 8 r $" \quad " \quad$ " hypnoides 83 " " " majus .. $8 \mathrm{r}$ " " $\quad "$ mollissimum 84 " " " plumosum 84 " " " riparium 80 $" \quad " \quad$ " speciosum 8 r " " "Torreyi .. 85 $\begin{array}{llll}\text { Sphagnum cyclophyllum, Sull. } \quad \text {.. } & \text {.. } & 47\end{array}$ " cymbifolioides, Breut... .. 4 I I Sphagusm cymbifolium, Ehrh. .. $\quad$.. 38 " " var. compactum 4I $" \quad "$ " congestum 40 " $" \quad$ " cordifolium 52 $" \quad$ " purpurascens 40 " " "squarrosulum $4 \mathrm{I}$ " " " tenellum 42,50 " " " turgidum 36,47 Sphagnum denticulatum, Brid. .. $\quad$.. 50 " Drummondii, Wils. $\quad . . \quad$.. 47 " dubium, Wils, .. $\quad$.. $\quad$.. 79 Sphagnum fimbriatum, Wils. .. $\quad$.. 63 $" \quad$ " var. majus .. 64 " " " robustum .. 6t Sphagnum flexuosum, Dozy .. $\quad$.. $\quad$.. 79 $\begin{array}{lllll}n & \text { fulvum, Sendt. } \quad \text {.. } & \text {.. } & \text {.. } & 77\end{array}$ " $\quad$ fuscum, Klingg. $\quad$.. $\quad$.. $\quad . .73$ " Girgensohnii, Russ. .. .. 64 " " var.squarrosulun 66 " helveticum, Schk. .. $\quad . . \quad 58$

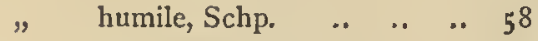
" hypnoides, Braun .. .. 83 " imbricatum, Hornsch. . .. 35 " immersum, Nees .. $\quad . . \quad$.. $\quad 56$ " $\quad$ " $\quad$ Casseb. .. $\quad . .36$ " insulosum, Angst. $\quad$.. $\quad . . \quad 52$ Sphagnum intermedium, Hoffm. .. .. 78 " $\quad$ var. pulchrum 8r
PAGA Sphaguum intermedium, var. riparium 80 Sphagnum Kinlayanum, Wils. $\quad . . \quad$.. 88 $\begin{array}{lllll}\text { Sphagmum laricinum, Spruce } \quad \text {.. } & \text {.. } & 44\end{array}$ " var. cyclophyllum 47 " " platyphyllim 47 " teretiusculum 46

Sphagnum latifolium, Hedw. .. $\quad$.. $\quad$.. 39 var. fluitans $\quad . .50$ laxifolium, C. Müll. .. $\quad . . \quad 82$ var. scrrulatum .. 84 Lescurii, Sull. $\quad$.. $\quad$.. $\quad$.. 50 Sphagnum Lindbergii, Schp. I .. $\quad$.. 77 ". macrophyllum, Brid. .. .. 87 Sphagnum magnifolium, Wils. $\quad . . \quad$.. 88 " mendocinum, Sull. .. $\quad . .85$ Sphagnum molle, Sull. ..

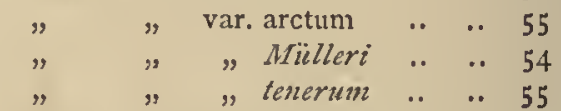
Sphagnum molluscoides, C. Müll. $\quad$.. 55 " molluscum, Bruch. .. $\quad . .42$ " $"$ var. inmmersum 44 " Mougeotii, Schimp. .. $\quad$.. 79 " Mülleri, Schimp. .. $\quad$.. $\quad$.. 55 " neglectum, Angst. $\quad$.. $\quad$.. 45 $\begin{array}{lllll} & \text { oblongum, P. B. .. } & \text {.. } & \text {.. } & 59\end{array}$ " obtusifolinm, Ehrh. .. .. 39 " $\quad$ var. minus .. 58 " obtusun, Warnst. $\quad . . \quad$.. 8 I " palustre, L. .. $\quad . . \quad$.. $\quad 39,66$ Sphagnum papillosum, Lindb. .. $\quad$.. 35

" " var. confertum 37 " " , stenophyllum $3^{8}$ $\begin{array}{lllll}\text { Sphagnum patulum, Mitt. } \quad . . & \text {.. } & \text {.. } & 59\end{array}$ " pentastichum, Brid. .. .. 67 " platyphyllum, Sull. .. $\quad . .47$ " porosum, Lind. .. $\quad$.. $\quad$.. 62 Sphagnum Portoricense, Hampe .. .. 32 Sphagnum præmorsum, Zenk. Diet. .. 58 " $\quad$ pycnocladum, Angst. .. .. 75 Sphagnum Pylaiei, Brid. $\quad$.. $\quad$.. $\quad$.. 85 " " var. sedoides .. .. 86 $\begin{array}{lllll}\text { Sphagnum recurvum, P. B. } & \text {.. } & \text {.. } & \text {.. } & 78\end{array}$ Sphagnum rigidum, Nees $\quad . . \quad$.. $\quad . .56$ " " var. compactum .. 57 $\begin{array}{cccc}\text { Sphagnum riparium, Angst. .. } & \text {.. } & . & 81\end{array}$ rubellum, Wils. $\quad . . \quad$.. $\quad$.. 69 scdoides, Brid. $\quad$.. $\quad$.. $\quad$.. 86 speciosum, Klingg. .. .. $8 \mathrm{I}$ spectabile, Schimp. .. $\quad$.. 81 
PAG

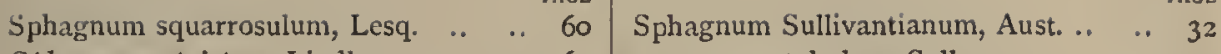

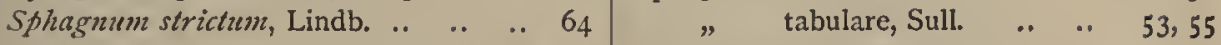
" $\quad$ var. squarrosulum 66 Sphagnum tenellum, Ehrh. .. .. . . 42 $\begin{array}{lllllllllll}\text { Sphagnum strictum, Sull. } & . & . & . & 58 & \text {. } & & \text { var. fluitans } & \text {.. } 44\end{array}$ Sphagnum squarrosum, Pers. .. $\quad . .59 \quad 59 \quad$ " $\quad$ " $\quad$ "longifolium .. 44

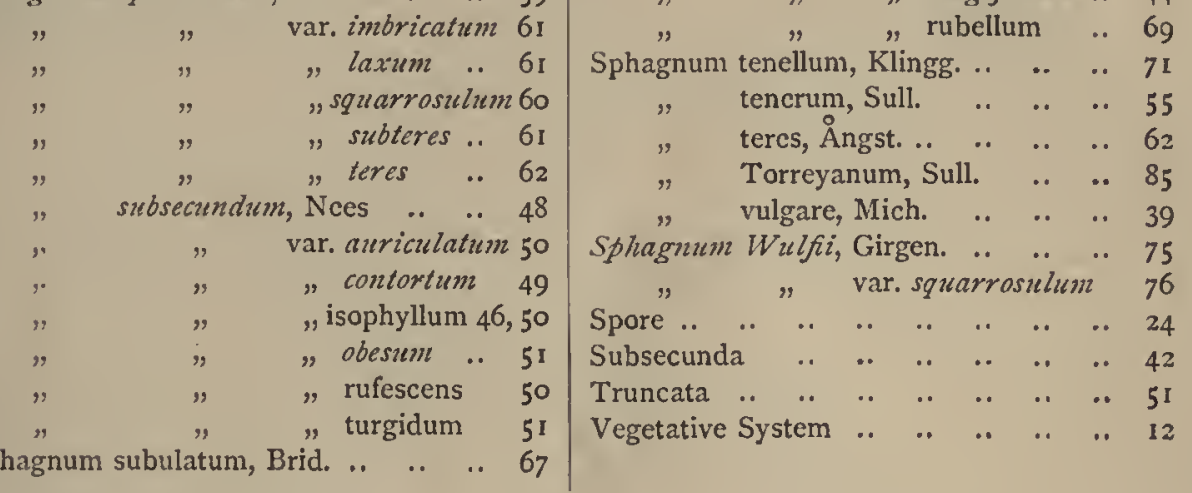



PLATE I. 


\section{PLATE I.}

(Fig. I from a Specimen lent by Mr. Howse, the rest from Schimper's work.)

FIG. I.-Prothallium with young plant.

"2.-Sph. cymbifolium. Vertical section of stem, passing also through two leavcs and the base of a branch fascicle.

"3.-Ditto. Transverse scction showing the pith or axile cells, the indurated pcripheral layer, and the four strata of cuticular cells.

" 4.-Cclls of pith. FrG. 5.-Ditto of woody layer. FIG. 6.-Ditto of cuticle.

"7.-Cells of a branch leaf of Sph. cymbifolium.

"7x.-Transverse section of a leaf of Sph. squarrosum.

" 8.-Cells of a branch leaf of $S p h$, acutifolium seen from the back.

" $8 x$.-Transverse section of same.

" 9.-Male inflorescence of Sph. cymbifolium. FIG. I0.-Ripe antheridium with paraphyses.

"11.-Vertical section of a capsule still cnclosed in the calyptra. $c$, calyptra ; s, cavity of sporc sac ; $\not$, pedicel of capsule.

"12.-Macrospores. FIG. 13.-Microspores. 
का

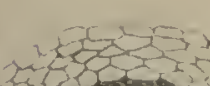

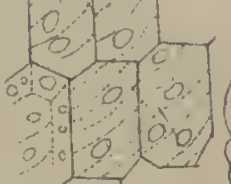

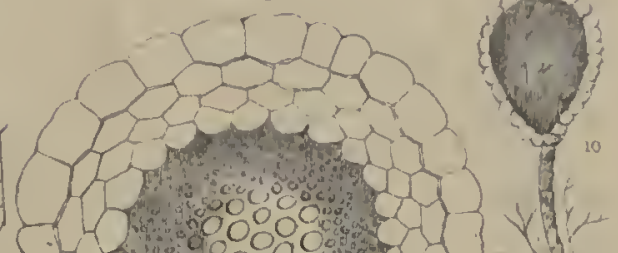
$\left\{\begin{array}{c}900004 \\ 0,0000\end{array}\right\}$

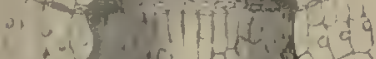

at 54 th ices

$f+1,1+\frac{1}{5}$

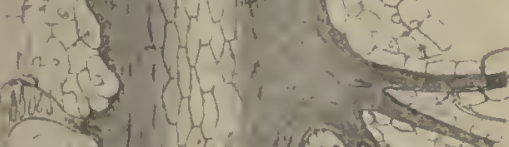
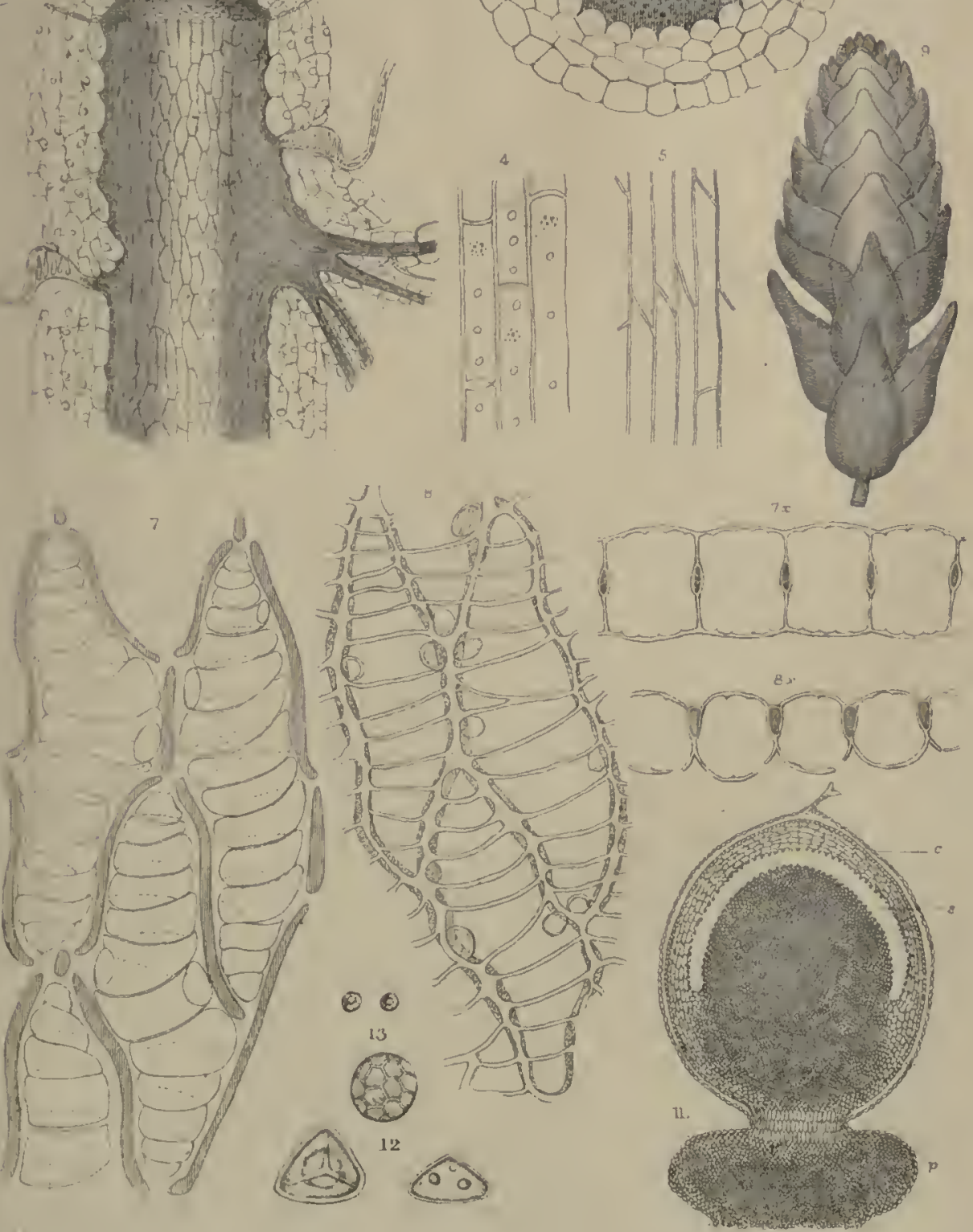

PLATE II. 


\section{PLATE II.}

\section{Sphagnum Portoricense, Hampe.}

FIG. a.-From a plant in Austin's collection.

" I.-Part of stem with a branch fascicle.

"5.-Stem leaves. FIG. 5 a a.-Areolation of apex of same.

"6.-Leaf from middle of a divergent branch. FIG. $6 x_{0}$ - Section of samc. FIG. $6 c .-$ Cell from middle $\times 200$. FIG. 6b. - Leaves from base of the same branch. FIG. 8.-Leaf from a pendent branch.

"9x.-Part of section of stem.

"I0.-Part of a branch denuded of leaves. FIG. 10a.-Cuticular cells of same. FIG. Iob. - The same seen laterally. FIG. I0x.-Transverse scction of a branch. 


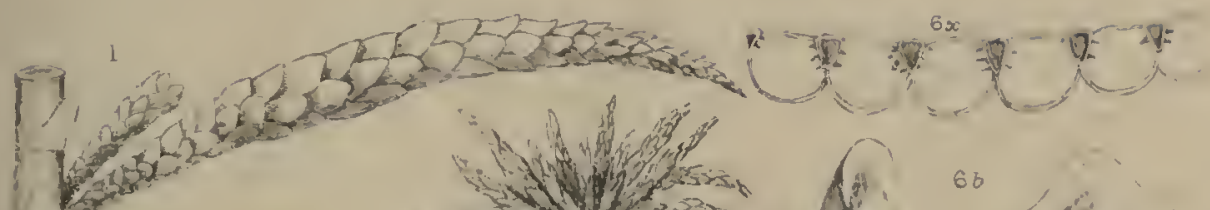

1

a

$$
\text { i }
$$
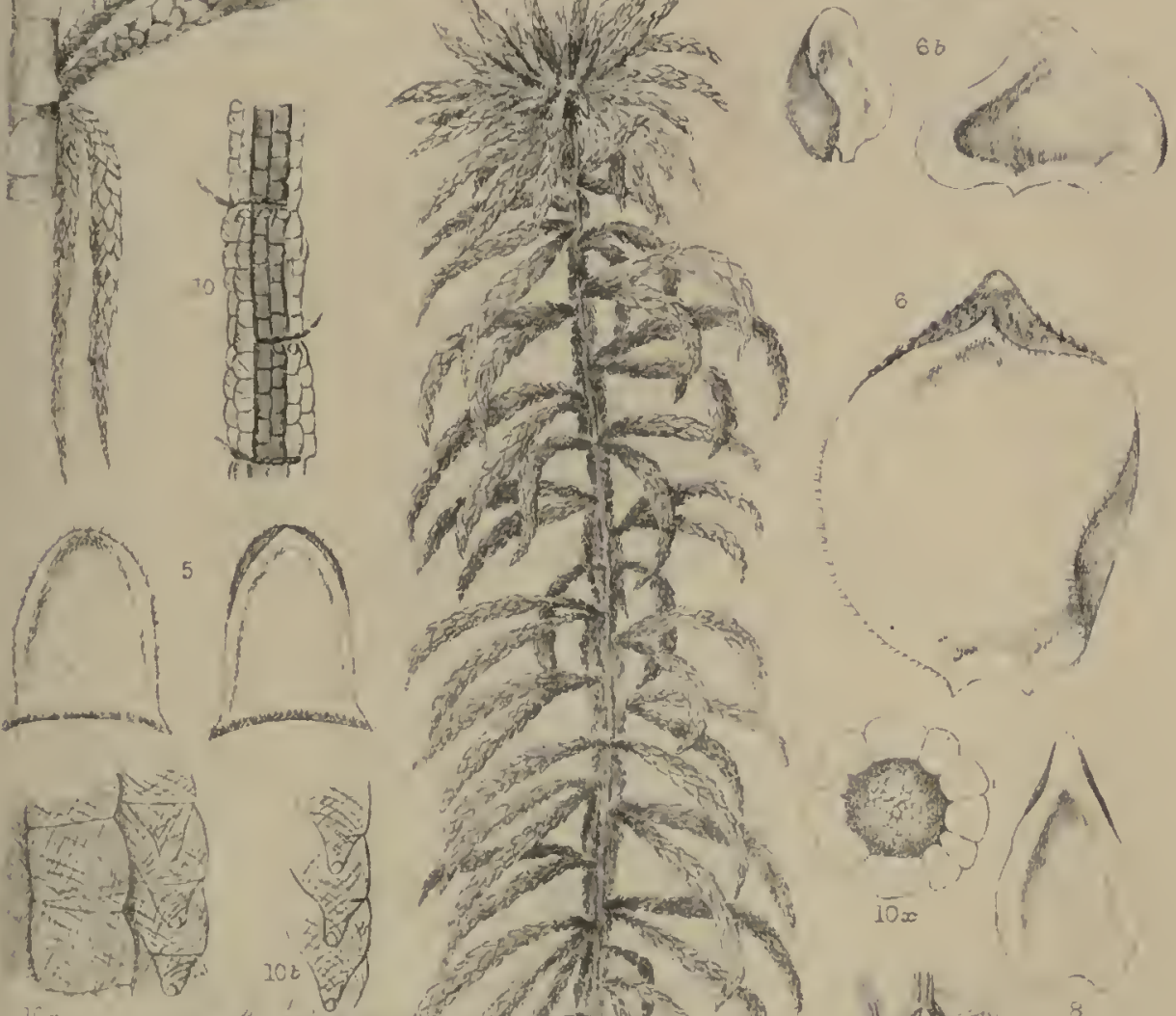
- $20 \times$, f $x \times 2 \times$. $+4 \times 2 \times$ H Mn onh:

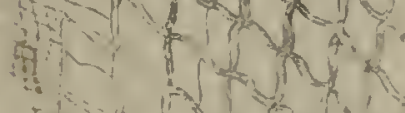
- $x^{2}+y^{2}$ What
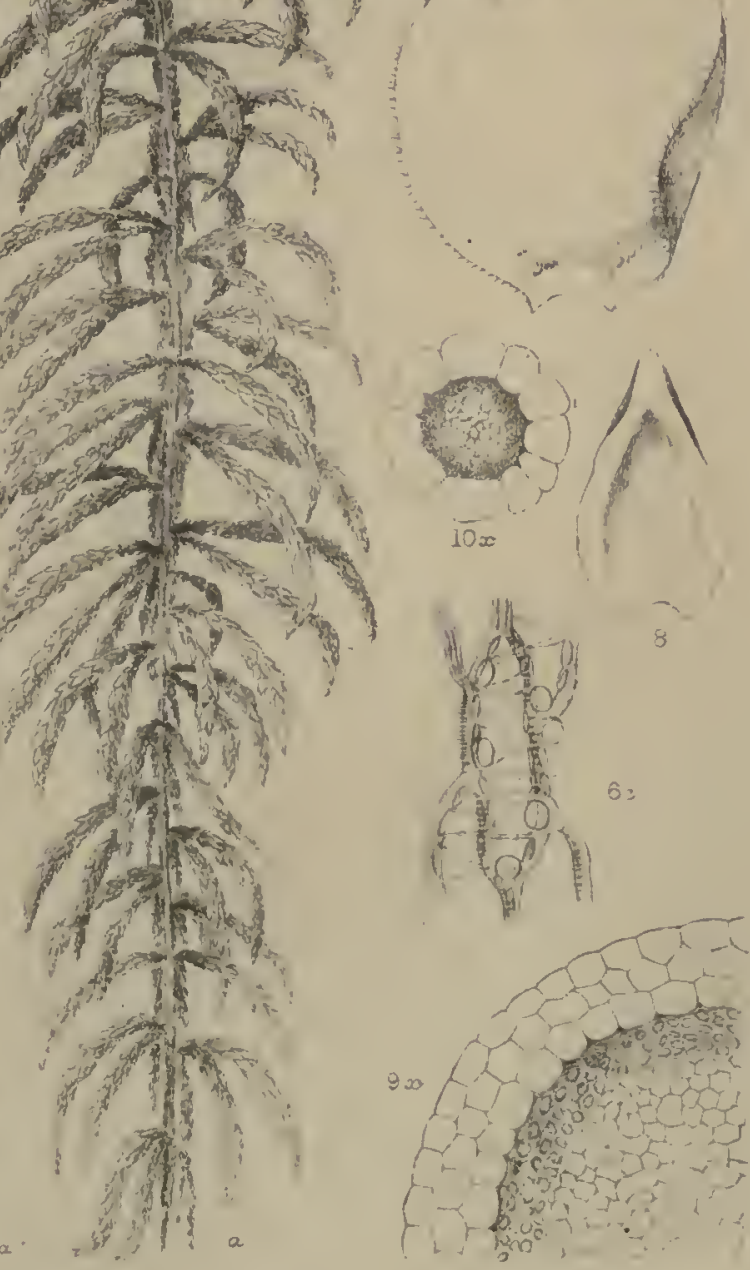

PLATE III. 


\section{PLATE, III.}

\section{Sphagnum Austini, Sull.}

F1G. a. - Female plant from Austin's collection.

, b.-Barren plant from Hunneberg.

"1.-Part of stem and branch fascicle.

" 3.-Perichætium and fruit. FIG. 4.-Perichretial bract.

"4c.-Cell from middle of same $\times 400$.

" 5.-Stem leaves. FIG. 6.-Leaves from a divergent branch.

"6p.-Point of same. FIG. $6 a a_{0}$-The same expanded under pressure. FIG. 6x.Transverse section.

"6c.-Cell from middle $\times 200$.

" $6 \mathrm{cl}$.- Hyaline cell scen from the side in adhesion to the wall of the chlorophyllose cell (Lindberg).

" 7.-Basal internediatc leaves. FIG. 8.-Leaf from a pendent branch.

" 9x.-Part of section of stem.

"9c.-Outer cuticular cells of stem. $9 c^{\prime}$.-Inner ditto $\times 100$.

"10.-Part of a branch denuded of leaves.

"IOc.-Cuticular cells of samc. 


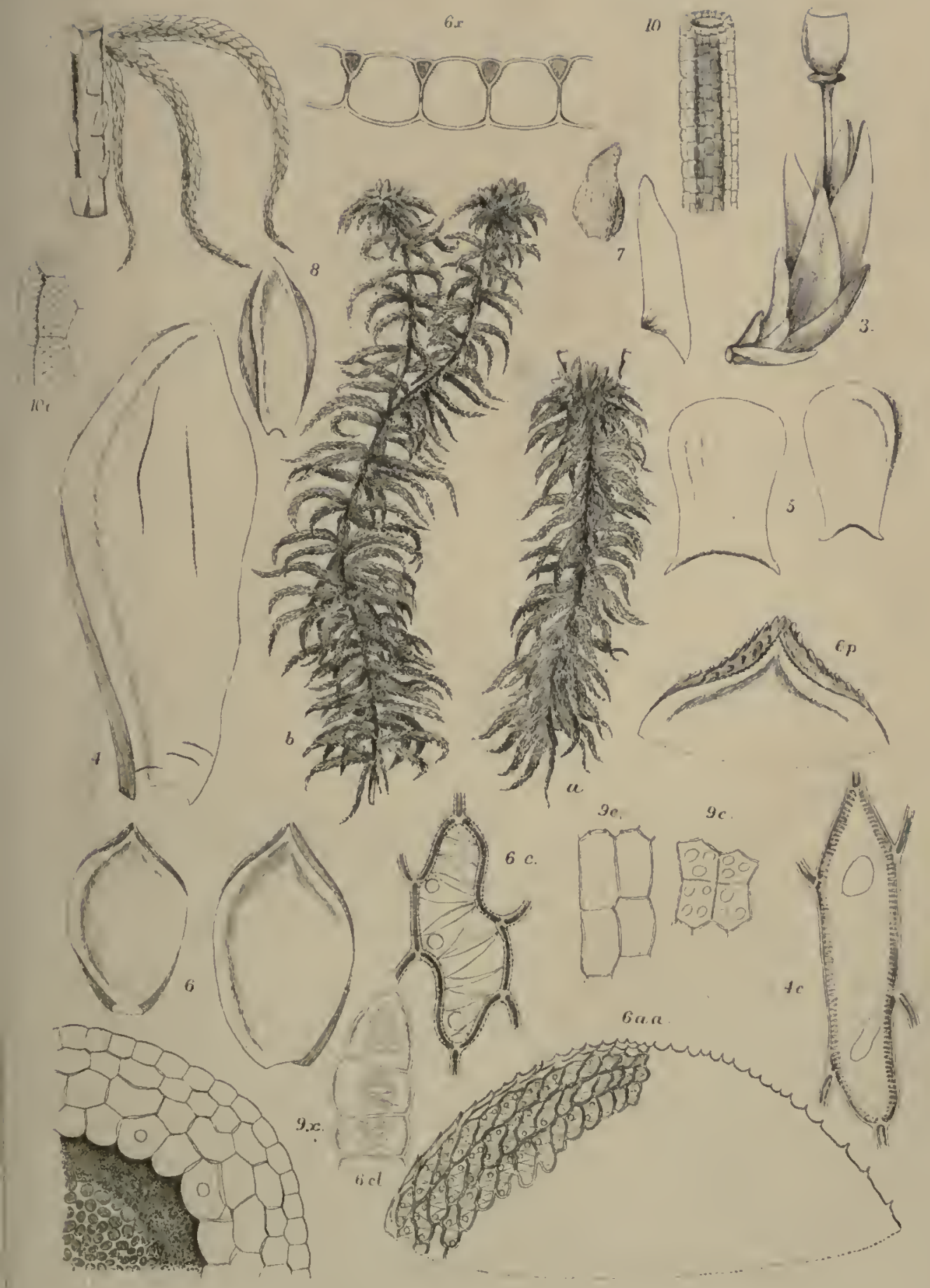



PLATE IV. 


\section{PLATE IV.}

Sphagnum Papillosum, Lindb.

FIG. a.-Female plant. FIG. $a$ t.-Part of male plant.

"1.-Part of stem with a branch fascicle.

" 2.-Male inflorescence. FIG. 2b. - Bract from saine.

"3.-Fruit with its perichætium. FIG. 4.-Bract from same.

$" 4 b a$.-Areolation of basal wing of same.

" 5.-Stem leaf.

"6.-Branch leaf. FIG. 6p.-Point of samc. FIG. 6x.-Transverse section. FIG. 6 a a.-Areolation of half of apex, expanded under pressure. FIG. 6c.Ccll $\times 200$.

" $6 c l$. - Hyaline cell seen from the side in adhesion to the wall of the chlorophyllose cell (Lindberg).

"6y.-Branch leaf of var. stenophyllum.

"7.-Basal internediate leaves.

"9x.-Part of section of stem. FiG. 9c.-Outer cuticular cclls of same. 


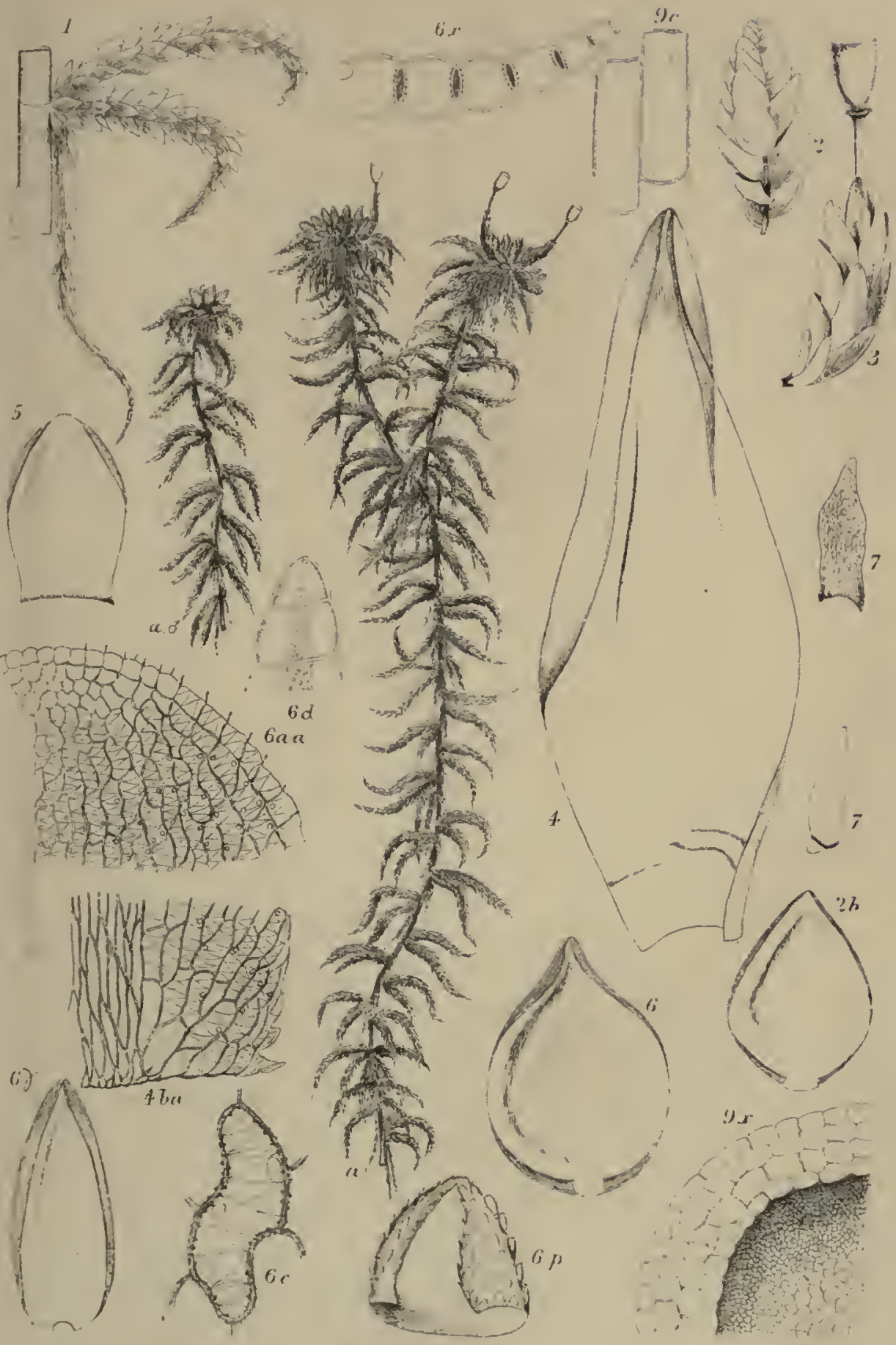



PLATE $V$. 
PLATE V.

\section{SPHAGNum Cymbifolium, Ehrh.}

Fig. a.-Female plant. FIG. $a$ §.-Upper part of male plant.

" B.-Var. squarrosulum. FIG. $\gamma$. -Var. congestum.

" I.-Part of stem with a branch fascicle.

"2.-Male inflorescence. FIG. 2b.-Bract from same.

"3.-Fruit and perichætium. FIG. 4.-Bract from same.

" 5.-Stem leaf. FIG. 5 a a.-Arcolation of apcx.

, 5 a b. - Areolation of base.

"6.-Leaf from middle of a divergent branch.

"6p.-Point of same. FIG. $6 x$. - Transverse section.

, 6c.-Areolation at middle.

"7.-Basal intermediate leaves.

" 8.-Leaf from apex of a branch. 


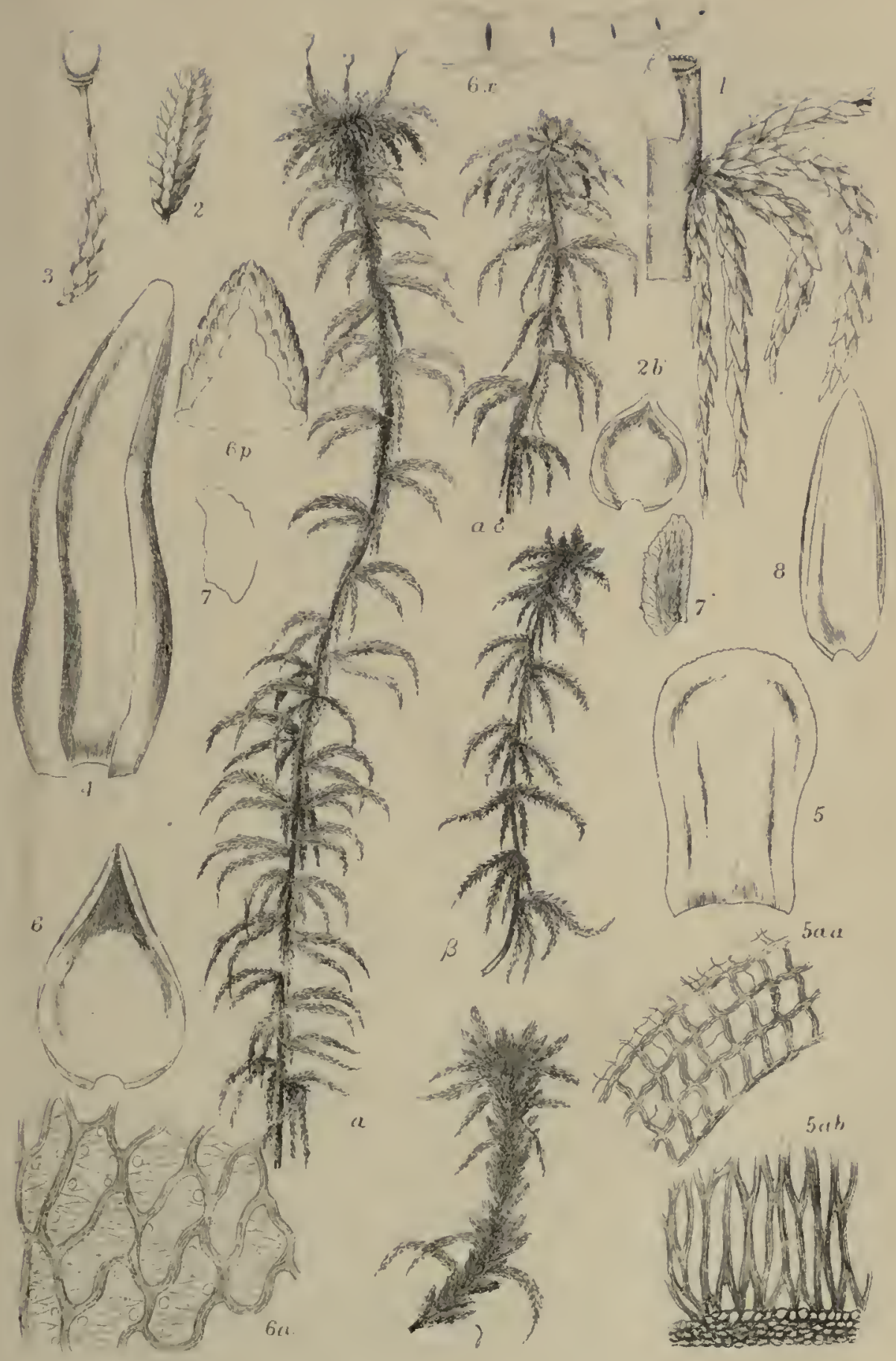

Fis adtor of 

PLATE VI. 


\section{PLATE VI.}

\section{Sphagnum tenellum, Ehrh.}

FIG. $a$.-Female plant. FIG. $a$ s.-Male plant.

" I.-Part of stem with branch fascicle.

"2.-Male inflorescence. FIG. 2b.-Bract from same.

" 3.-Fruit and perichætium. Fig. 4.-Bract from same.

"5.-Stem leaves. FiG. $5 a$. Areolation of apex. FIG. $5 a$ b.-Areolation of base.

"6.-Leaves from middle of a divergent branch. FIG. 6x.-Transverse section. Fig. 6p.-Point of same. FrG. $6 a a$. -Areolation of upper part. FIG. 6c.Cell from middle $\times 200$.

"7.-Basal intermediate leaves.

" 9x.-Part of section of stem. FIG. I0.-Branch denuded of leaves. FIG. IOx.Transverse section of same.

" $5 \beta$ and $6 \beta$.-Stem and branch leaves of var. longifolium. 


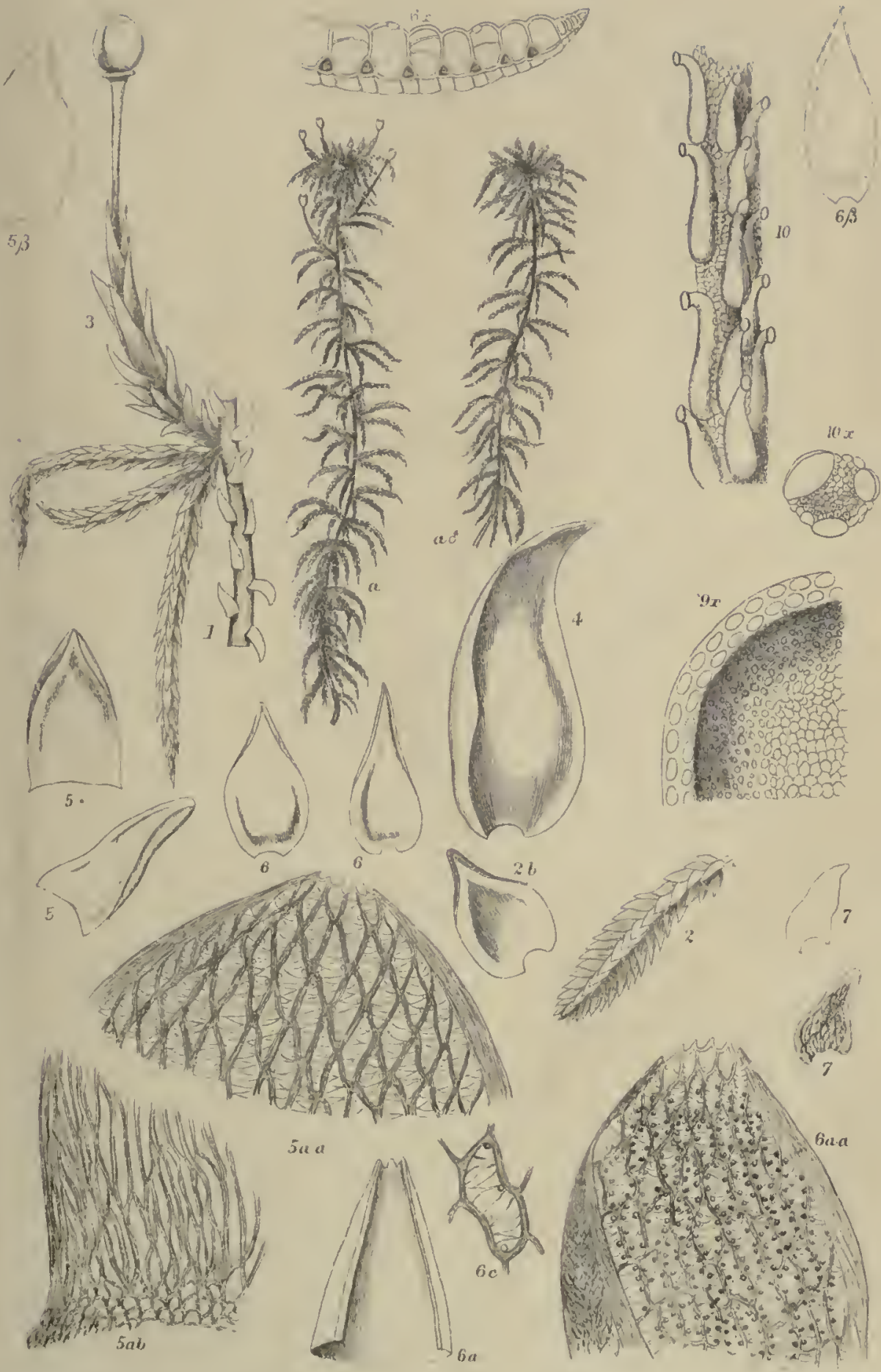





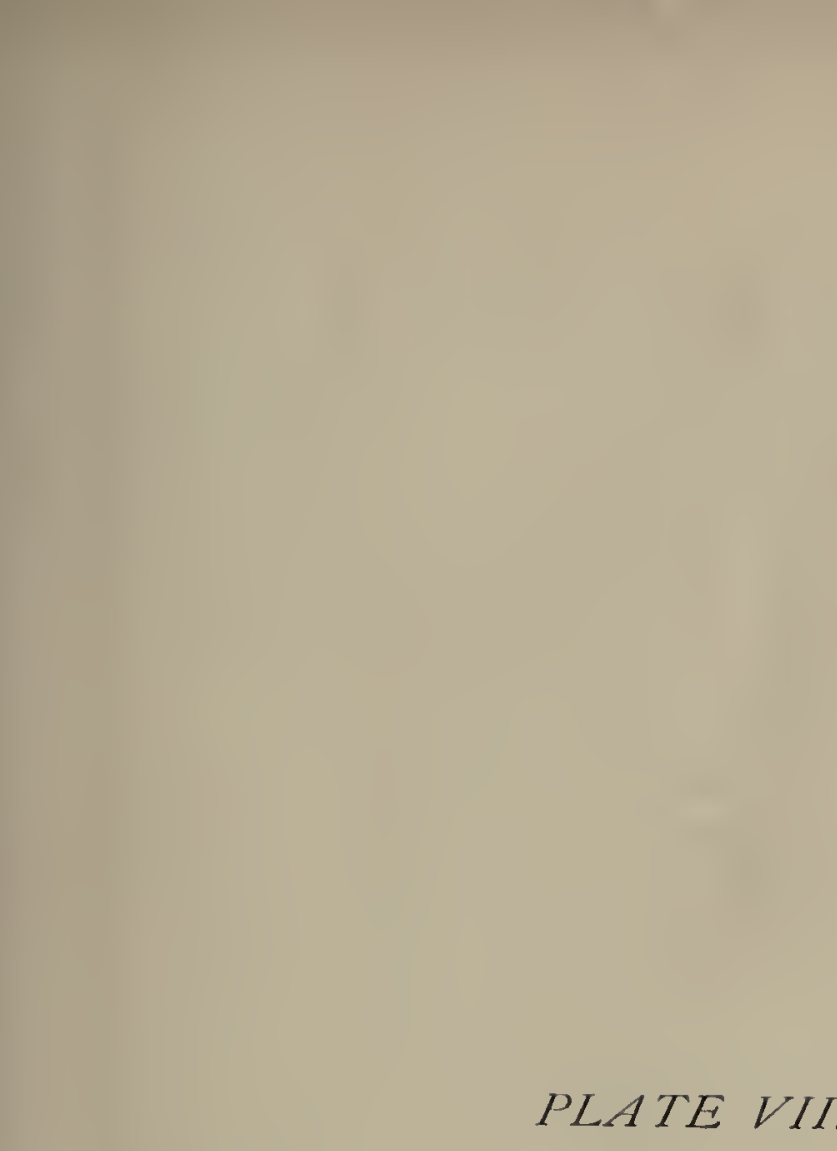

\section{PLATE VII.}




\section{PLATE VII.}

\section{Sphagnum LaRicinum, Spruce.}

FIG. $a .-F e m a l c$ plant. FiG. $a$ f .-Male plant.

"I.-Part of stem with a branch fascicle.

"2.-Male inflorescence. FIG. 2b.-Bract from same.

" 3.-Capsule and perichætium. FIG. 4.-Bract from same.

" 5.-Sten leaves. FIG. $5 a$ a.-Areolation of apex. FIG. 5 a b.-Areolation of basc of same.

"6.-Leaves from middle of a divergent branch. FIG. $6 a$ a.-Areolation of apex. FIG. $6 a b$. - Areolation of base of same. FIG. $6 p$. - Point of same. FIG. $6 c$.-Cell from middle $\times 200$. FIG. $6 x$.-Section of same.

"7.-Basal intermediate leaves.

"9x.-Part of section of stem. FIG. Io.-Branch denuded of leaves. 


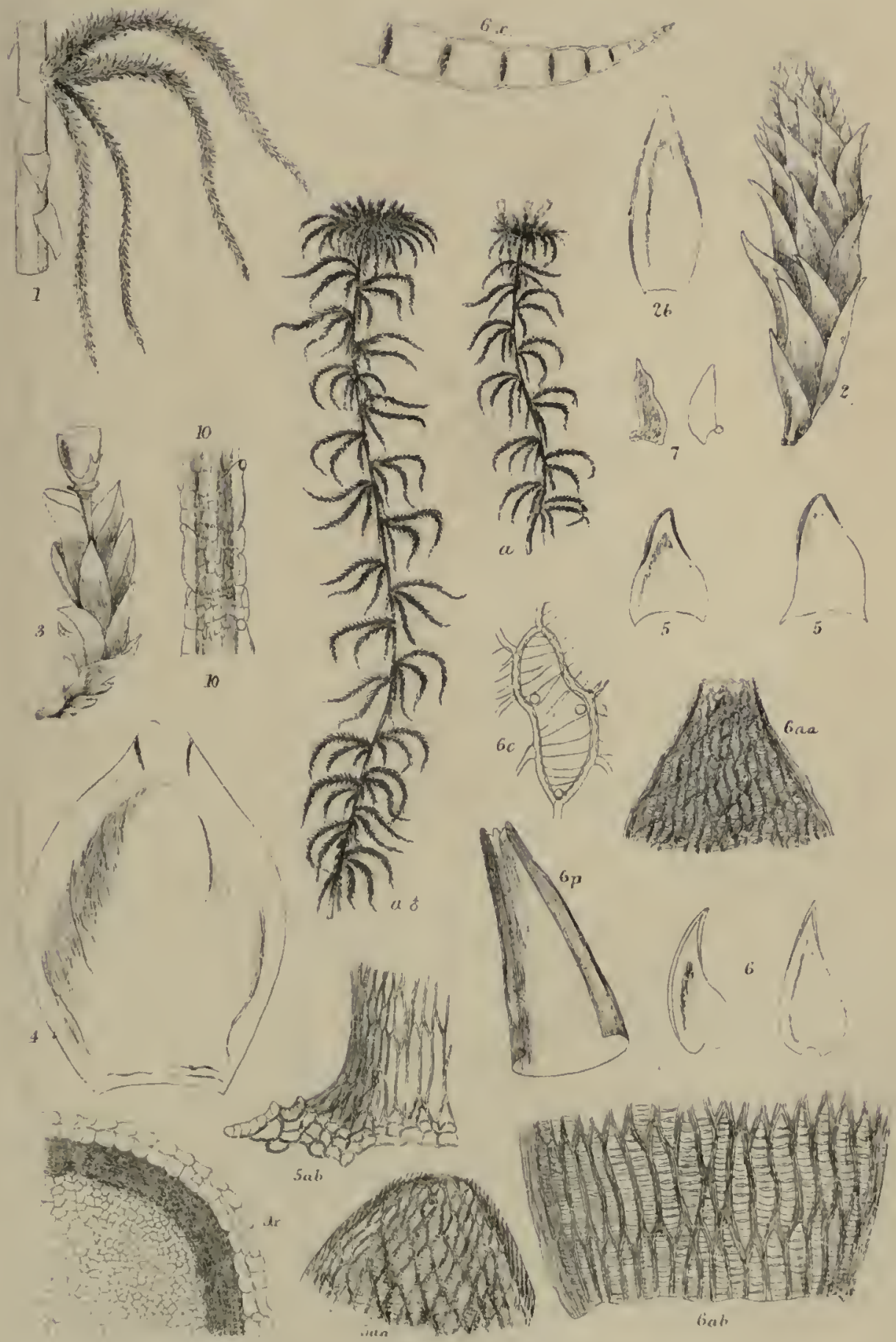



PLATE VIII. 


\section{PLATE VIII. \\ Sphagnum Laricinum Vars.}

FIG. $a_{0}-$ Fertile female plant of the typical form, from the Aland Islands ; communicated by Professor Lindberg.

" B.-Var. teretiusculum. FIG. 5.-Stem leaf. FIG. 6.-Leaves from a divergent branch.

" .-Var. platyphyllum. FIG. 5.-Sten leaf. FIG. 6.-Leaves from a divergent branch.

" 8.-Var. cyclophyllum. FIG. 5.-Stem leaves. FIG. 6.-Branch leaf. 

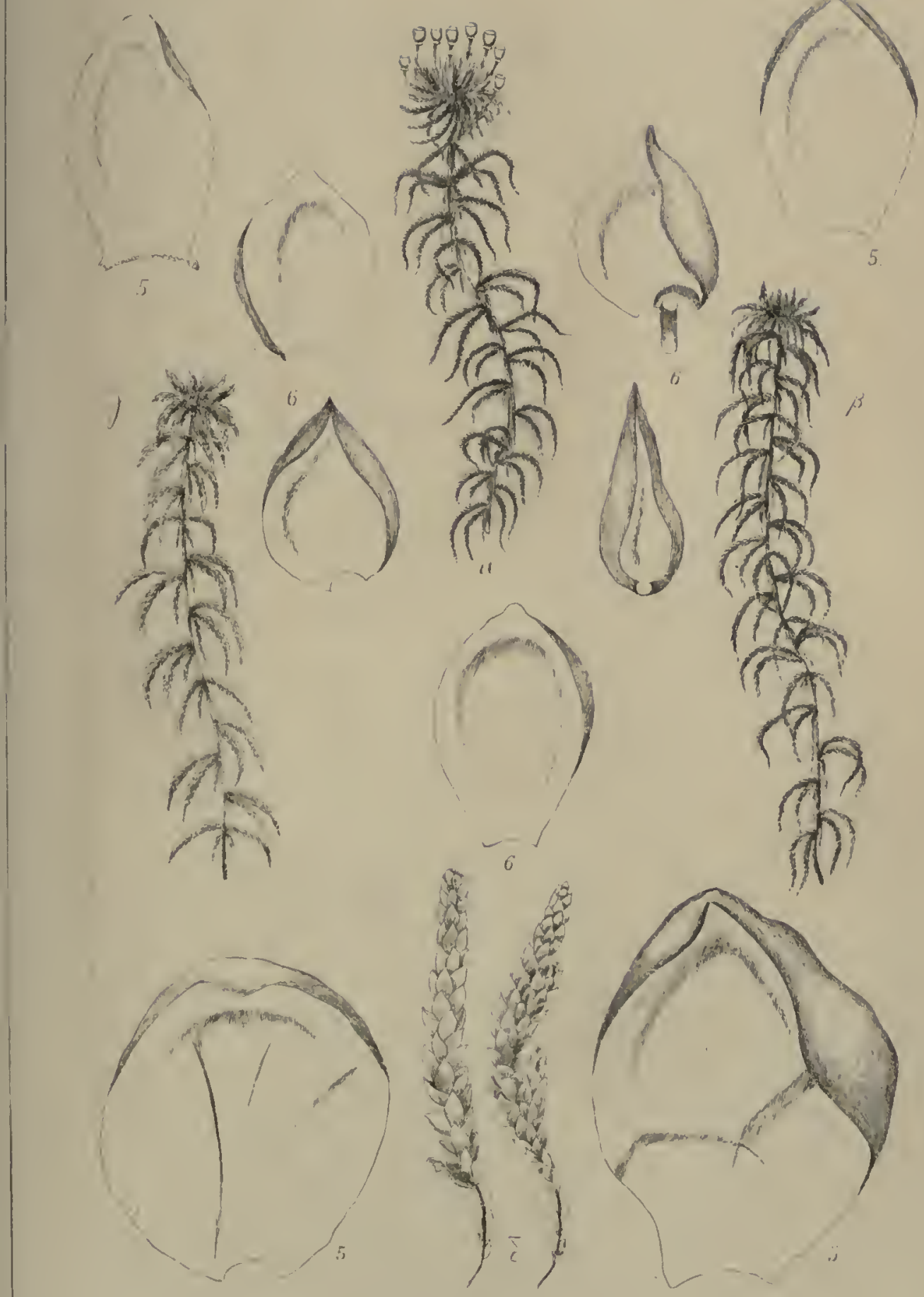

PLATE IX.

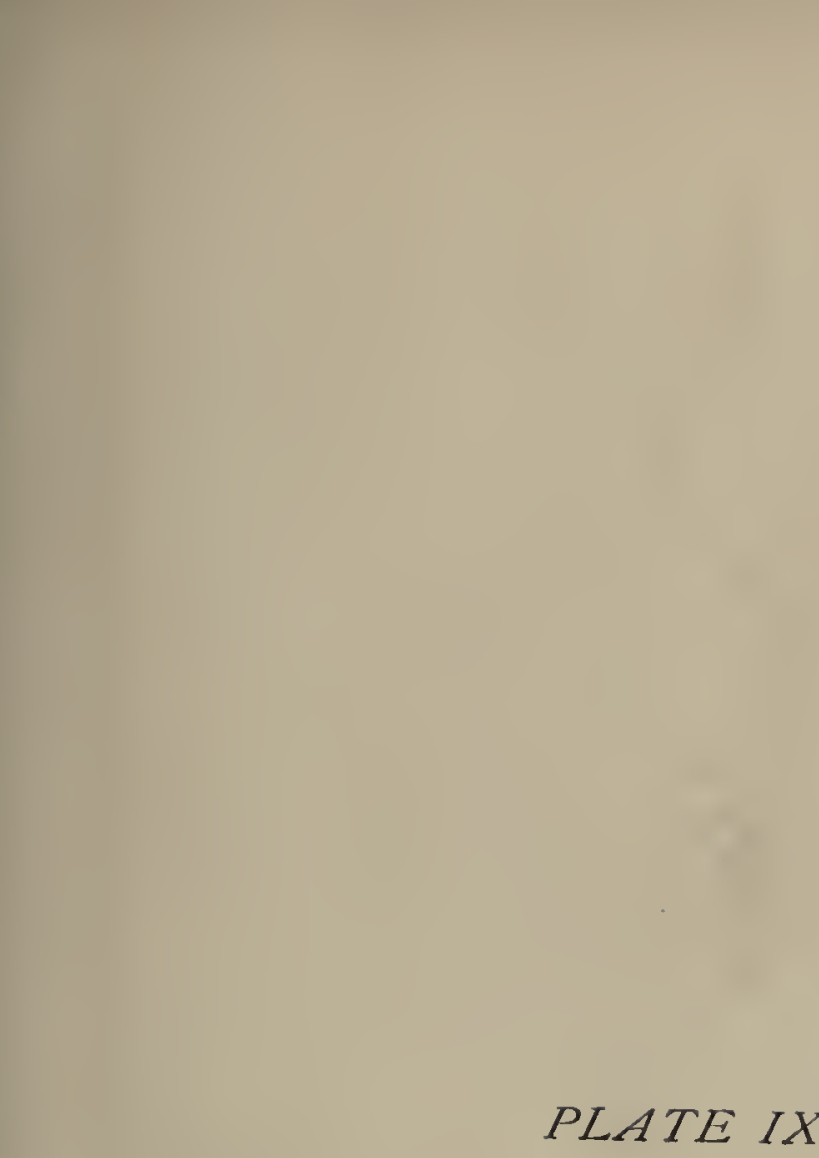


PLATE IX.

Sphagnum Subsecundum, Nees v. Esenb.

Fig. a.-Female plant. Fig. $a$ f. - Male plant.

"1.-Part of stem with a branch fascicle.

"2.-Male infiorescence. FIG. 26.-Bract from same.

" 3.-Fruit and perichætium. FIG. 4.-Bract from same.

" 5.-Stem leaf. FIG. $5 a$ a.-Areolation of apex. FiG. $5 a b$.-Areolation of base.

"6.-Leaf from middle of a divergent branch. FIG. 6x.-Transverse section. Fig. 6p.-Point of same. Fig. $6 a a$.-Areolation of apex. Fig. $6 a$ b.-Ditto of base. Fig. $6 c$-Cell from middle $\times 200$.

"7.-Basal intermediate leaves. FIG. $9 x$. - Part of section of stem. 

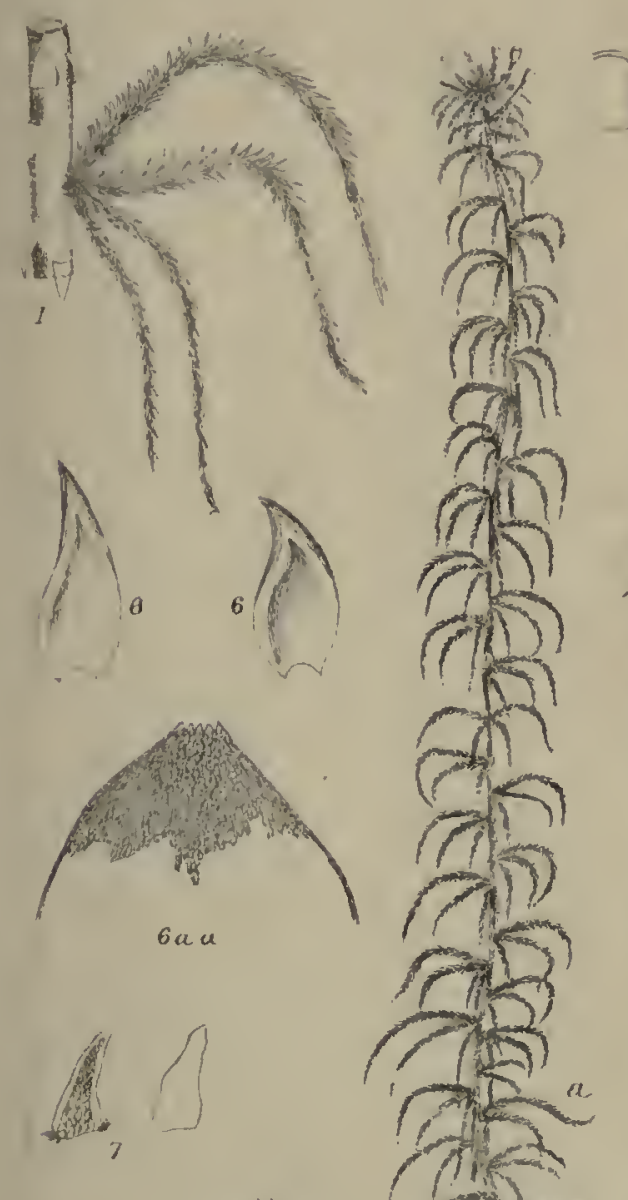

711111
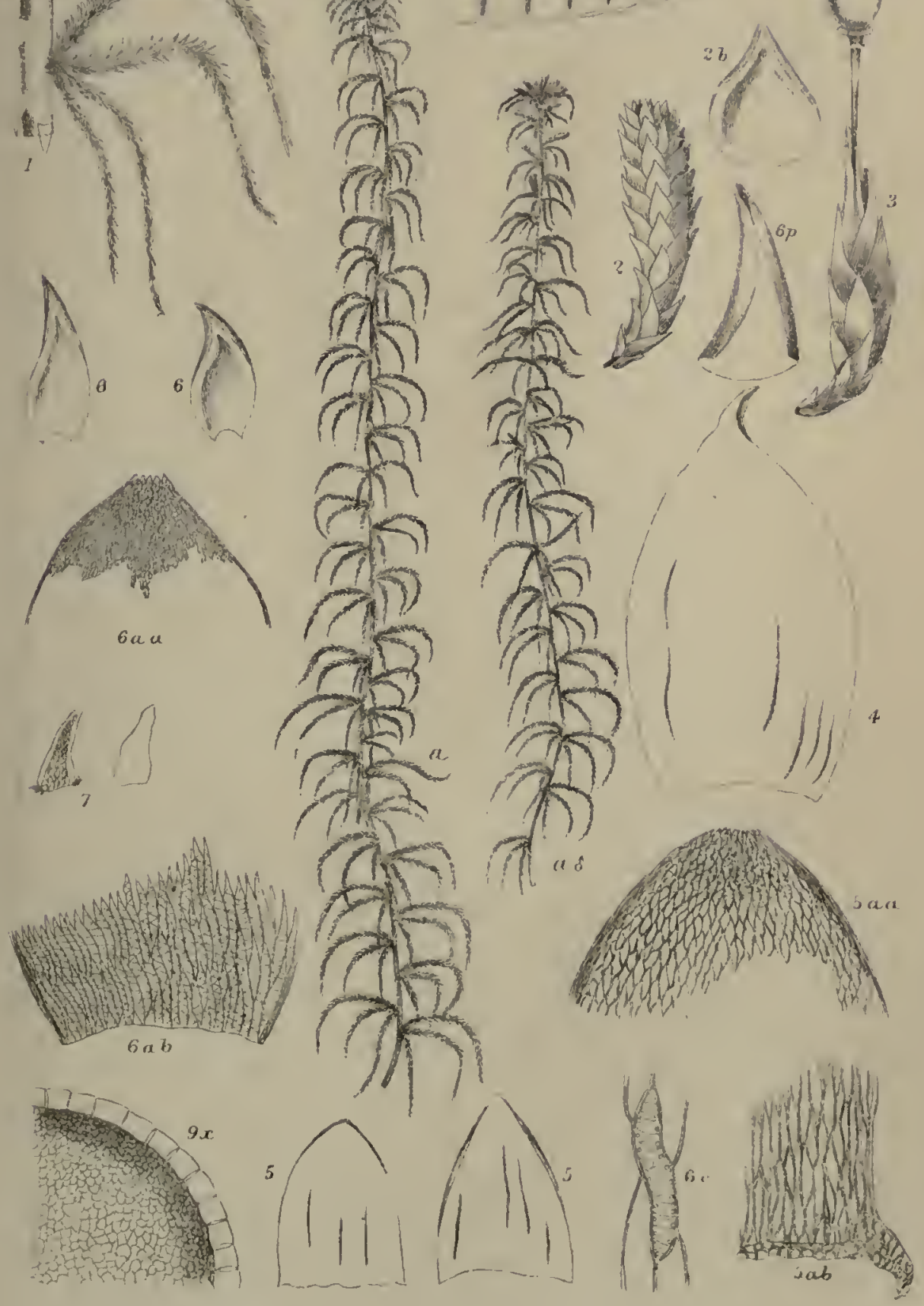

PLATE X.
.

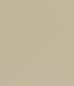

.

\section{.

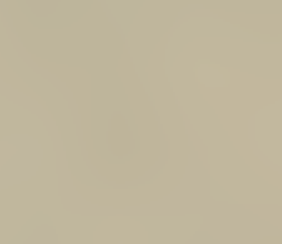

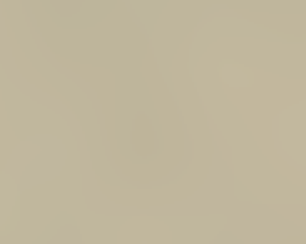

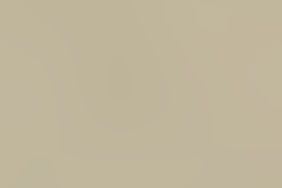

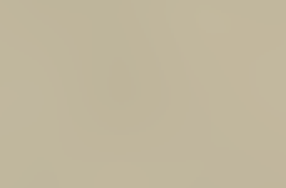

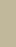




\section{PLATE X.}

\section{Sphagnum subsecundum Vars.}

Fig. B.-Var. contortum. FIG. 5.-Stem leaf. FIG. 6.-Branch leaf.

" $\gamma$-Var. auriculatum. FIG. 5.-Stem leaf. FIG. 5ab.-Basal wing of same $\times 200$. Fig. 6.-Branch leaf.

"8.-Var. obesum. Fig. 6.-Branch leaf. 


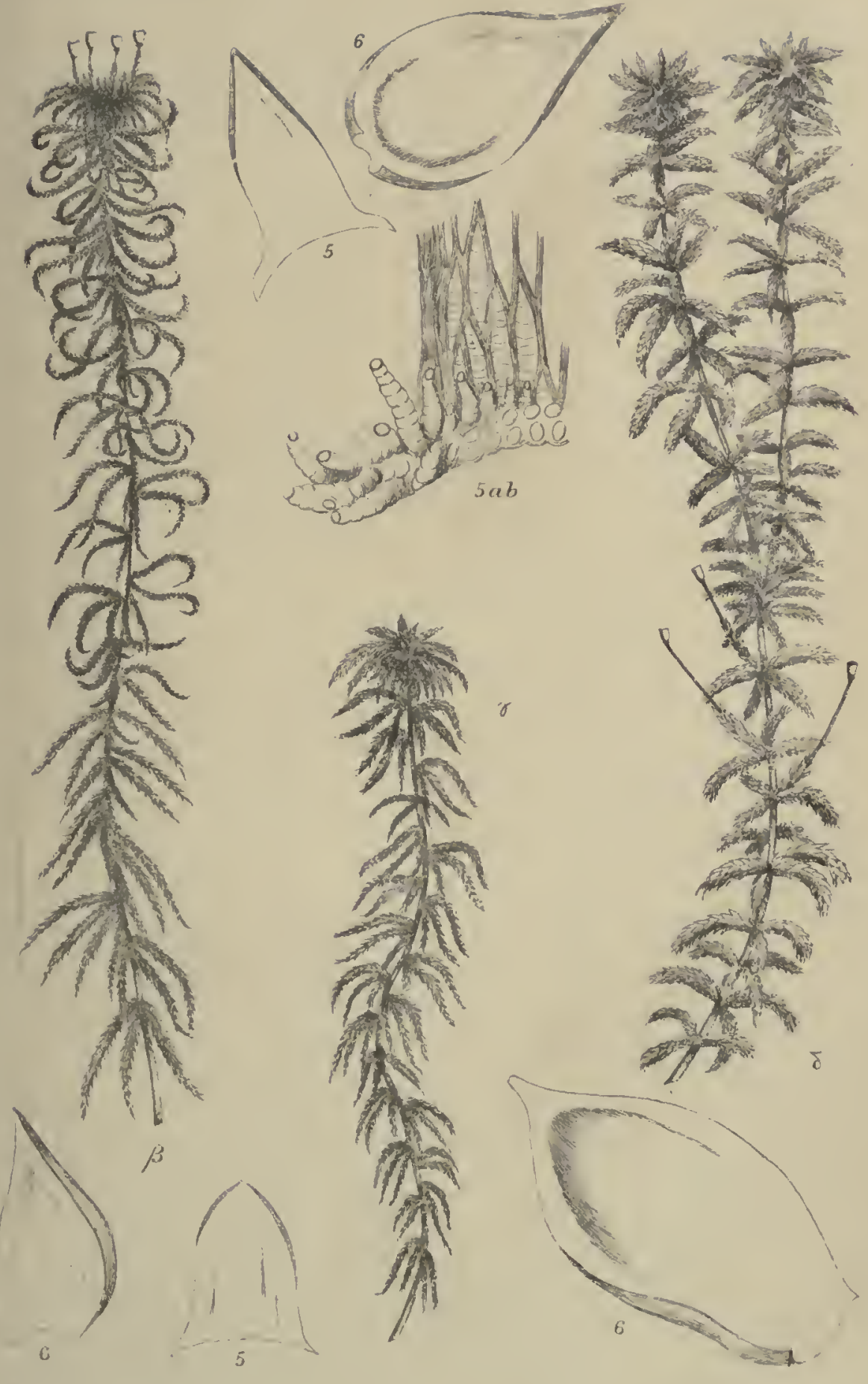



PLATE XI. 


\section{PLATE XI.}

\section{SPHAGNUM ÅNGSTrömir, Hartm.}

FIG. a.-Female plant. FIG. $a$ §.-Male plant.

"1.-Part of stem and branch fascicle.

"2.-Male inflorescence.

" 3.-Fruit and perichretium. FIG. 4.-Bract from same.

"4p.-Point of an inner bract.

" 5.-Stem leaves. Fig. 5 a a.-Areolation of apex of same.

"6.-Leaves from a divergent branch. FIG. $6 p .-$ Point of same.

" 6aa.-Areolation of same. FrG. 6x.-Section.

"6c.-Cell from mịddle $\times 200$.

"7.-Basal intermediate leaves.

" 8.-Leaf from a pendent branch.

" $9 x .-$ Transverse section of stem.

" 10.-Part of a branch denuded of leaves. 


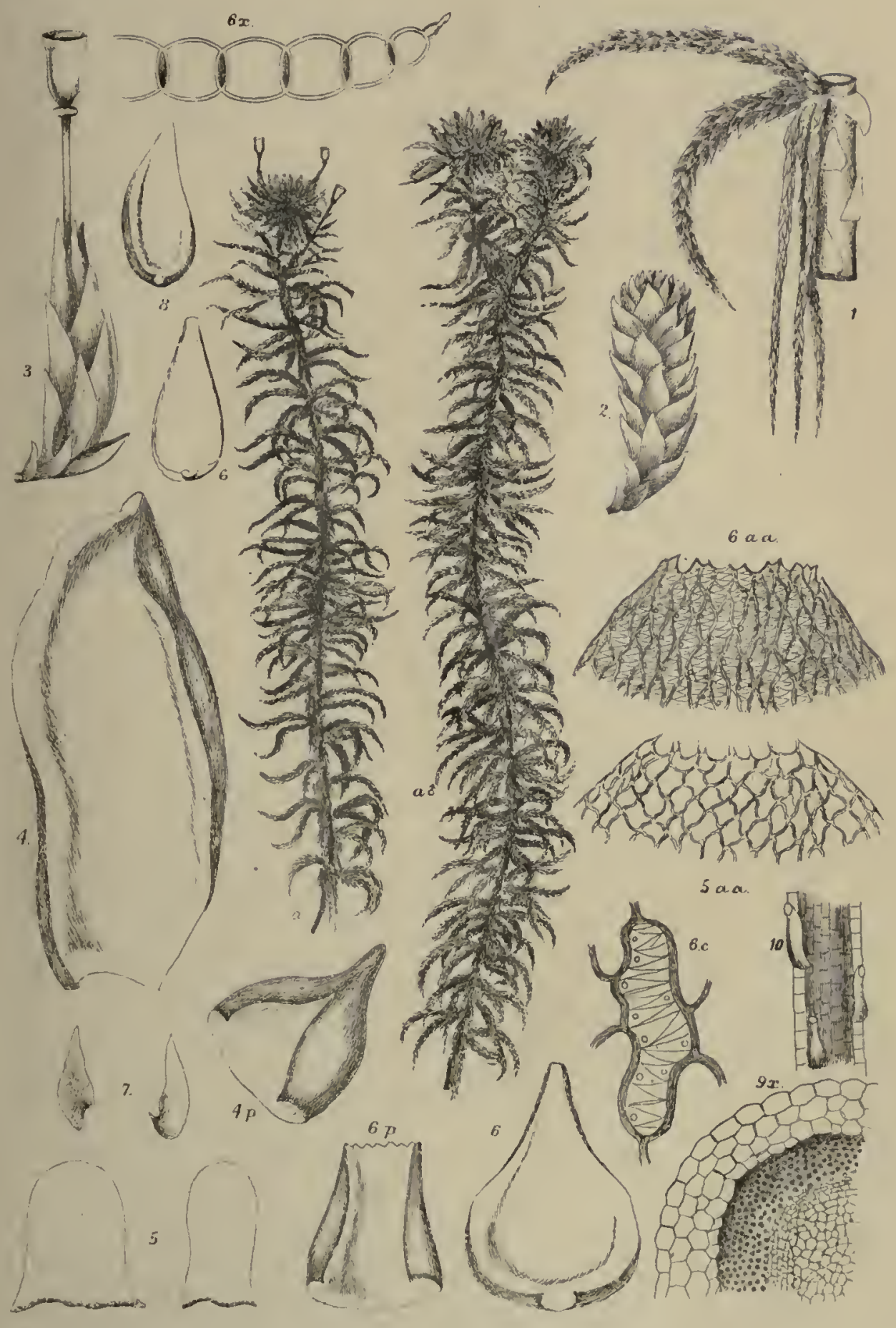

WVíasquét. 

PLATE XII.

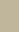


PLATE XII.

SPHAGNUM MOLle, Var. $\beta$.

FIG. a.-Fertile plant from Darnholm.

"1.-Part of stem with branch fascicle and fruit.

" 2.-Male inflorescence. FIG. 4'.-Perichrtial bract of type from Sullivant's figure.

" 4.-Perichrtial bract from British plant. FIG. 4p.-Point of same.

" 5.-Stem leaves. FIG. $5 a a .-$ Areolation of apex of same. Fig. $5 a b$.-Ditto of basal wing.

"6.-Leaf from middle of a divergent branch. FIG. $6 p$. - Point of same. FIG. 6x. -Transverse section. FIG. 6c.-Cell from middle $\times 200$.

"7.-Basal intermediate leaf. FIG. 9x,-Part of section of stem. FIG. 10.-Part of a branch denuded of leaves. 


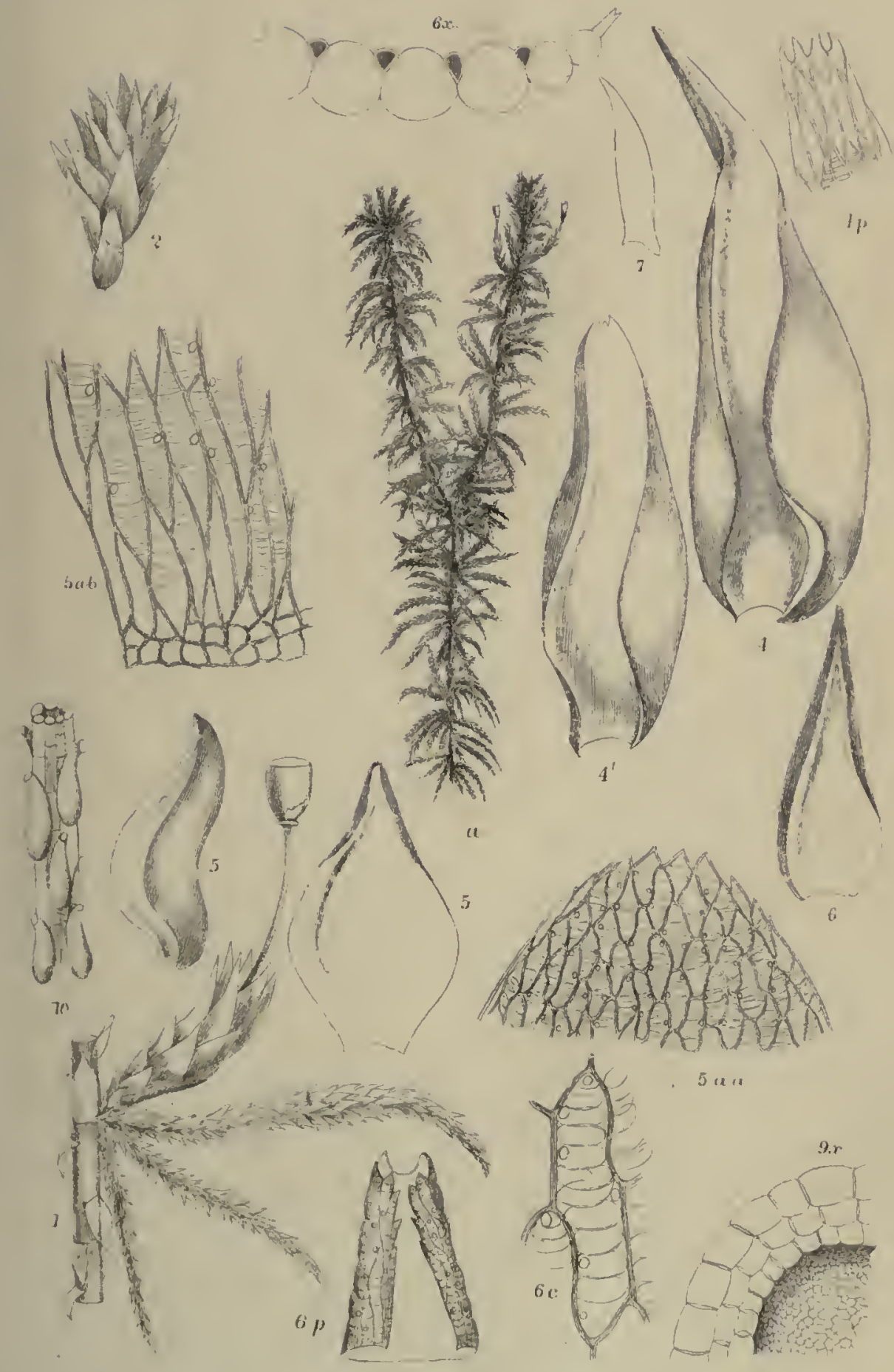



PLATE XIII. 


\section{PLATE XIII.}

Sphagnum Rigidum, Nees v. Esenb.

FIG. a. - Fertile plant. FIG. I. - Part of stem with a branch fascicle.

" 3.-Fruit and perichætium. FIG. 4.-Bract from same.

5.- Stem leaves. FIG. 5 a a.-Areolation of apex of same.

"6.-Leaves from middle of a divergent branch.

"6aa.-Areolation of apex of same expanded. FiG. 6x. - Transverse section. Fig. 6p.-Point of same. Fig. 6c.-Cell from middle $\times 200$. FIG. 6r.Reticulation at back $\times 400$.

"7.-Basal intermediate leaf.

" 8.- Leaf from a pendent branch with an antheridium.

" 9.x.-Part of section of stem. Fig. 10.-Part of a branch denuded of leaves.

" B.-Var. compactum.

" $\gamma$-Var. squarrosum. 


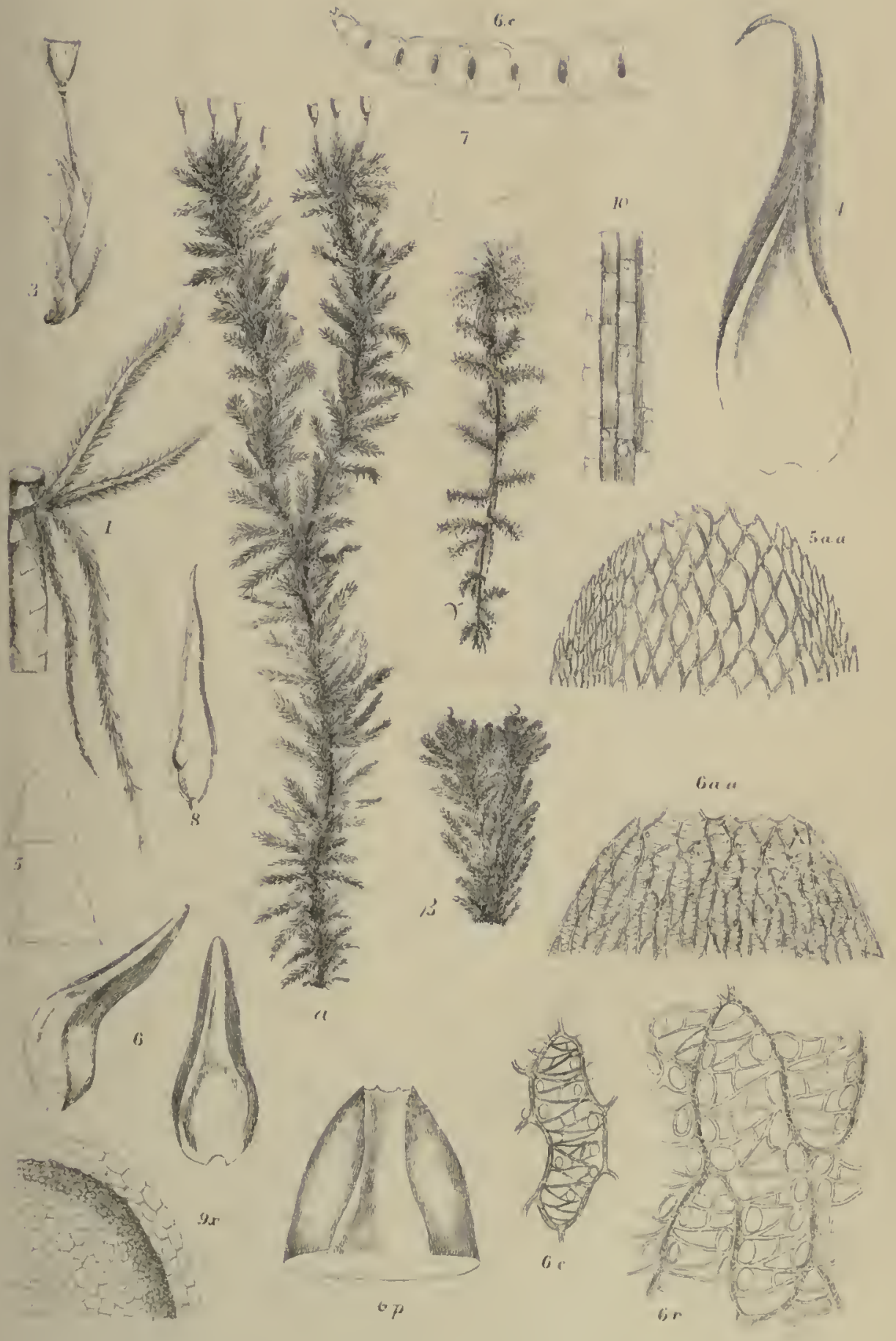



PLATE XIV. 


\section{PLATE XIV.}

\section{Sphagnum squarrosum, Persoon.}

FIG. a.-Fertile plant.

"1.-Part of stem with a branch fascicle and male inflorescence.

" 3.-Pcrichætium and fruit. FIG. 4.-Upper bract from same.

" 5.-Stem leaves. FIG. 5 a a.-Areolation of apex of same.

"6.-Leaves from a divergent branch. FIG. 6x.-Section.

"6p.-Point of same. Fig. 6c.-Cells from middle $\times 200$.

"7.-Basal intermediate leaf. FIG. $9 x$.-Part of section of stem.

"10.-Part of a branch denuded of leaves. 


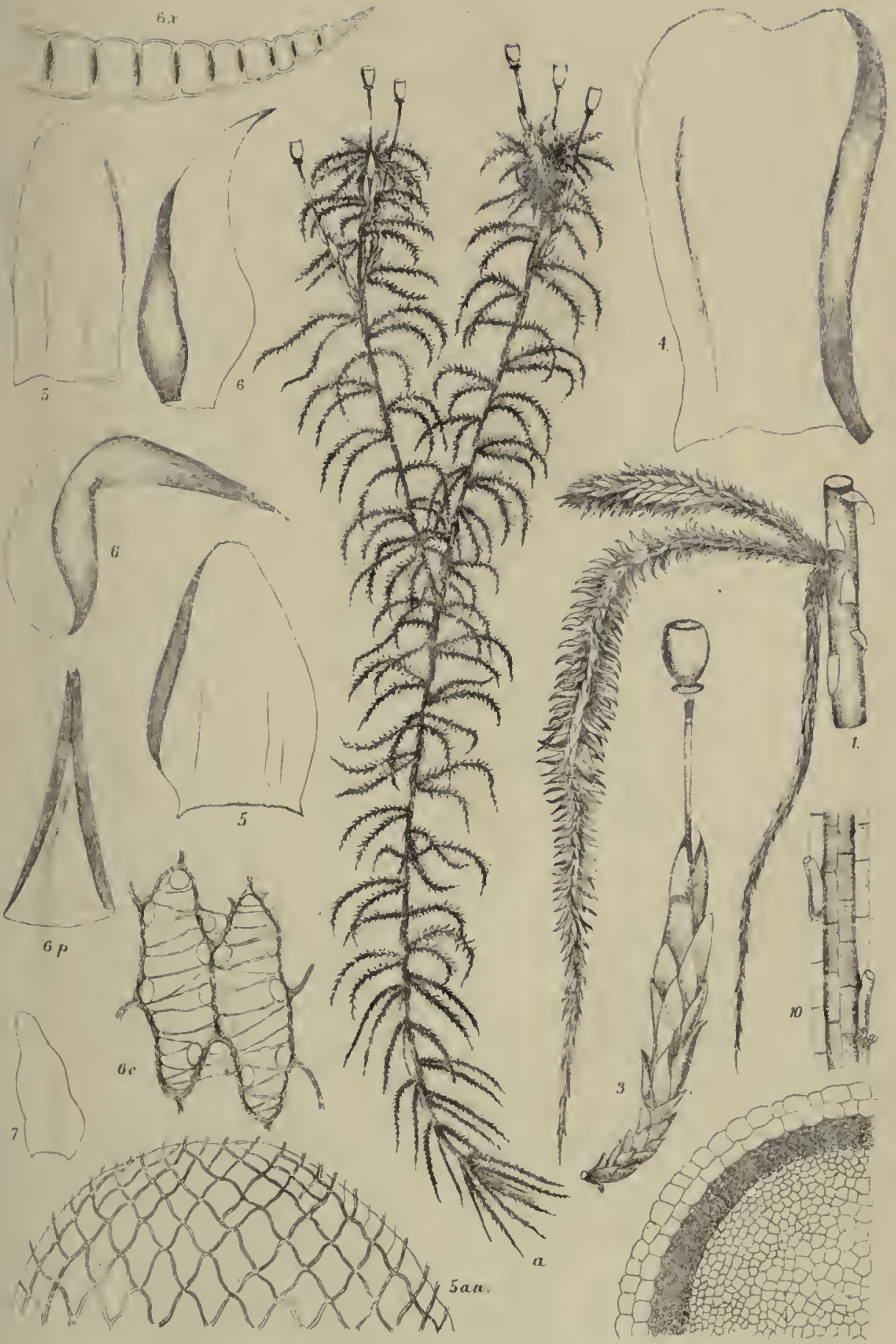



PLATE XV. 


\section{PLATE XV.}

Sphagnum squarrosum, var. teres.

FIG. a. -Female plant. FIG. $a$ \$.-Male plant.

"I.-Part of stem and a branch fascicle.

" 2.-Male inflorescence. FIG. 2b.-Bract from same with an antheridium.

" 3.-Perichætium and fruit. F1G. 4.-Upper bract from same.

" 5.-Stem leaf. Fig. 5 a a.-Areolation of apex of same.

"6.-Leaves from a divergent branch. FIG. 6x.-Section. FIG. 6p.-Point of same. FiG. 6c.-Cells from middle $\times 200$.

"7.-Basal intermediate leaf. FIG. 8.-Leaf from a pendent branch. FIG. 9x.-Part of section of sten.

"10.-Part of a branch denuded of leaves. 


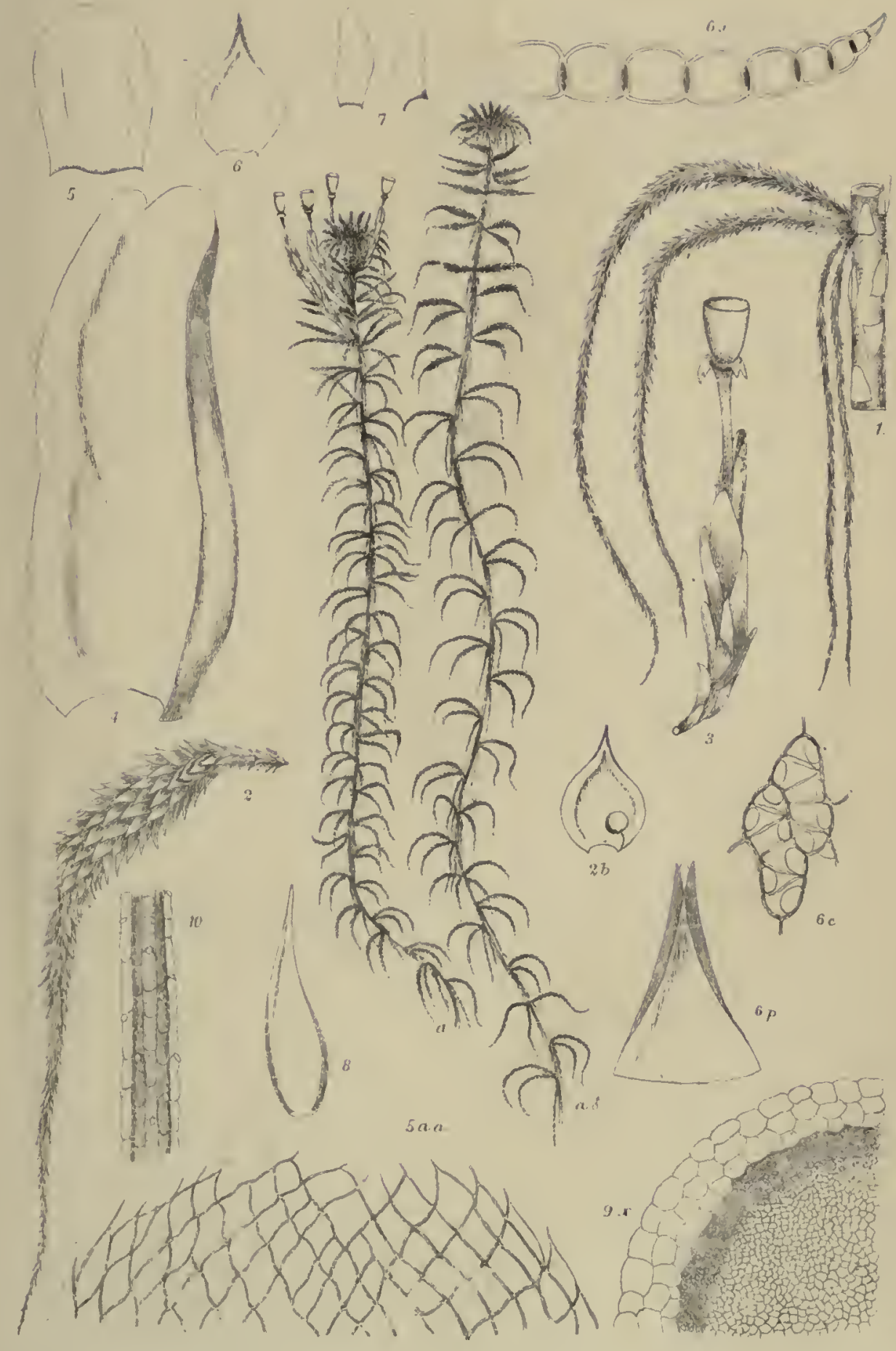



PLATE XVI. 


\section{PLATE XVI.}

\section{SPHAGNUm FIMBRIATUM, Wilson.}

FIG. a. - Fertile plant. FIG. I.-Part of stem with a branch fascicle.

"2.-Male inflorescence. FIG. 2b.-Bract from same.

" 3.-Fruit and perichætium. FIC. 4.-Upper bract from same.

" 5.-Stem leaf. FIG. 5 a a.-Areolation of part of apex of same.

"6.-Leaf from middle of a divergent branch. FiG. 6p.-Point of same. FIG.6c.Cells from middle $\times 200$. FIG. $6 x$, - Transverse section.

"7.-Basal intermediate leaves.

" 8.-Leaf from a pendent branch. FIG. $9 x$-Part of section of stem. FIG. 9c.Outer cuticular cells.

"10.-Part of a branch denuded of leaves. 


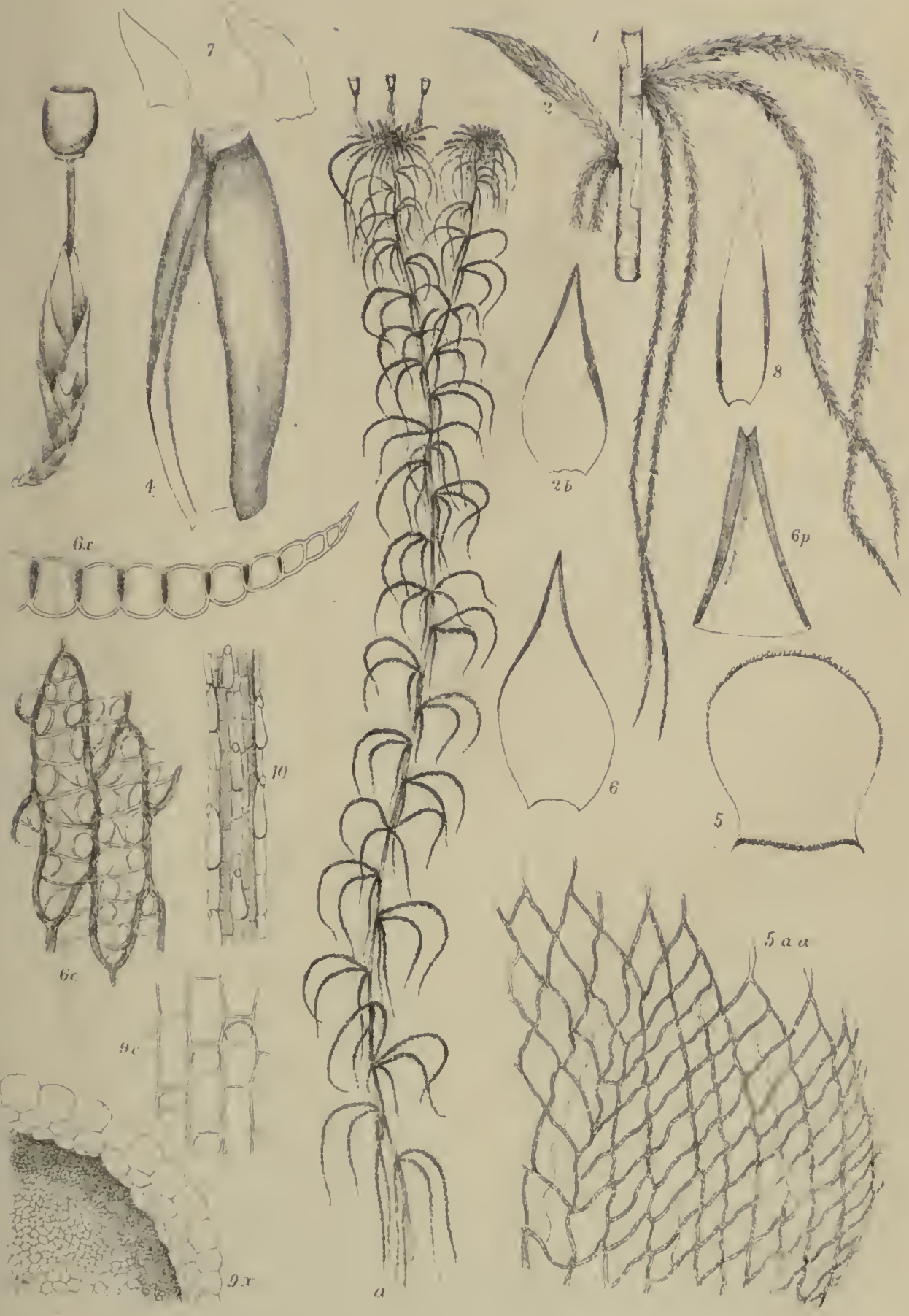



PLATE XVII. 


\section{PLATE XVII.}

\section{SPHAGNUM STRICTUM, Lindb.}

FIG. a.-Female plant. Fig. \$.-Male plant.

$"$ 1. - Part of stem with a branch fascicle.

"2b.-Bract from male inflorescence with antheridium.

"3.-Fruit and perichrtium. FIG. 40-Bract from same.

" 4a.-Apex of same expanded. FiG. 5.-Stem leaves.

" 5 a a.-Areolation of apex of same.

"6.-Leaves from a divergent branch. FIG. 6p.-Point of same.

"6c.-Cells from middle $\times 200$.

" 6x.-Transverse section.

"7.-Basal intermediate leaf.

"9x.-Part of section of stem.

" so.-Part of a branch denuded of leaves. 


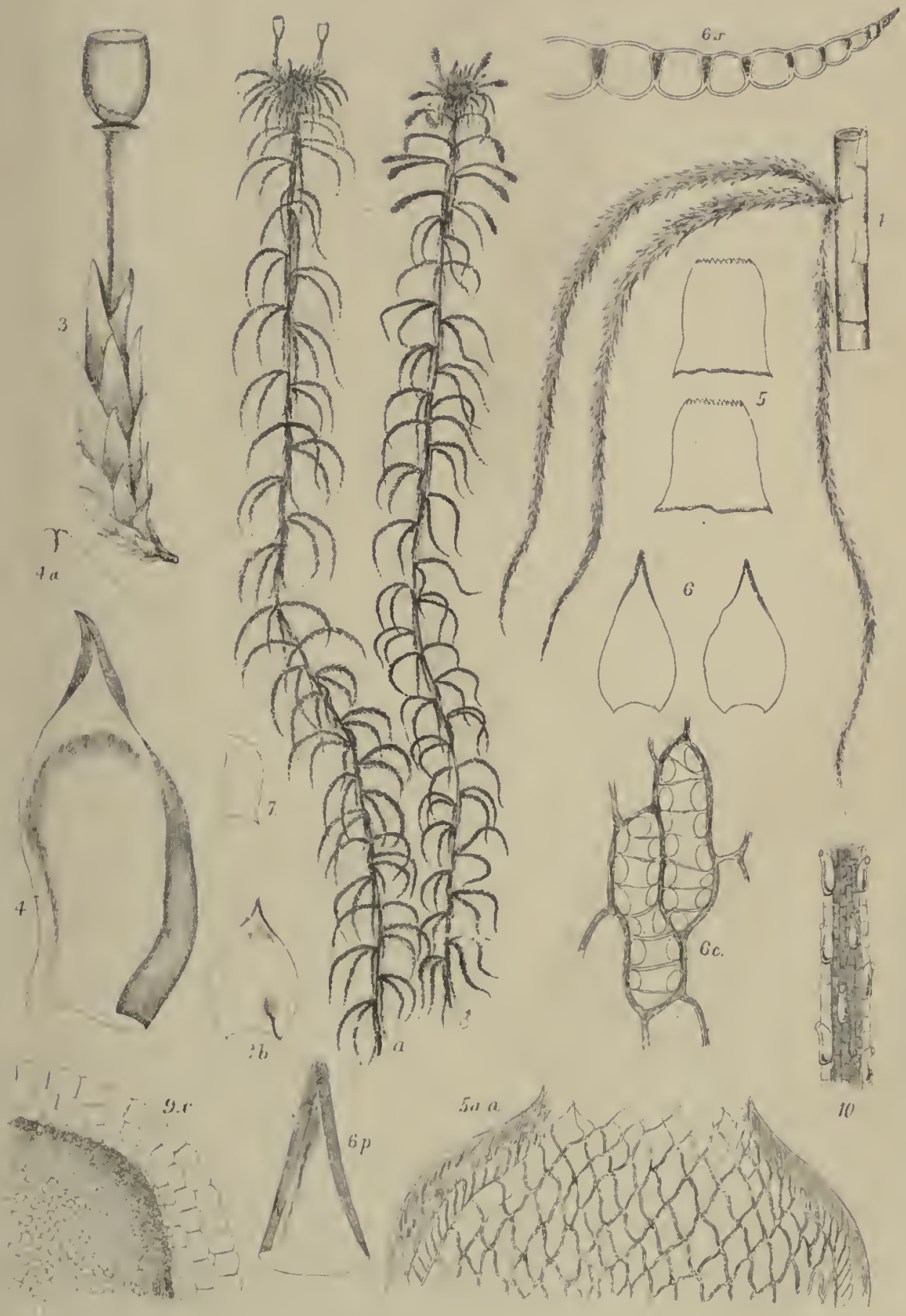



PLATE XVIII. 


\section{PLATE XVIII.}

\section{Sphagnum acUtifolium, Ehrhart.}

FIG. a.-Plant of the typical form.

"I.-Part of stem with a branch fascicle.

"2.-Male inflorescence. FiG. 2b.-Bract and antheridium from same.

"3.-Fruit and perichretium. FIG. 4.-Bract from same.

" 5.-Stem leaves. FIG. 5 a a.-Areolation of apex of same.

"6.-Leaves from middle of a divergent branch.

" $6 a b$. -Areolation of base. FiG. $6 x$. -Transverse section.

"6p.-Point of same. FIG. $6 c$. -Cell from middle $\times 200$.

"7.-Basal intermediate leaves. FIG. 8.-Leaf from a pendent branch.

"9x.-Part of section of stem.

"10.-Part of a branch denuded of leaves. 

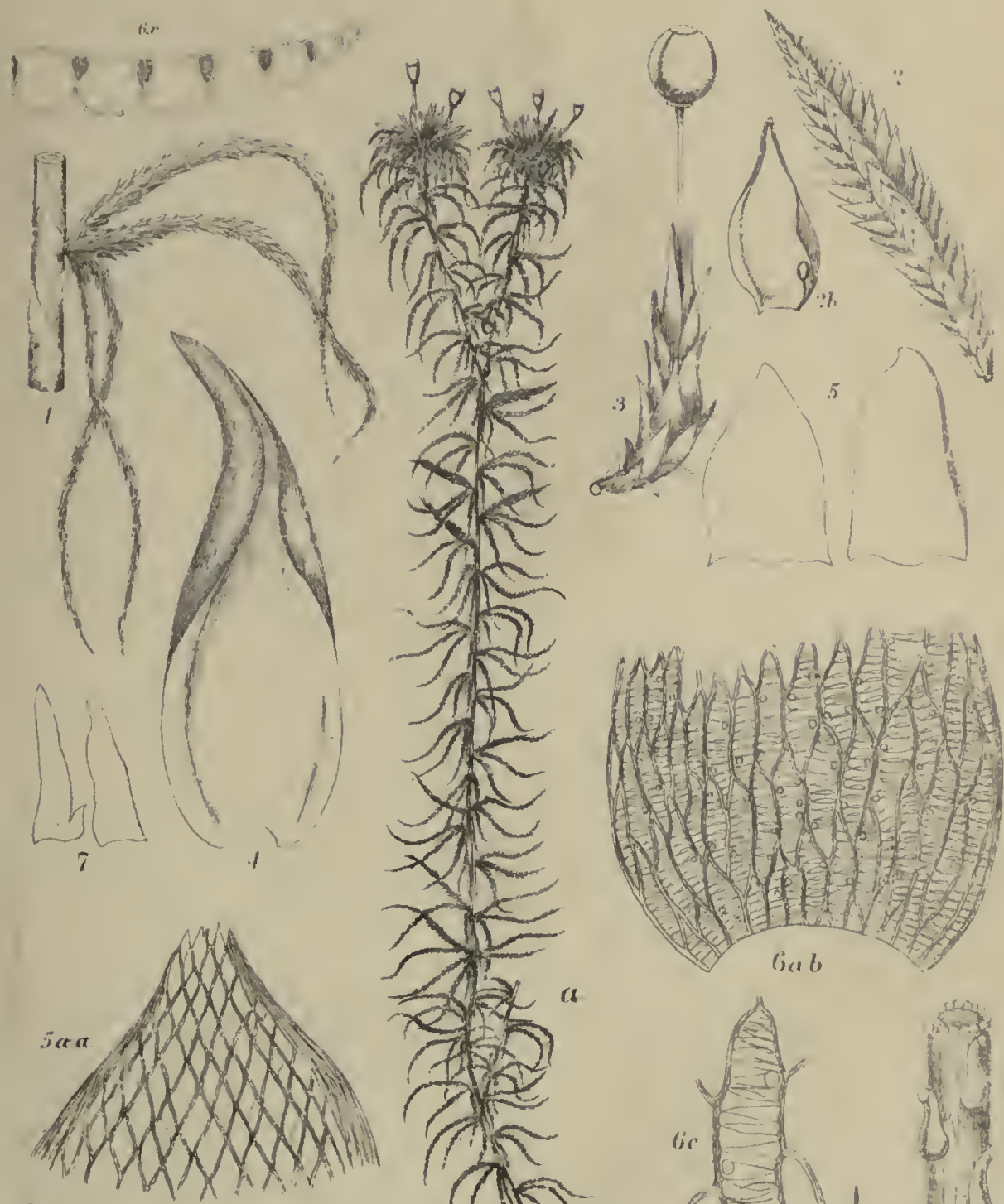

PLATE XIX. 


\section{PLATE XIX.}

SPhagNUm ACUTIFOLIUM, var, rubellum.

Fig. $a$.-Female plant. Fig. $a$ .-Male plant.

" I.-Part of stem with a branch fascicle.

"2.-Male inflorescence. FIG. 2b.-Bract from same.

" 3.-Fruit and perichrtium. FIG. 4.-Bract from same.

" 5.-Stem leaves. FIG. $5 a$ a.-Areolation of apex. FIG. 5ab.-Ditto of base.

$"$ 6.-Leaves from middle of a divergent branch. Fig. 6x-Transverse section. FIG. $6 p$.-Point of same. Fig. 6aa.-Areolation of apex. Fig.6ab.Areolation of base. Fig. $6 c_{0}$ - -Single cell from middle $\times 200$.

"7.-Basal intermediate leaves.

"8.--Leaf from a pendent branch.

" 9x.-Part of section of stem.

"10.-Branch denuded of leaves. 


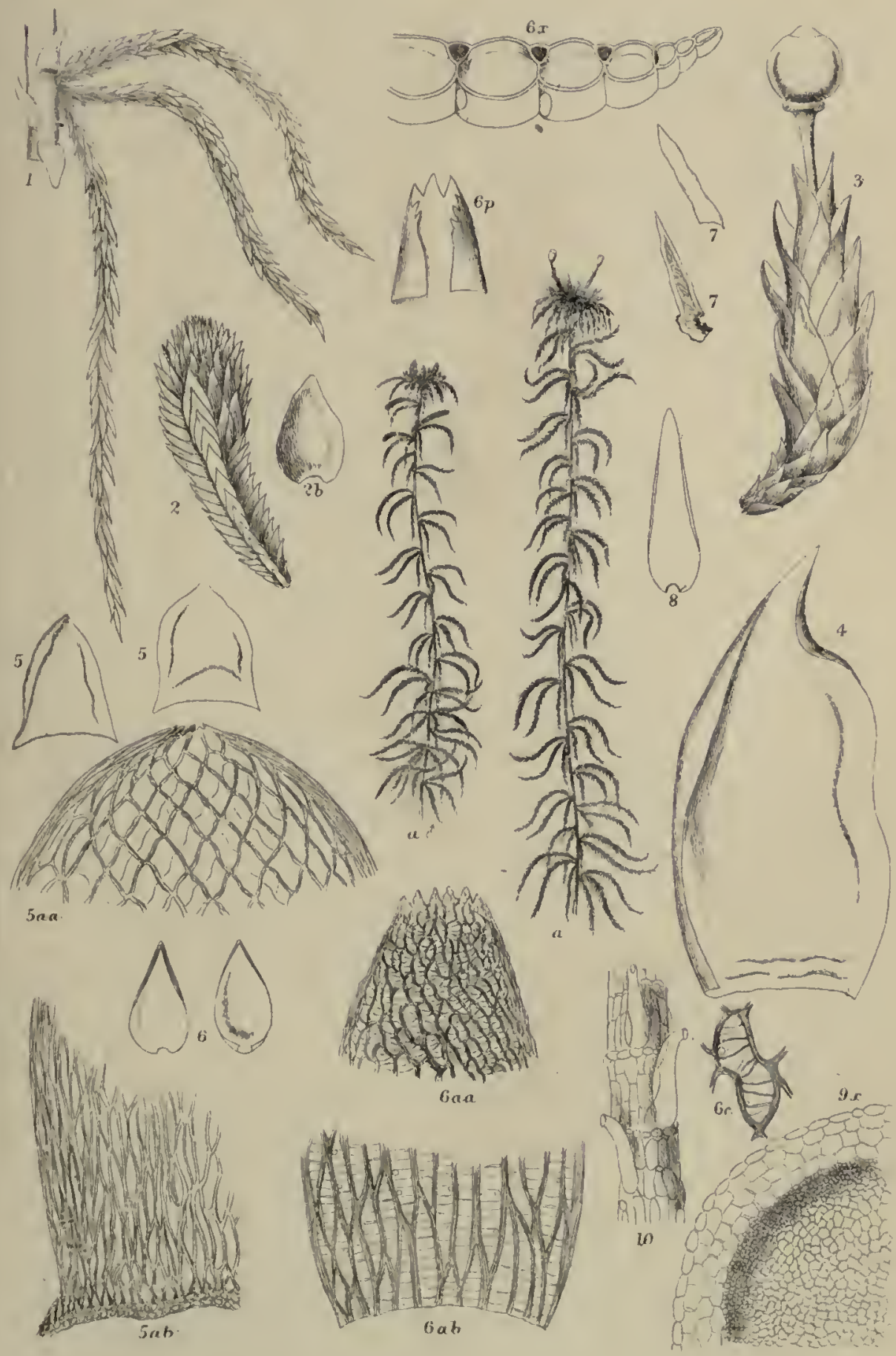



PLATE $X X$. 


\section{PLATE XX.}

SPHaGnum acutifolium. Vars.

FIG. $\beta .-$ Var. deflexum.
". - " purpurezm.
" є.- " tenue.
" ¿.- " fuscum.
" $\lambda_{0}-$ - luridum.

" 5.-Stem leaves. FIG. 6.-Branch leaves. 

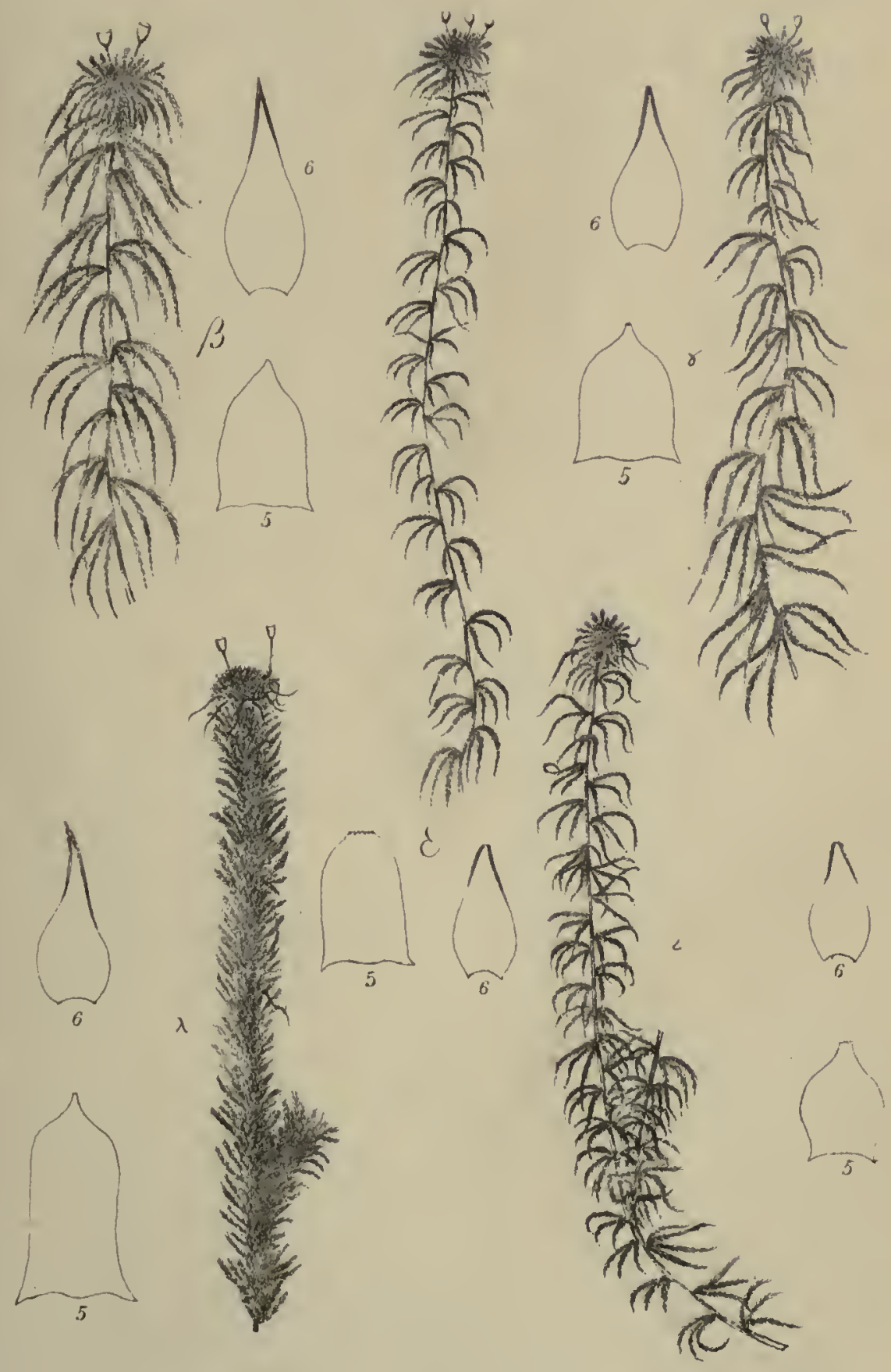
. 


\section{PLATE XXI.}

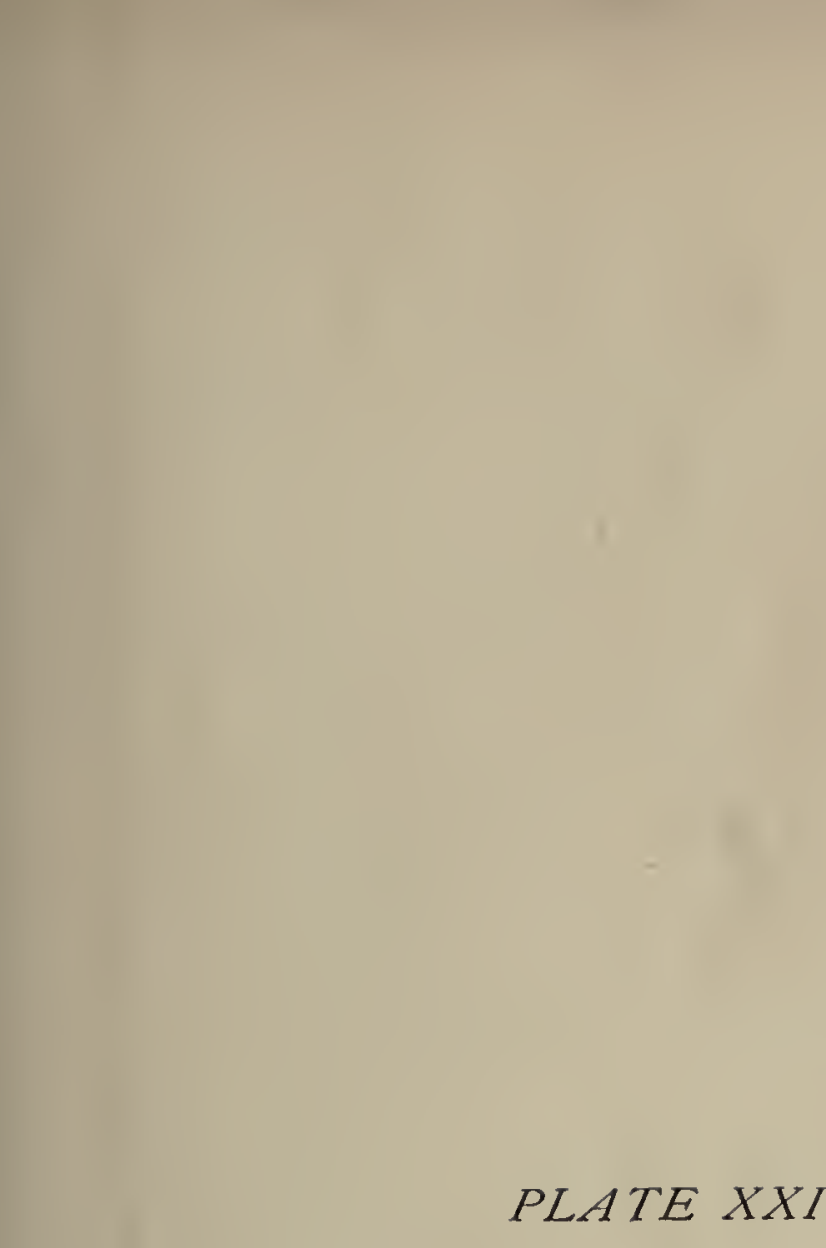


PLATE XXI.

SPhagnum acutifolium Vars.

FIG. 5.-Var. quinquefarium.

0._, elegans.

$" \kappa_{0}-$, arctum.

" $\mu_{0}-$ " late-virens.

" 5.-Stem leaves. FIG. 6.-Branch leaves. 


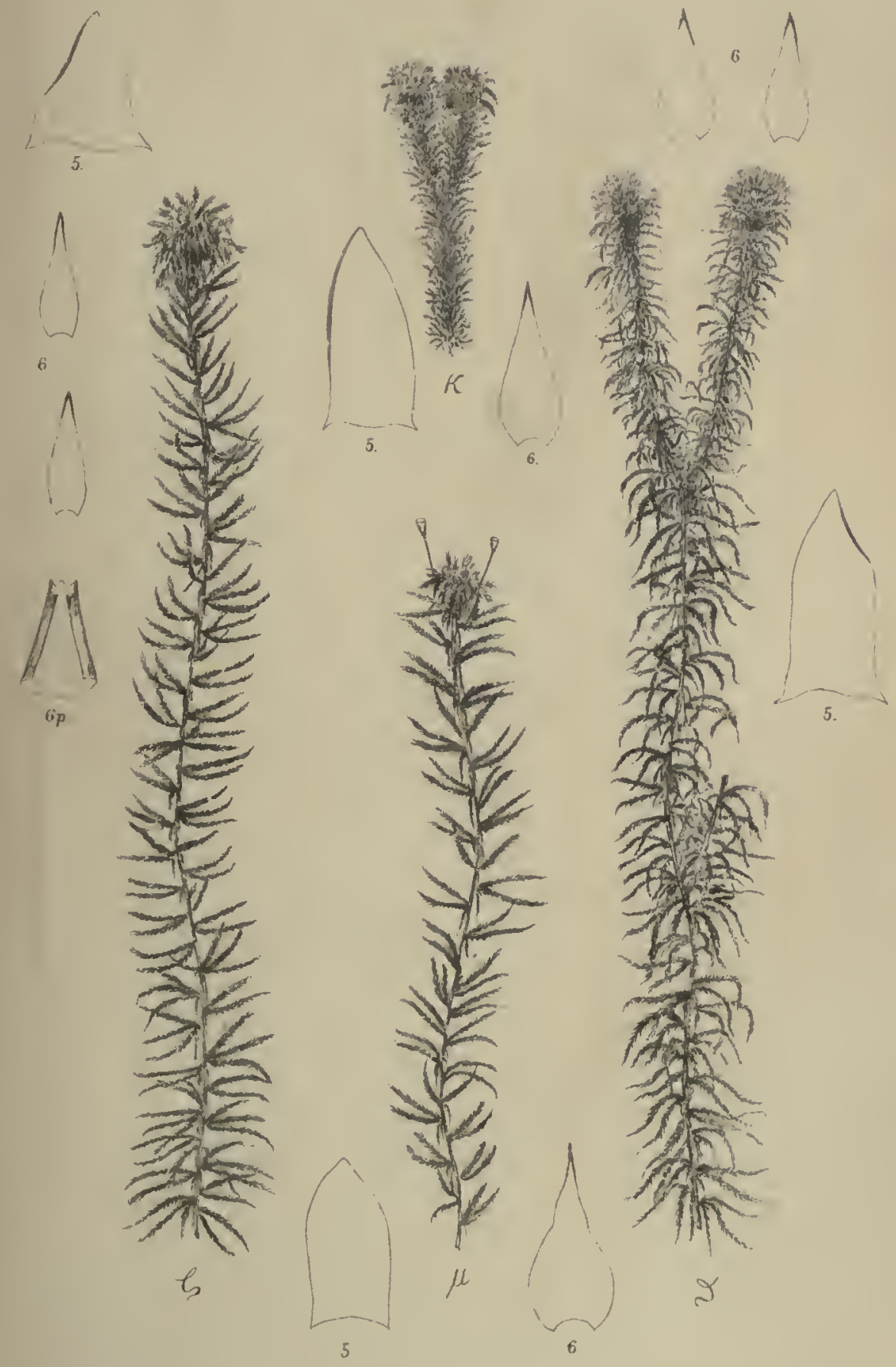



PLATE XXII. 


\section{PLATE XXII.}

\section{Sphagnum Wulfil, Girgens.}

FIG. a.-Fertile plant. FIG. I.-Part of stem and branch fascicle.

"3.-Fruit and perichætium. FIG. 4.-Bract from same.

" 5.-Stem leaves. FIG. 5 a a.-Areolation of apex. FIG. 5ab.-Ditto of basal wing.

"6.-Leaves from middle of a divergent branch. FIG. 6p.- Point of same. FIG. 6c.-Cell from middle $\times 200$. FIG. $6 x$.-Transverse section, 'from upper part, "from lower part.

" 7.- Basal intermediate leaf.

" 8.-Leaf from a pendent branch.

"9x.-Part of section of stem.

" so.-Part of a branch denuded of leaves. 
PI XXI!

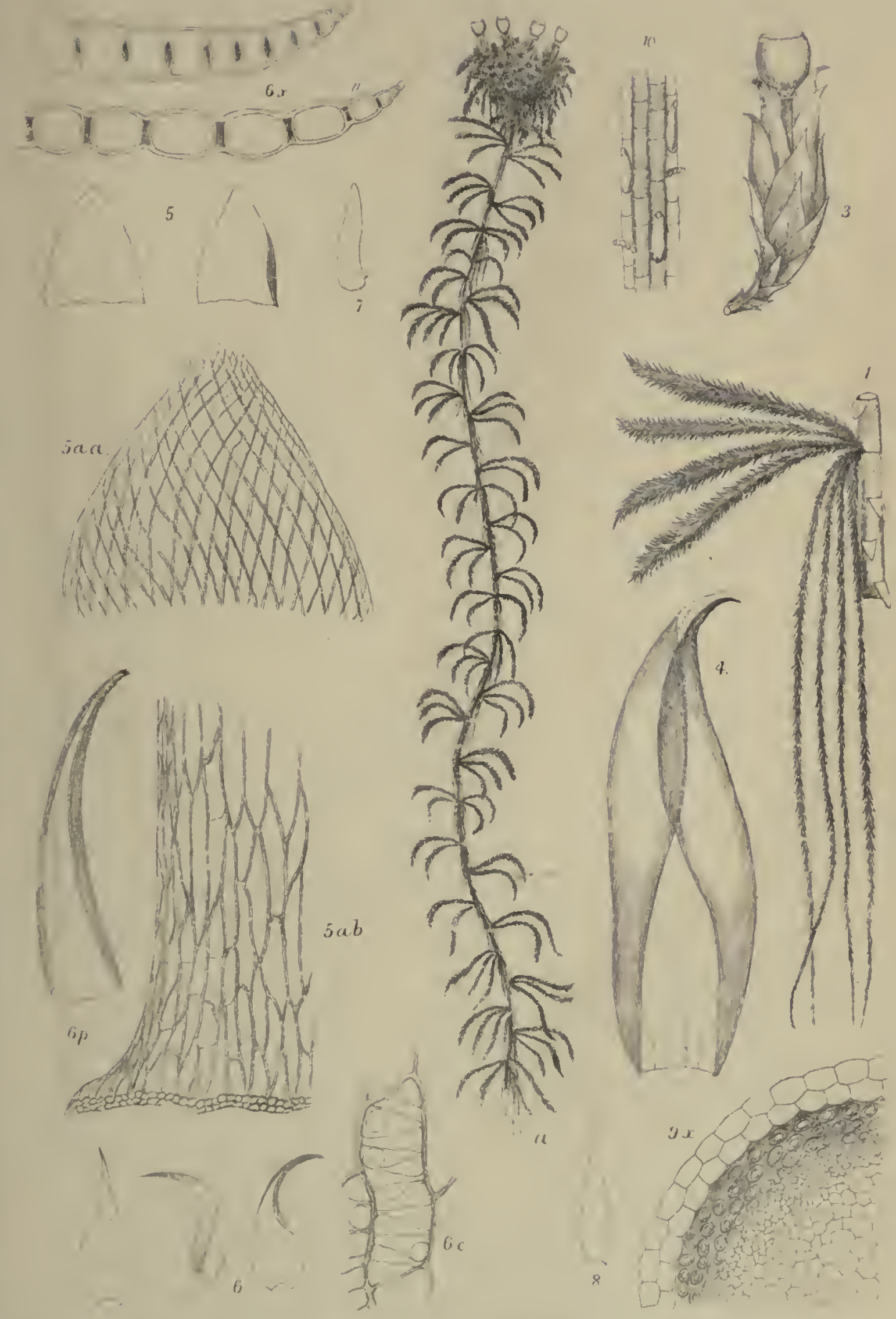



PLATE XXIII. 


\section{PLATE XXIII.}

\section{Sphagnum Lindbergir, Schimp.}

FIG. a.-Fertile plant. FiG. 1.-Part of stem and branch fascicle.

" 3.-Fruit and perichætium. FIG. 4.-Bract from same.

" 5.-Stem leaves. FIG. 5a a.-Areolation of apex $\times 60$. Fig. 5ab.-Ditto of basal wing.

"6.-Leaves from middle of a divergent branch. FIG. 6p. - Point of same. Fic. $6 x$. -Transverse section. Fig. $6 c$ - -Cell from middle $\times 200$.

"7.-Basal intermediate leaf. FIG. $9 x$. Part of section of stem. Fig. 10.-Part of a branch denuded of leaves. 

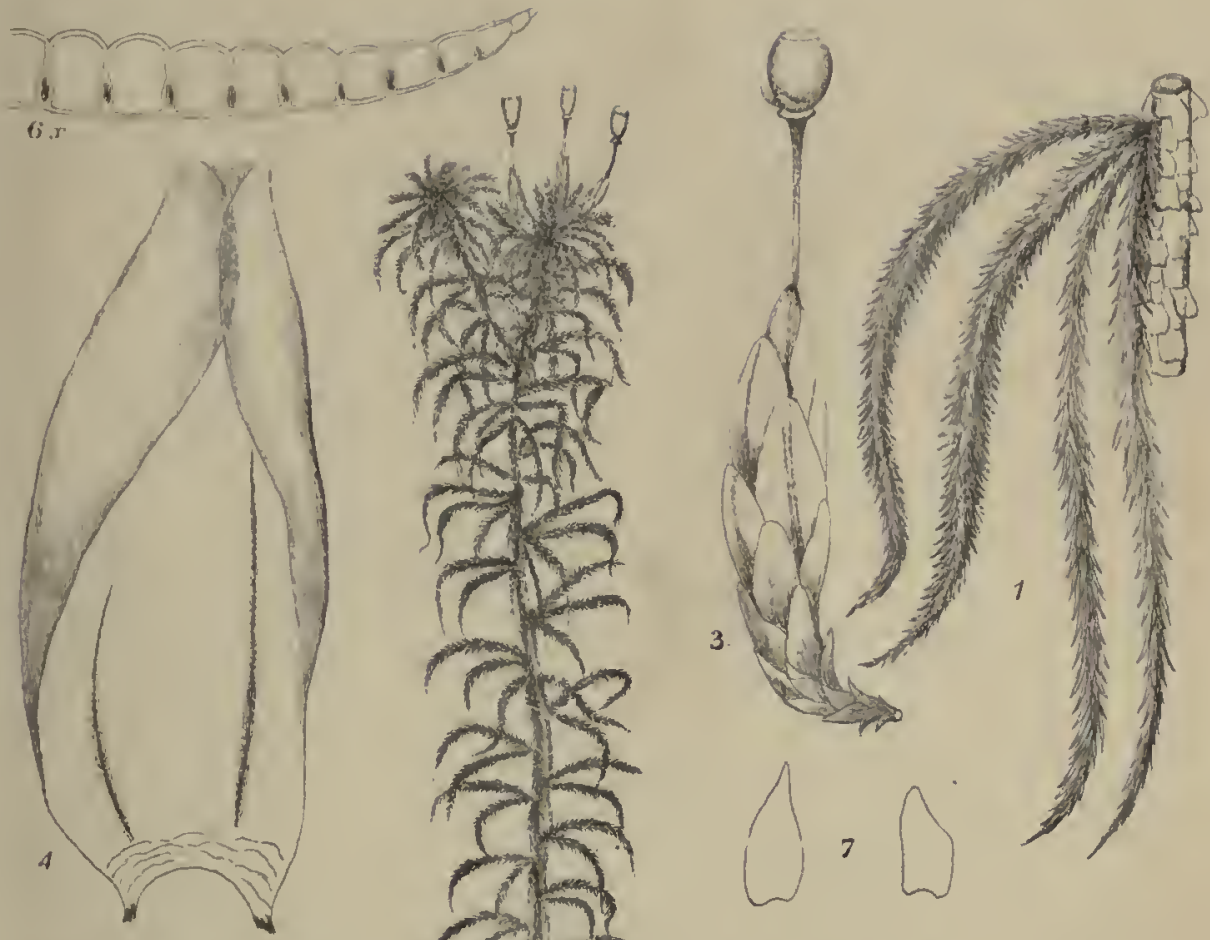

Wriving WMEMNA
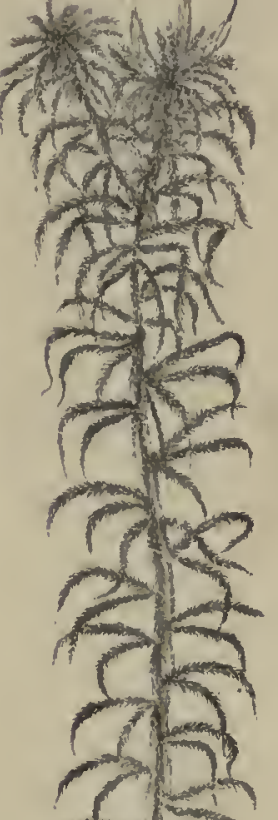

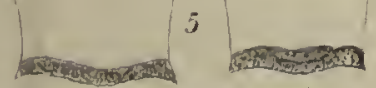

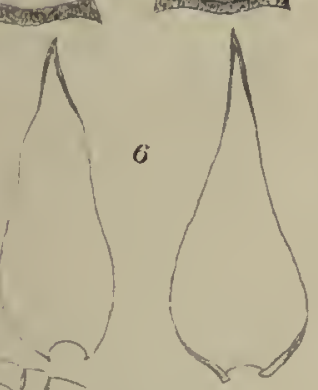

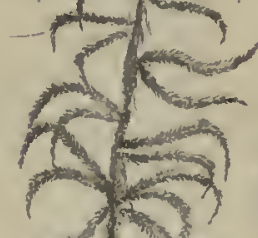

mand 1703 ina.

(4)

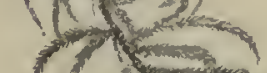

तार

(1) 1

ing

(1) $(1)$

(1)

in

$x+y-2 x^{2}$

ximatio ip

Nind

op.

c 11

(1)

1.
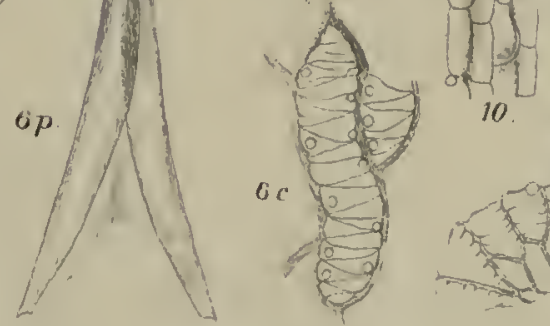

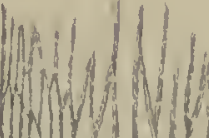
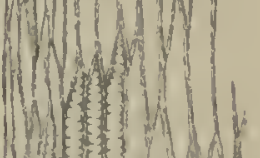

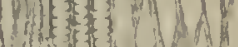
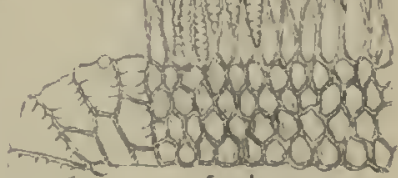

$5 a b$ 



\section{PLATE XXIV.}




\section{PLATE XXIV.}

\section{Sphagnum intermedium, Hoffm.}

FIG. a.-Female plant. Fig. $a$ \$.-Part of male plant.

1. - Part of stem with branch fascicle.

"2.-Male inflorescence. FIG. 26.-Bract with antheridium.

"3.-Perichætium and fruit. FIG. 4.-Bract from same.

" 5.-Stem leaf. FIG. $5 a$ a.-Areolation of apex of same. FIG. $\beta$ 5.-Stem leaf of var. riparium.

"6.-Leaf of divergent branch. FIG. 6',-Same in a dry state. FIG. 6x.-Section. FIG. 6p.-Point of same. FIG. 6c.-Cell from middle $\times 200$.

"7.-Basal intermediate leaves. FIG. 8.-Leaf from a pendent branch.

" 9x.-Part of section of stem. Fig. I0.-Part of a branch denuded of lcaves. 


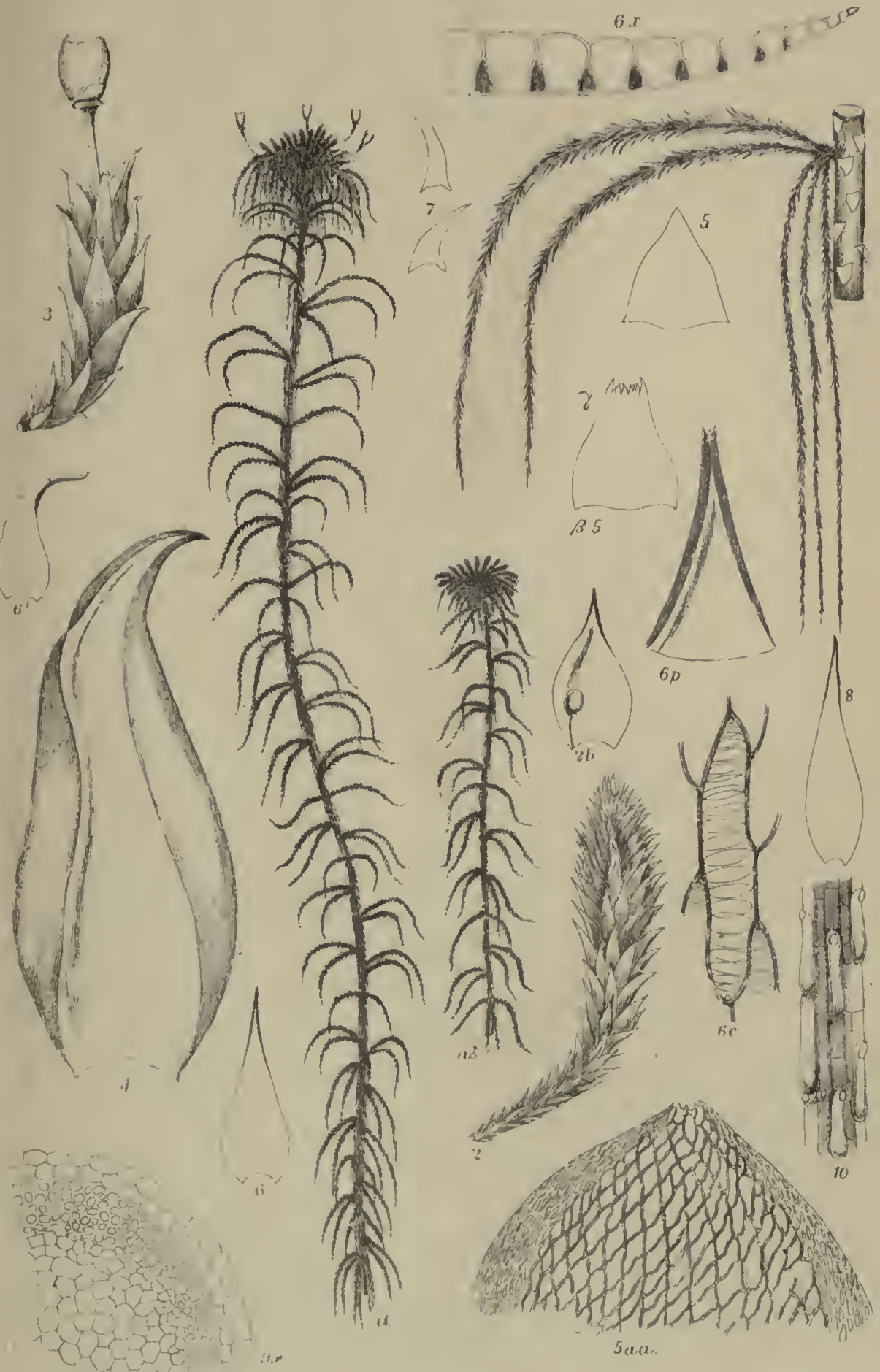



PLATE XXV. 


\section{PLATE XXV.}

\section{SPHAGNUM INTERMEDIUM Vars.}

FIG. $\beta$.-Var. riparium (speciosum), from Russow. FIG. 5.-Stem leaf. FIG. 6.-Branch leaf and apical cells.

" $\beta^{*}$.-Ditto from Old Trafford Moor (Hunt, in Kew Herb.). FrG. 5.-Stem leaf. FIG. 6.-Branch leaf.

". -Var. pulchrum.

" 5.-Stem leaf with its point and a hyaline cell.

"6.-Branch leaf. Fig. 6p.--Point of same. 


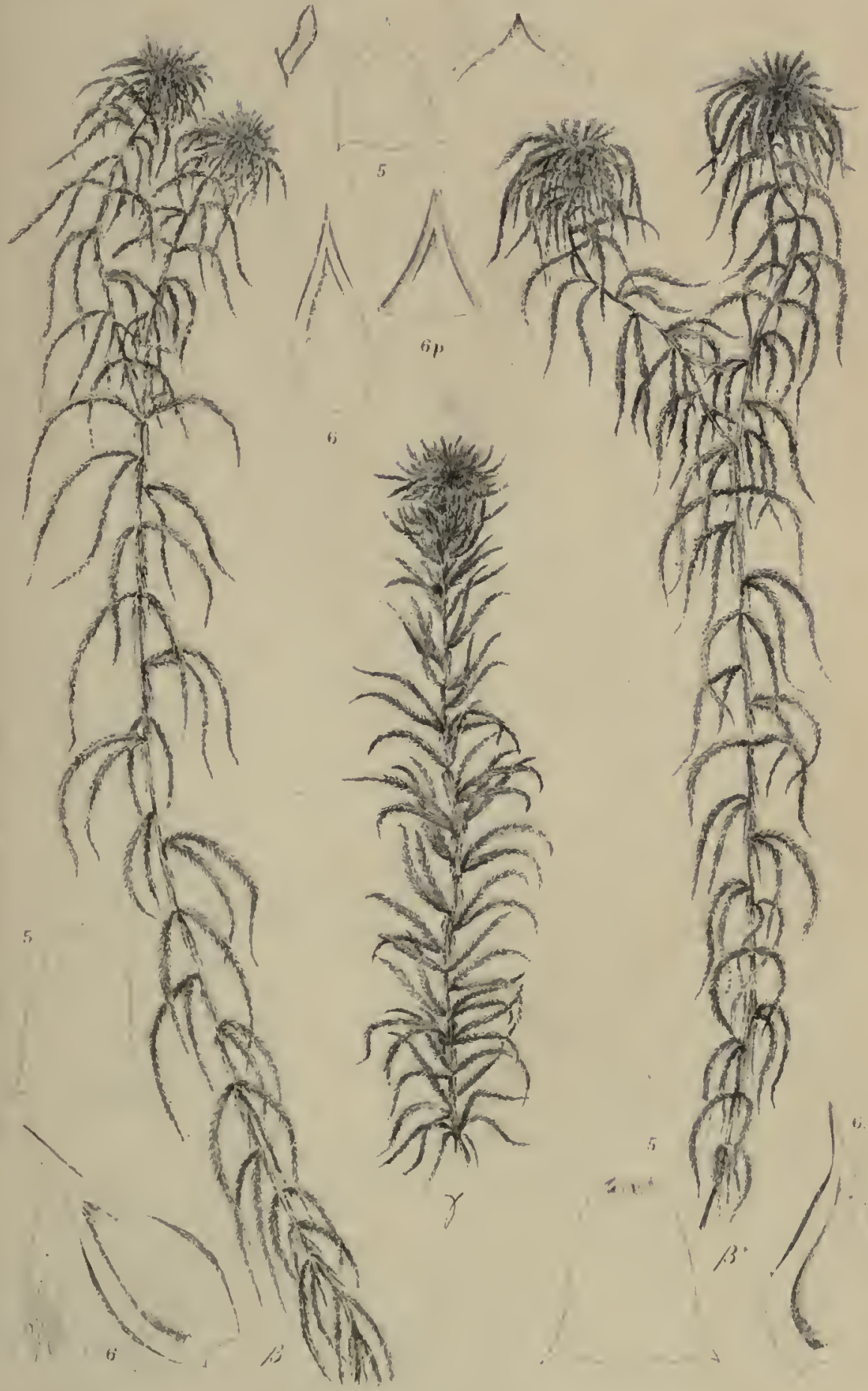





\section{PLATE XXVI.}

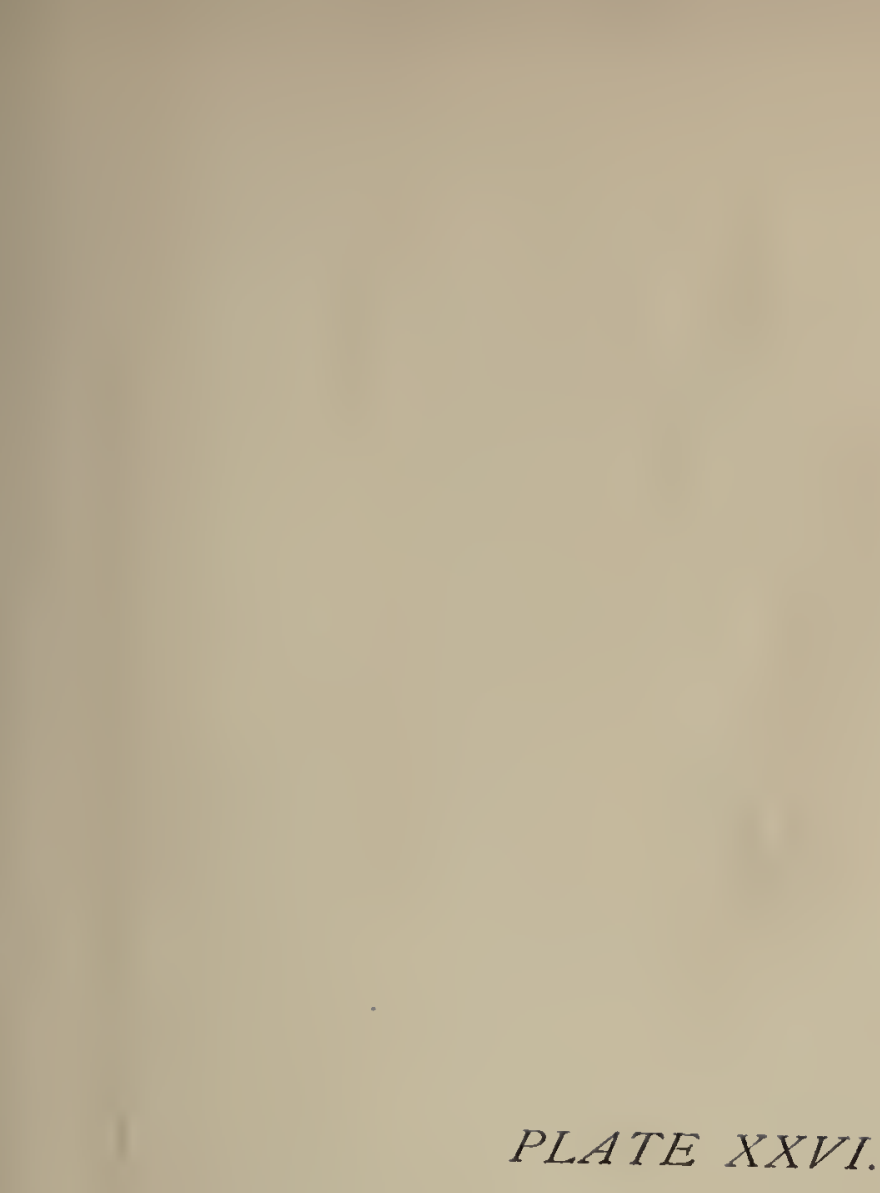$$
\text { - }
$$ 


\section{PLATE XXVI.}

\section{Sphagnum cuspidatum, Ehrhart.}

Fig. a.-Female plant. FiG. $a$ s.-Male plant.

"1.-Part of stem with branch fascicle.

"26.-Bract with antheridium.

" 4.-Perichætial bract.

" 5.-Stem leaves. FIG. 5 a a.-Arcolation of apex.

$"$ 6.-Branch leaves. Fig. 6x.-Section. Fig. 6p.-Point of same.

"6c.-Cell from middle $\times 200$.

"7.-Basal intermediate leaf.

$n$ 9x.-Part of section of stem.

"B.-Var. falcatum, form hypnoides.

". .-Var. plumosum. FIG. $\gamma 6 .-$ Branch leaf of same.

"68.-Branch leaf of var. Torreyi. 


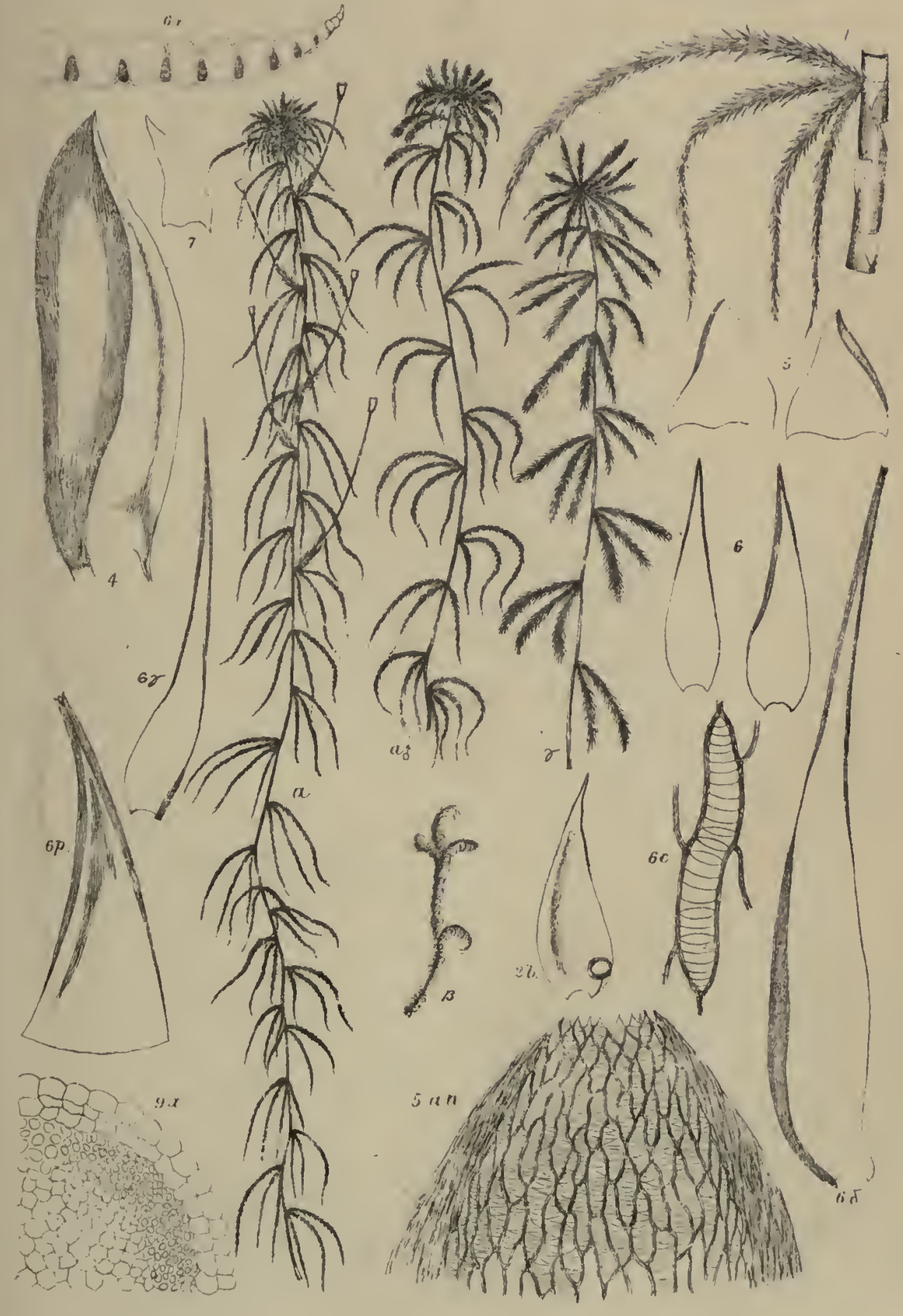



PLATE XXVII.

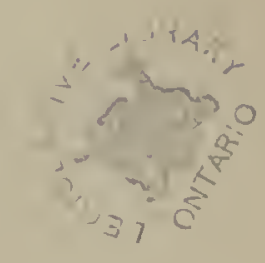




\section{PLATE XXVII.}

\section{SPHAGNUM CUSPIDATUM Vars.}

FIG. 8.-Var. brevifolium.

"5.-Stem leaves. FIG. 5a.-Apex of same.

"6.-Branch leaves. Fic. 6p.-Point of same.

" є.-Var. Torreyi.

"5.-Stem leaf.

"6.-Branch leaf. FIG. 6p.-Point of same. 


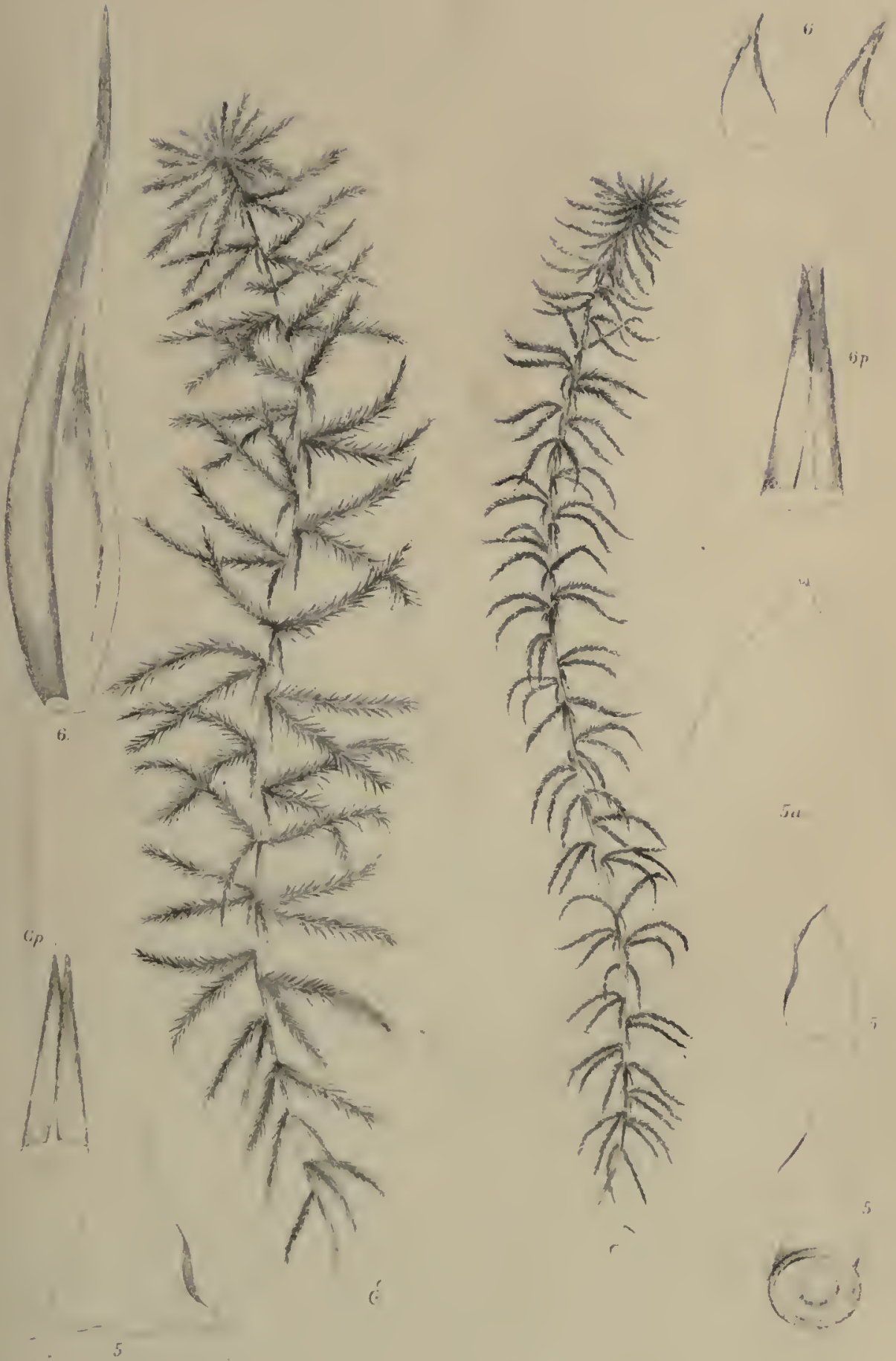



PLATE XXVIII. 


\section{PLATE XXVIII.}

\section{Sphagnum Pylaier, Bridel.}

FIG. a.-From a specimen in Austin's collection.

" I.-Part of sten with a divergent branch.

" 3.-Pcrichxtium with the inmersed operculate capsule

"3c.-Empty capsule. FIG. 4.-Perichætial bract.

" 5.-Stem leaves. FIG. 5 a a.-Areolation of apex of same.

" 6.-Branch leaves. FIG. 6x.-Section. FIG. 6p.-Point of same.

, 6c.-Cell from niddle $\times 200$.

"9x.-Part of scction of sten.

"10.-Part of a branch denuded of leaves.

" $\beta .-$ Var, sedoides, from Sullivant and Lesquereux's collection.

" $\beta$ 5.-Stem leaves. FIG. $\beta$ 5x.-Section of same. 


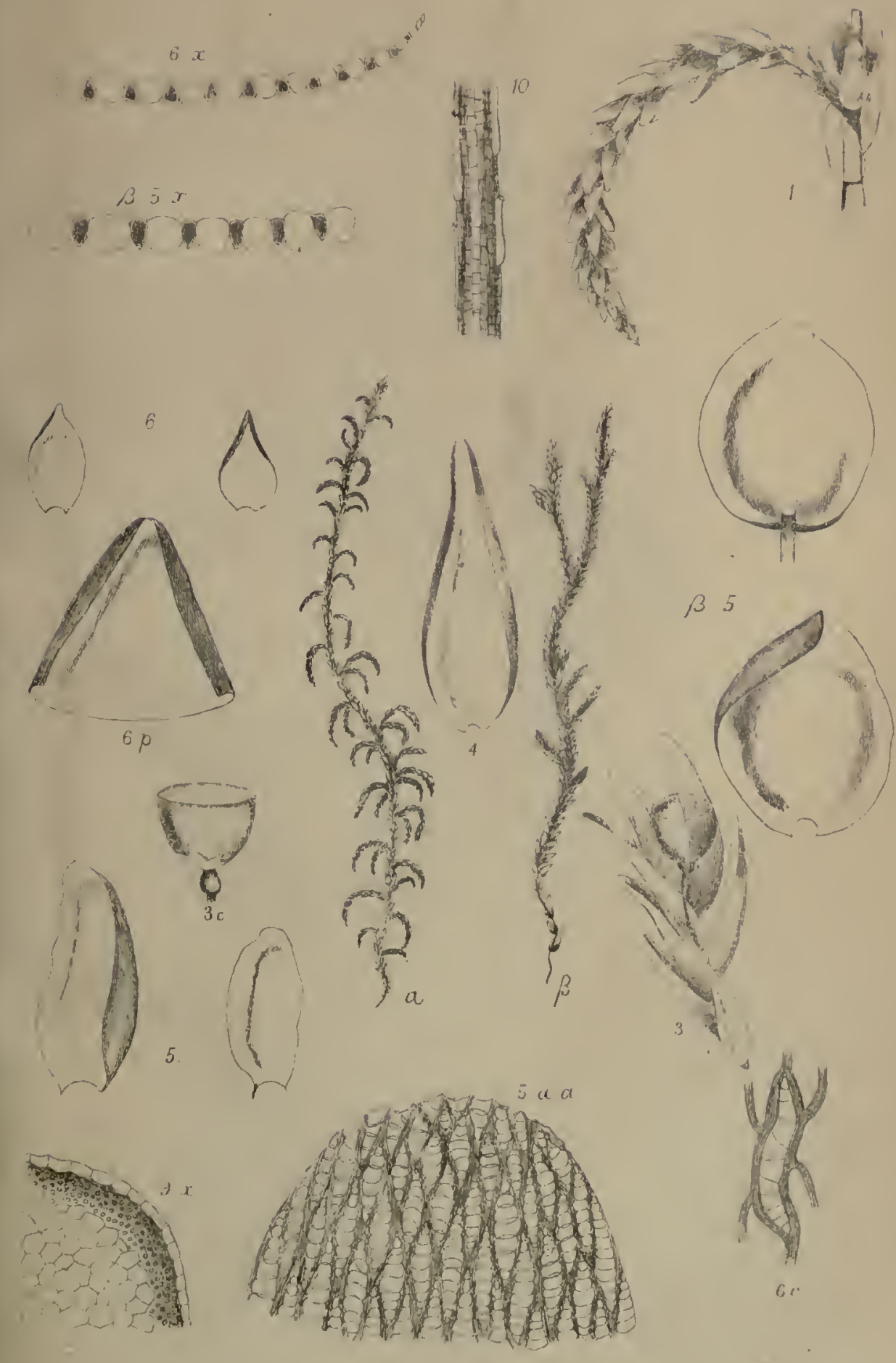



PLATE XXIX. 


\section{PLATE XXIX.}

\section{Sphagnum Macrophyllum, Bernh.}

FIG. a.-Fertile plant, from Drummond's collection.

"4.-Perichætial bract. FIG. $4 p$.-Point of same.

"5.-Stem leaves. Fig. 5 a a.-Areolation of apex of same.

"6. -Leaves from middle of a branch. Fig. 6p.-Point of same. Fig. 6x.-Section. FIG. $6 c_{0}$-Cell from middle $\times 200$. Fig. 66 . - Leaves from base of the same branch.

"9x.-Part of section of stem.

" I0.-Part of a branch denuded of leaves. 


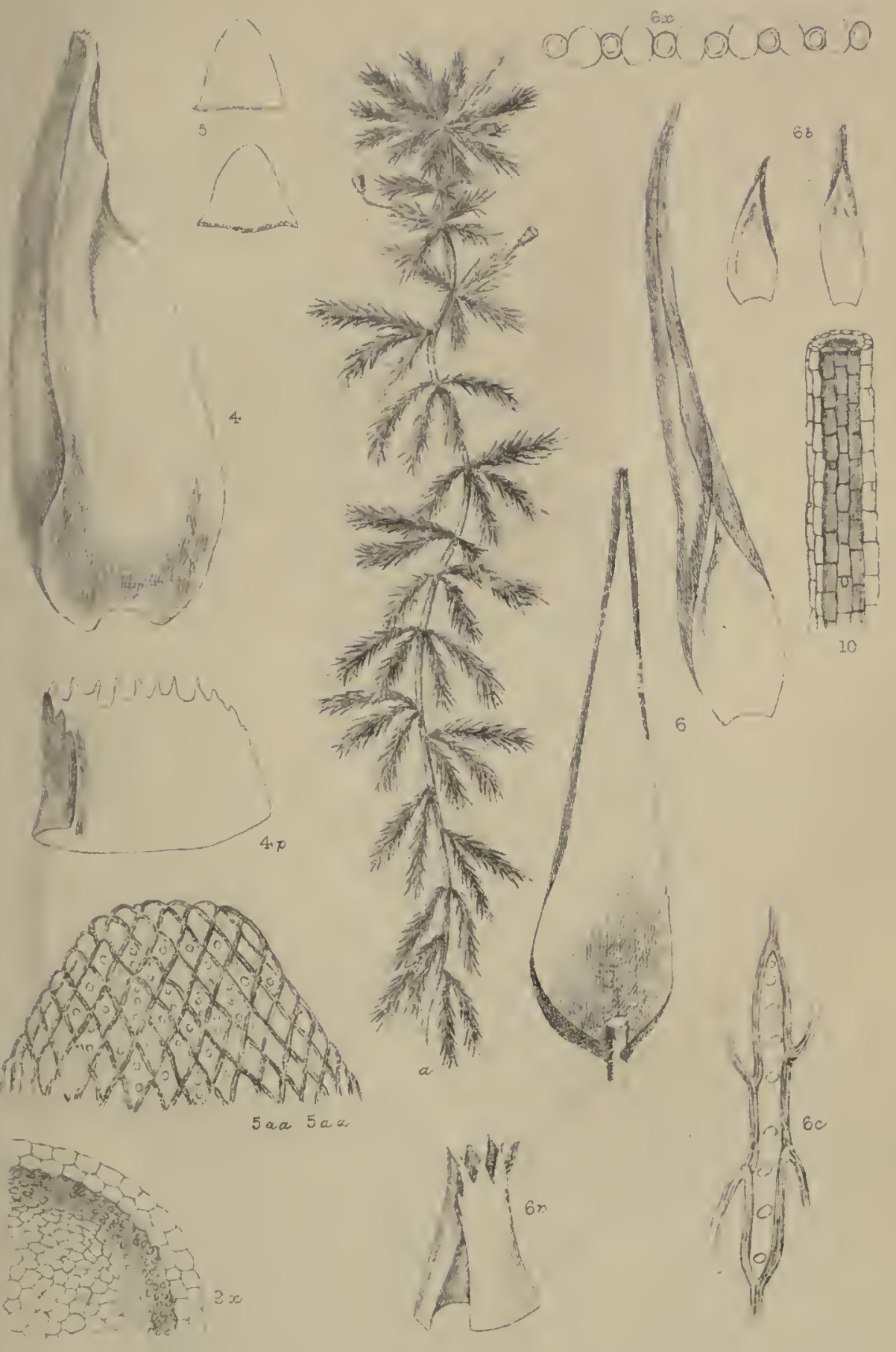

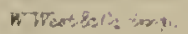





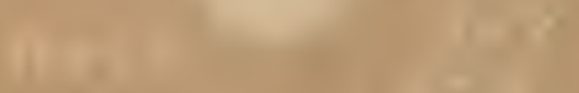

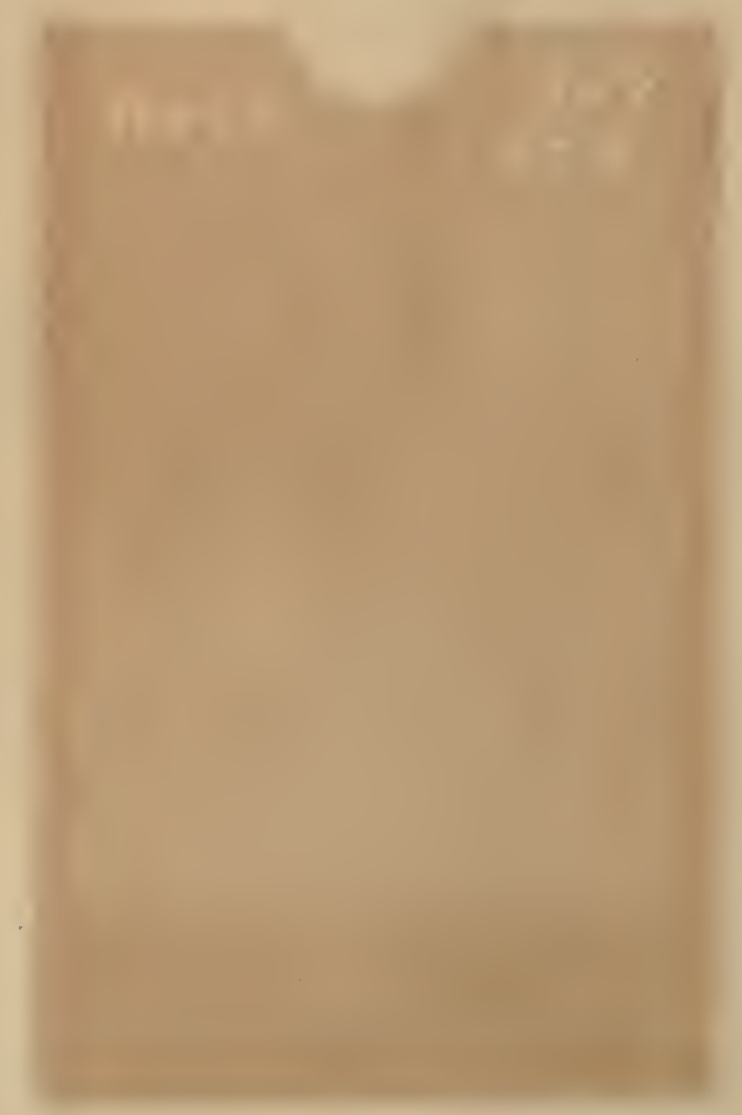


PLEASE DO NOT REMOVE CARDS OR SLIPS FROM THIS POCKET

\section{UNIVERSITY OF TORONTO LIBRARY}

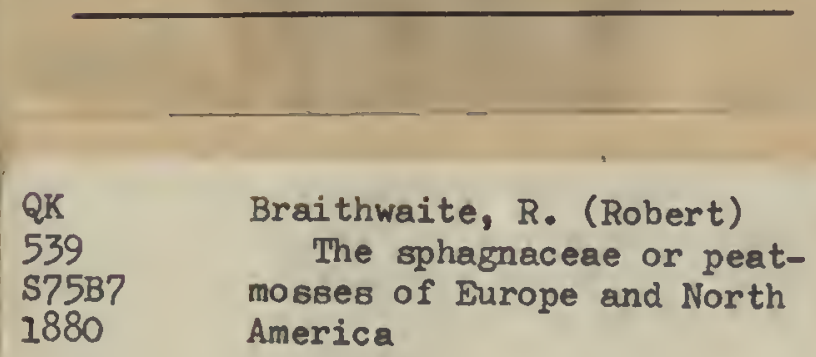

BioMed 


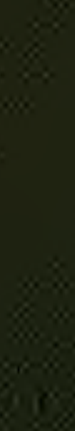

$8 \times x+10$

3 